Aus dem Institut für Pathologie

(Prof. Dr. med. P. Ströbel)

der Medizinischen Fakultät der Universität Göttingen

\title{
One-carbon metabolism in lung
}

cancer

\author{
INAUGURAL-DISSERTATION \\ zur Erlangung des Doktorgrades \\ der Medizinischen Fakultät der \\ Georg-August-Universität zu Göttingen
}

\author{
vorgelegt von \\ Sha Yao \\ aus
}

Changsha, China

Göttingen 2020 
Dekan:

\section{Betreuungsausschuss}

Betreuer/in:

Ko-Betreuer/in:

\section{Prüfungskommission}

Referent/in:

Ko-Referent/in:

Drittreferent/in:

Datum der mündlichen Prüfung:
Prof. Dr. med. W. Brück

Prof. Dr. med. P. Ströbel

Prof. Dr. med. V. Ellenrieder

Prof. Dr. med. P. Ströbel 


\section{Table of Contents}

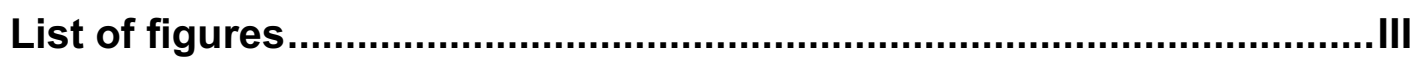

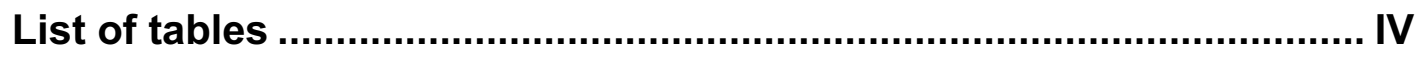

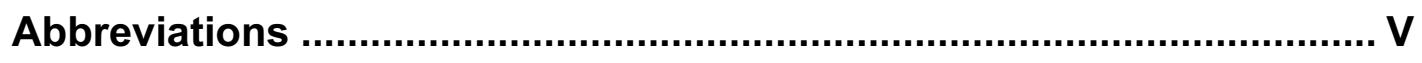

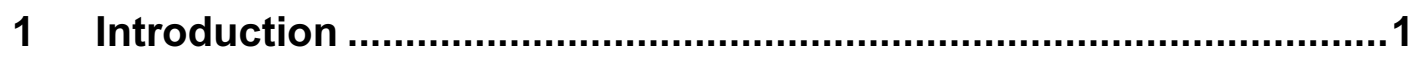

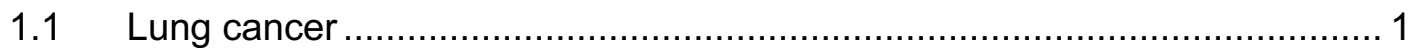

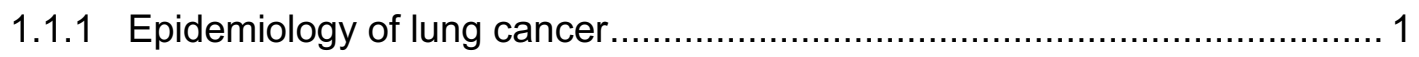

1.1.2 Classification of lung cancer ..............................................................

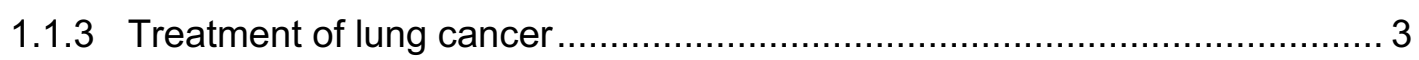

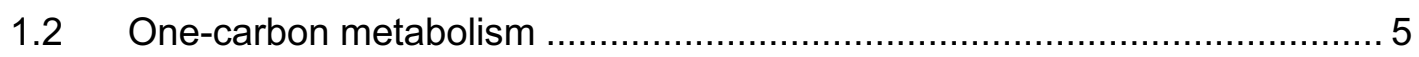

1.2.1 One-carbon metabolism in cancer .................................................... 5

1.2.2 One-carbon metabolism in cancer therapy .............................................. 7

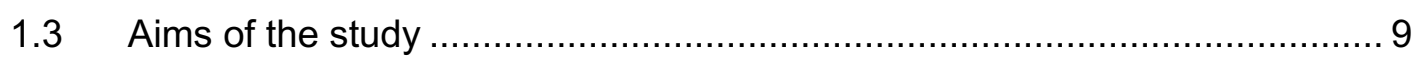

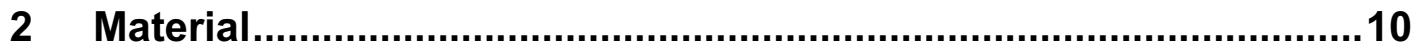

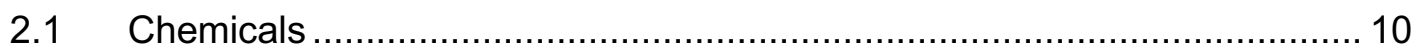

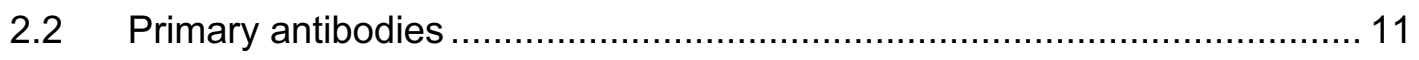

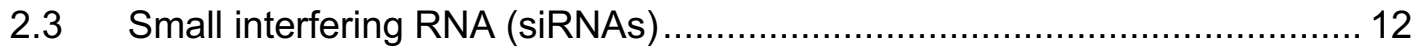

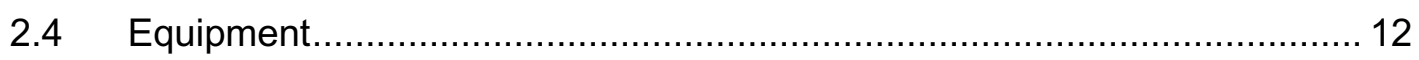

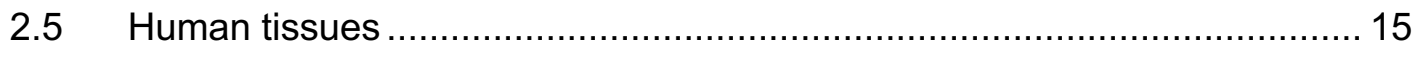

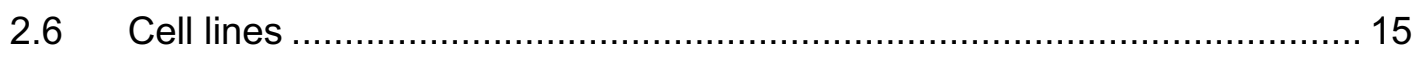

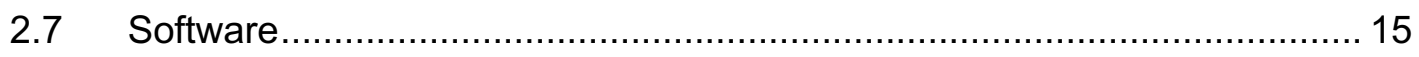

2.8 Laboratory made solutions .................................................................. 16

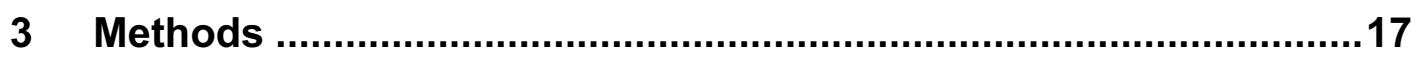

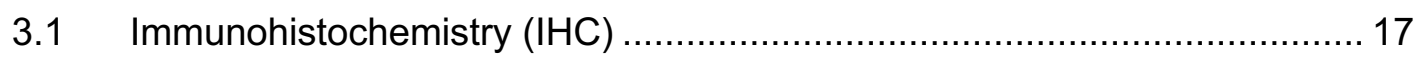

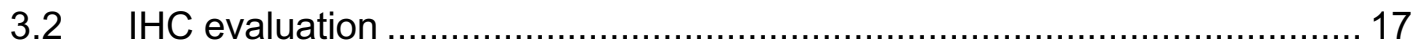

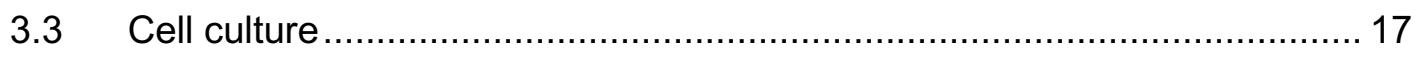

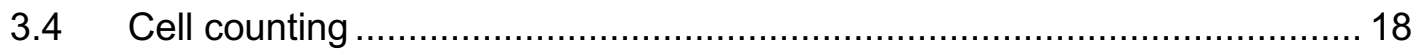

3.5 Protein isolation and western blot analysis .......................................... 18

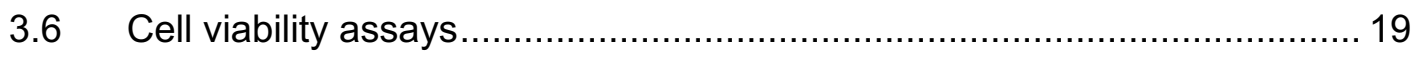

3.7 siRNAs transfection ........................................................................... 19 
3.8 Statistical analyses 20

4 Results 21

4.1 Expression of one-carbon metabolism enzymes in human lung cancer samples 21

4.1.1 Expression of PGDH3 in human lung cancer samples 22

4.1.2 Expression of SHMT2 in human lung cancer samples. 24

4.1.3 Expression of MTHFD2 in human lung cancer samples. 27

4.1.4 Expression of MTHFD1 in human lung cancer samples. 28

4.1.5 Expression of TYMS in human lung cancer samples. 31

4.2 Expression of one-carbon metabolism enzymes in lung cancer cell lines.. 33

4.2.1 PGDH3 enzyme in human lung cancer cell lines. 33

4.2.2 SHMT2 enzyme in human lung cancer cell lines. 36

4.2.3 MTHFD2 enzyme in human lung cancer cell lines. 40

4.2.4 MTHFD1 enzyme in human lung cancer cell lines. 44

4.2.5 TYMS enzyme in human lung cancer cell lines. 48

4.3 Association between one-carbon metabolism enzymes and cytotoxic responsiveness to cisplatin and pemetrexed in lung cancer cell lines.

4.3.1 Correlation of one-carbon metabolism proteins expression with cisplatin or pemetrexed sensitivity in human AC cell lines.

4.3.2 Correlation of one-carbon metabolism proteins expression with cisplatin or pemetrexed sensitivity in human SQCLC cell lines.

4.3.3 Correlation of one-carbon metabolism proteins expression with cisplatin or pemetrexed sensitivity in human SCLC cell lines. 59

5 Discussion

6 Summary

$7 \quad$ Reference 


\section{List of figures}

Figure 1: Distribution of cases and deaths for the three most common cancers in 2018 for both sexes.

Figure 2: Histological and molecular subtypes of NSCLC................................ 3

Figure 3: One-carbon metabolism in cancer cells............................................ 6

Figure 4: The one-carbon metabolism enzymes (highlighted) in cancer cells ....... 21

Figure 5: Prognostic significant of expression PGDH3 protein in lung cancer....... 24

Figure 6: Expression of SHMT2 protein in lung cancer ................................... 26

Figure 7: Prognostic significant of expression MTHFD2 protein in lung cancer .... 28

Figure 8: Expression of MTHFD1 protein in lung cancer. ................................... 30

Figure 9: Expression of TYMS protein in lung cancer........................................ 32

Figure 10: Expression of PGDH3 in human lung cancer cell lines ........................ 34

Figure 11: Knockdown of PGDH3 significant reduced cell proliferation of lung AC

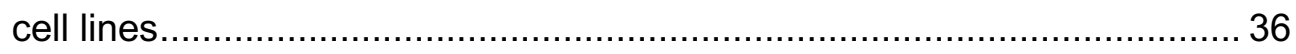

Figure 12: Expression of SHMT2 in human lung cancer cell lines....................... 38

Figure 13: Knockdown of SHMT2 significant reduced cell proliferation of lung AC

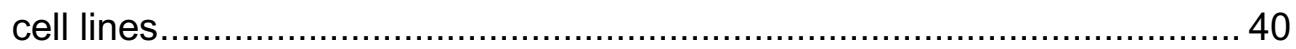

Figure 14: Expression of MTHFD2 in human lung cancer cell lines ..................... 42

Figure 15: Knockdown of MTHFD2 significant reduced cell proliferation of lung

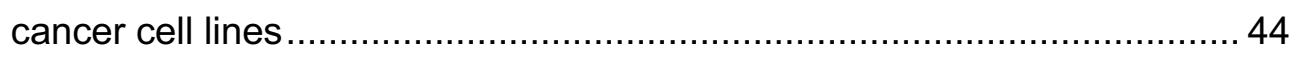

Figure 16: Expression of MTHFD1 in human lung cancer cell lines .................... 46

Figure 17: Knockdown of MTHFD1 significant reduced cell proliferation of lung

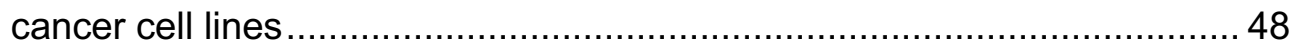

Figure 18: Expression of TYMS in human lung cancer cell lines.........................50

Figure 19: Knockdown of TYMS significant reduced cell proliferation of lung cancer cell lines.

Figure 20: Correlation of one-carbon metabolism proteins expression with cisplatin or pemetrexed sensitivity in AC cell lines. 56

Figure 21: The expression of one-carbon metabolism protein is not associated with chemoresistance in SQCLC cell lines 59

Figure 22: Correlation of one-carbon metabolism proteins expression with cisplatin or pemetrexed sensitivity in SCLC cell lines 


\section{List of tables}

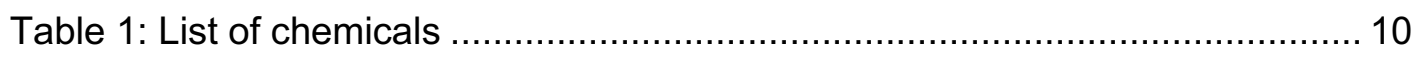

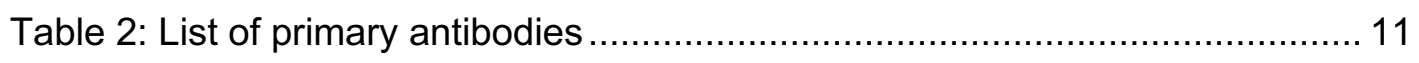

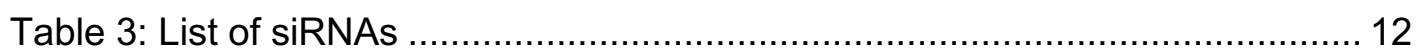

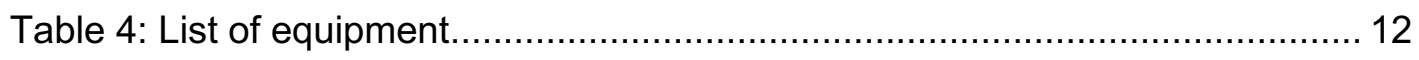

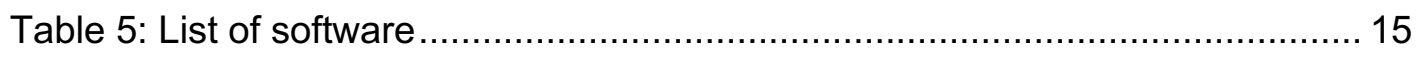

Table 6: List of laboratory buffer and solution ..................................................... 15

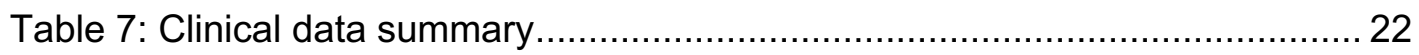

Table 8: IC50 values of cisplatin and pemetrexed in AC cell lines ....................... 54

Table 9: IC50 values of cisplatin and pemetrexed in SQCLC cell lines .................57

Table 10: IC50 values of cisplatin and pemetrexed in SCLC cell lines..................60 


\section{Abbreviations}

AC

Akt

ALL

ALK

ATCC

CRC

$c-M Y C$

$\mathrm{ddH}_{2} \mathrm{O}$

DHFR

DNA

dTMP

dUMP

EGFR

ERK

EWS

EDTA

FBS

FDA

GARFT

IC50

IHC

MTHFD2

NADPH

$\mathrm{NCCN}$

NSCLC

PBS

PGDH3

$\mathrm{PI}(3) \mathrm{K}$

PRPP

PSAT1
Adenocarcinoma

Protein kinase B

Acute lymphoblastic leukemia

Anaplastic lymphoma kinase

American type culture collection

Colorectal cancer

Cellular myelocytomatosis oncogene

Double distilled water

Dihydrofolate reductase

Deoxyribonucleic acid

Deoxythymidine monophosphate

Deoxyuridine monophosphate

Epidermal growth factor receptor

Extracellular signal regulated kinase

Ewing's sarcoma

Ethylenediaminetetraacetic acid

Fetal bovine serum

Food and drug administration

Glycinamide ribonucleotide formyltransferase

Half maximal inhibitory concentration

Immunohistochemistry

Methylenetetrahydrofolate dehydrogenase 2

Nicotinamide adenine dinucleotide phosphate hydrogen

National comprehensive cancer network

Non-small-cell lung cancer

Phosphate buffered saline

3-phosphoglycerate dehydrogenase

Phosphatidylinositol-4,5-biphosphate 3-kinase

Phosphoribosyl pyrophosphate

Phosphoserine aminotransferase 1 


\begin{tabular}{ll} 
PSPH & Phosphoserine phosphatase \\
PVDF & Polyvinylidene difluoride \\
RAS & Rat sarcoma \\
RNA & Ribonucleic acid \\
RNR & Ribonucleotide reductase \\
RT & Room temperature \\
RTK & Receptor tyrosine kinase \\
SCLC & Small cell lung cancer \\
SEM & Standard error of mean \\
SHMT2 & Serine hydroxymethyltransferase 2 \\
SQCLC & Squamous cell lung carcinoma \\
TBST & Tris buffered saline with Tween 20 \\
THF & Tetrahydrofolate \\
Tris & Tris (hydroymethyl) aminomethane \\
TYMS & Thymidylate synthase \\
WHO & World health organization \\
3-PG & 3-phosphoglucerate \\
5-FU & 5-fluorouracil \\
\hline
\end{tabular}




\section{Introduction}

\subsection{Lung cancer}

\subsubsection{Epidemiology of lung cancer}

According to the cancer report 2019, there are 606,880 Americans would die from cancer, which means that nearly 1,700 deaths per day. The greatest number of deaths arises from cancers among men and women is lung cancer (Siegel et al. 2019). Lung cancer is still the most common cancer and the leading cause of cancer direct or indirect related mortality worldwide (Brambilla and Travis 2014; Bray et al. 2018). The International agency for research reported more than 2 million new lung cases (11.6\% of the total new cancer cases) and more than 1.8 million deaths (18.4\% of the total cancer deaths) worldwide in 2018 (Figure 1) (Bray et al. 2018; Ferlay et al. 2019). The combined five-year survival rate for all stages is only $18.0 \%$ (Siegel et al. 2018).

Incidence

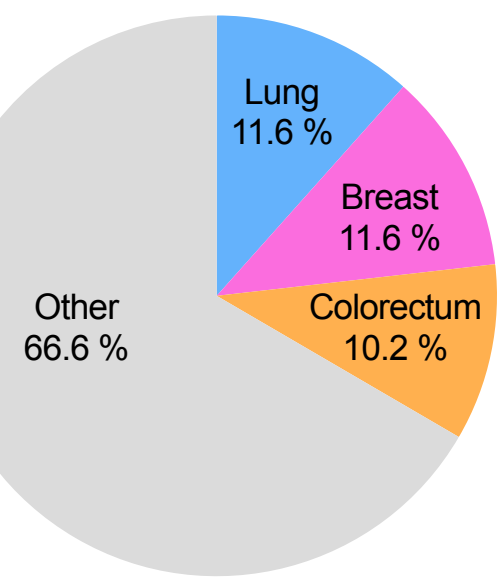

18.1 million new cases
Mortality

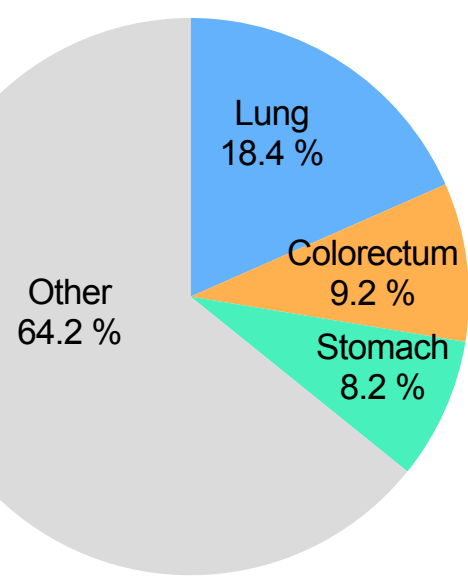

9.6 million deaths

Figure 1: Distribution of cases and deaths for the three most common cancers in 2018 for both sexes. 


\subsubsection{Classification of lung cancer}

Lung cancer is confirmed and diagnosed by a histological or cytological approach (Nizzoli et al. 2011; Rekhtman et al. 2011), and can be defined into two major types: non-small-cell lung cancer (NSCLC, $85 \%$ of all cases) and small cell lung cancer (SCLC, $15 \%$ of all cases) according to the World Health Organization (WHO) classification (Duruisseaux and Esteller 2018; Marx et al. 2015; Travis et al. 2015). This classification reflects the clinical differences among different types of lung cancer, including clinical manifestations, the rate of metastasis and the effectiveness of treatment. Moreover, NSCLCs are further subdivided into lung adenocarcinoma (AC) ( 45.0\%) and squamous cell lung carcinoma (SQCLC) ( 25.0 \%) (Figure 2 (Politi and Herbst 2015; Skoulidis and Heymach 2019; Travis et al. 2015)).

The new classification of lung cancer reflects the better understanding of the molecular characteristics of lung cancer and individual therapy or multi-therapy (Skoulidis and Heymach 2019). For example, mutations of epidermal growth factor receptor (EGFR) or anaplastic lymphoma kinase (ALK) have been shown to be sensitive to targeted therapies such as tyrosine kinase inhibitors (Nakaoku et al. 2014; Shim et al. 2015; Takeuchi et al. 2012). Approximately $75.0 \%$ of all lung adenocarcinoma harbor genetic alterations that lead to promote a series of aberrant signaling pathway such as receptor tyrosine kinase (RTK)/RAS/RAF axis (Cancer Genome Atlas Research 2014) (76.0 \% of cases), p53 pathway alteration $(63.0 \%)$, and alteration of cell cycle regulators $(64.0 \%)$. These targetable genetic alterations hold the promise to be used as therapeutic targets. In SQCLC, although researches show abnormal pathway including phosphatidylinositol-4,5-biphosphate 3-kinase ( $\mathrm{PI}(3) \mathrm{K})$, rat sarcoma (RAS) and RTK signaling in cancers, related targeted drugs have not been arrived clinical yet so far (Cancer Genome Atlas Research 2014). SCLC is the worst prognosis subtype. Studies have identified SOX2 and fusion RLF-MYCL1 as potential targets, however molecular-targeted agents has not yet been developed (Cancer Genome Atlas Research 2014; George et al. 2015). 


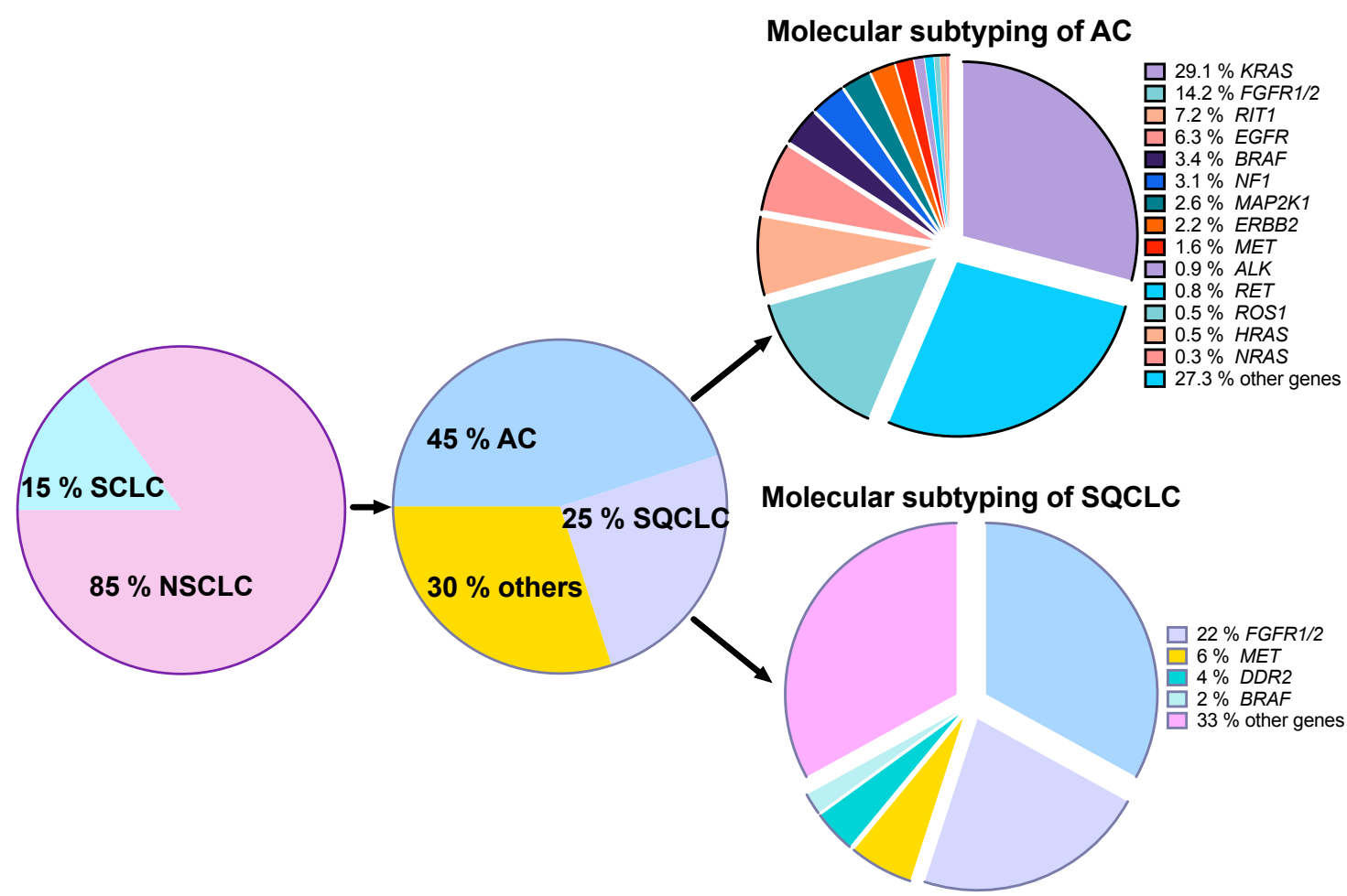

Figure 2: Histological and molecular subtypes of NSCLC. NSCLC: non-small cell lung carcinoma; AC: adenocarcinoma; SQCLC: squamous cell carcinoma.

\subsubsection{Treatment of lung cancer}

Over the last decades, many important discoveries and efforts have been made to improve curative therapies and decrease the mortality of lung cancer. In general, surgery is still considered standard therapy for early-stage NSCLC (Vansteenkiste et al. 2014). However, patients with NSCLC usually present in advanced stages and are unresectable and require systemic treatment. Recent developments have highlighted molecular distinct and therapeutic vulnerabilities in lung cancer subtypes. These findings have led to the development of targeted therapies and immune checkpoint inhibitors.

Molecular targeted therapy and immunotherapy are the most advanced therapeutic methods in recent years (Borghaei et al. 2015; Mok et al. 2009). Although these methods provide more choices and have substantially increased length and quality of life for some patients with lung cancer (Herbst et al. 2016; Kris et al. 2014), the limitations of these therapeutics are obvious. The molecular 
targeted therapy is expensive (Djalalov et al. 2014) and only effective in patients with specific gene mutation (Paez et al. 2004). In the same manner, only some patients with NSCLC benefit from immunotherapy and the effect varies from person to person (Garon et al. 2015; Reck et al. 2016). For patients with SCLC, the chemotherapy or combination with radiotherapy is the primary therapeutic modality on account of few advances in therapeutic options (Okamoto et al. 2007; Takada et al. 2002).

Regardless of histological subtypes and stage of lung cancer, the systemic chemotherapy remains an essential treatment for patients with lung cancer. For early-stage lung cancer, it has been proved that adjuvant cisplatin based chemotherapy could increase improve survival time (Arriagada et al. 2010; Morgensztern et al. 2016; Salazar et al. 2017), and 1-year survival increases in patients with advanced lung cancers using chemotherapy (Paz-Ares et al. 2013; Sandler et al. 2006). According to the American society of clinical oncology and national comprehensive cancer network (NCCN) guidelines, chemotherapy regimens for NSCLC combine two cytotoxic agents in first-line e.g. Pemetrexed and cisplatin is a standard treatment combination for NSCLC (Scagliotti et al. 2008; Schiller et al. 2002).

Pemetrexed is a novel multi-target agent that inhibits hymidylate synthase (TYMS), dihydrofolate reductase (DHFR) and glycinamide ribonucleotide formyltransferase (GARFT) (Adjei 2000; Shih et al. 1997). Cisplatin is a widely used and well-known anticancer drug, which causes deoxyribonucleic acid (DNA) damage, block cell division and induce apoptosis in cancer cells (Dasari and Tchounwou 2014). Although pemetrexed plus cisplatin shows similar efficacy compared to other standard treatment options, the combination of pemetrexed/cisplatin in patients with adenocarcinoma demonstrated a significantly better survival than cisplatin/gemcitabine, as well as better tolerability and good performance (Gadgeel et al. 2011; Paz-Ares et al. 2012; Paz-Ares et al. 2013; Scagliotti et al. 2014; Scagliotti et al. 2008). However, chemotherapy resistance is a major issue in the clinic. Some lung tumors initially response to chemotherapy but then rapidly develop acquired resistance. 


\subsection{One-carbon metabolism}

One-carbon metabolism is a universal metabolic cycle in health and disease and is composed of folate compounds chemical reactions. Furthermore, this pathway is important in nucleic acid synthesis, mitochondrial protein synthesis in, amino acid metabolism, vitamin metabolism (Ducker and Rabinowitz 2017; Shane and Stokstad 1985; Stipanuk 2004; Stover 2004; Tibbetts and Appling 2010).

\subsubsection{One-carbon metabolism in cancer}

One-carbon metabolism includes both the de novo serine synthesis pathway and folate cycles (Ducker and Rabinowitz 2017). First, 3-phosphoglucerate (3-PG) is a metabolite originated from glucose in glycolysis and can be converted into serine by 3-phosphoglycerate dehydrogenase (PGDH3). In addition, PGDH3 can regulate the release of the tetrahydrofolate (THF) into mitochondria (Fell and Snell 1988; Snell 1984). Subsequently, within the mitochondrial first step of folate cycles, the THF is converted to intermediate metabolites, 5, 10-methenylene-THF or 10-formyl-THF, by their enzymes (Hebbring et al. 2012; Snell et al. 1987), the serine methyltrasferases 2 (SHMT2), methylenetetrahydrofolate dehydrogenase 2 (MTHFD2), separately. Then, the 10-formyl-THF from the mitochondria can be regenerated and converted into the 5, 10-methenylene-THF by an enzyme in the cytosol, MTHFD1 (Tibbetts and Appling 2010; Yang and Vousden 2016). Finally, some of the 5, 10-methenylene-THF is directly converted THF, the rest is involved in the thymidylate synthesis catalyzed by an enzyme, thymidylate synthase (Ducker and Rabinowitz 2017). Furthermore, these enzymes play the key role at maintaining a complete oxidative/reductive cycle also in cancer cells including lung cancer (Figure 3 (Ducker and Rabinowitz 2017)). 


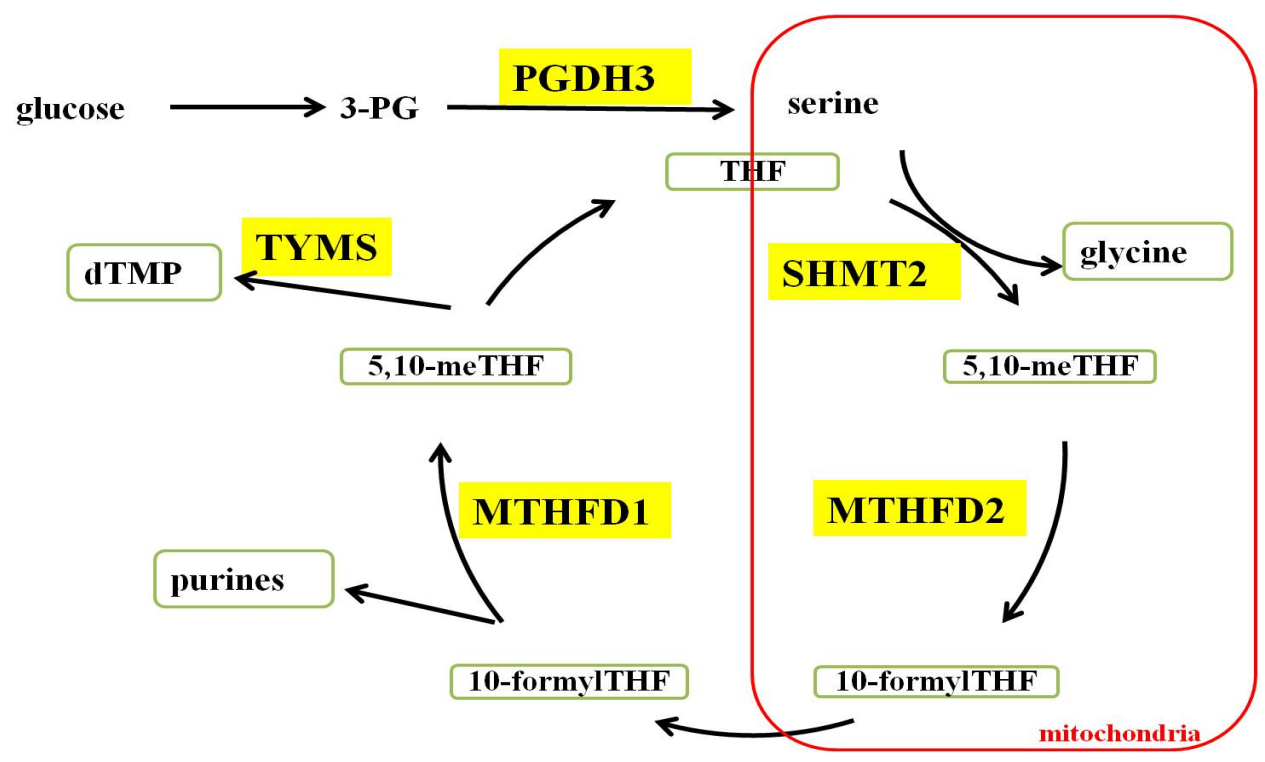

Figure 3: One-carbon metabolism in cancer cells.

Recent studies have identified the de-novo serine synthesis pathway, where the mitochondrial folate metabolism and one-carbon metabolic enzymes are upregulated in cancer cells (Ducker and Rabinowitz 2017; Mehrmohamadi et al. 2014; Newman and Maddocks 2017). These metabolic enzymes play an important role in tumorigenesis and tumor development.

PGDH3 is required for tumorigenesis and proliferation in melanoma and breast cancer cell lines (Locasale et al. 2011; Mullarky et al. 2011; Possemato et al. 2011). Furthermore, studies showed that PGDH3 contributes to cell maintenance, migration and invasion in different cancer including renal cell carcinoma, breast cancer and pancreatic cancer (Samanta et al. 2016; Song et al. 2018; Yoshino et al. 2017).

SHMT2 catalyzes mitochondrial one-carbon metabolism (Ducker and Rabinowitz 2017; Stover and Schirch 1990), is important for tumor growth in various types of cancer such as melanoma, breast cancer, and ovarian carcinoma (Lee et al. 2014) and maintains a compartmentalized one-carbon pathway in mitochondria (Minton et al. 2018).

Nilsson et al. (2014) reported that MTHFD2 amplification and MTHFD2 protein are significantly increased in cancers such as lung cancer, breast cancer and 
colon cancer and MTHFD2 over-expression was shown in proliferating tumors which enhancement growth of cancer cells related with production of excessive one-carbon units for purine synthesis (Christensen and Mackenzie 2008). A study reported that expression of MTHFD2 indicated an increased invasiveness and poor prognosis in cancers including breast cancer, renal cell cancer, and hepatocellular carcinoma (Lehtinen et al. 2013; Liu et al. 2014; Liu et al. 2016; Minton et al. 2018). Knockdown of MTHFD2 impaired cell proliferation and induced differentiation in acute myeloid leukemia (Pikman et al. 2016).

Together, these findings have provided evidence that the one-carbon metabolism pathway is important for oncogenesis in several cancer entities.

\subsubsection{One-carbon metabolism in cancer therapy}

Recently, one-carbon metabolism has been developed a promising molecular target in cancer therapy (Dominguez-Salas et al. 2012; Koseki et al. 2018; Nilsson et al. 2014; Williams 2012). Various traditional cytotoxic chemotherapeutic agents, such as antifolates (e.g. Methotrexate, Pemetrexed, Aminopterin), have been developed to target the one-carbon metabolic pathway. PGDH3 has a role of serine synthesis and is associated with tumor cell proliferation. Inhibition of the serine synthesis pathway by specific inhibitors or relative RNAi highly reduces tumor cell growth (Mullarky et al. 2016; Pacold et al. 2016). For example, targeting PGDH3 reduces breast cancer cell proliferation and inhibits xenograft growth specifically in cell lines with overexpression of PGDH3 (Pacold et al. 2016). However, PGDH3 suppression inhibited proliferation in human breast cancer cells even supplementation with additional serine in media was not able to rescue a capacity of cell growth (Chen et al. 2013; Possemato et al. 2011). This suggests that it may bypass the PGDH3 to provide serine to cancer cells by other mechanisms or pathways. Naturally, residual onecarbon metabolism enzymes including SHMT2, MTHFD2, MTHFD1 and TYMS are novel potential targets for cancer treatment given their important role in cancer (Christensen and MacKenzie 2006; Tedeschi et al. 2015). Studies reported the activity of enzymes of the serine synthesis pathway is increased and expression of SHMTs is also uprelated in cancer cells (Snell and Weber 1986). 5-fluorouracil (5-FU) targets TYMS which blocks availability of thymidylate, 
inhibits DNA replication and induces apoptosis (Longley et al. 2003). Raltitrexed which targets TYMS is used for the treatment of advanced colorectal cancer (Cunningham et al. 1996; Minton et al. 2018). Pemetrexed inhibits multiple folaterequiring enzymes that are involved in the synthesis of nucleotides, including TYMS, SHMTs, GARFT, and DHFR (Daidone et al. 2011; Smith et al. 2000). Moreover, deleterious side effects of chemotherapy drugs in healthy proliferating cells and chemoresistance in cancer cells are an important problem in clinical practice. The selective inhibition of individual one-carbon metabolism enzymes in cancer cells might reduce adverse side effects.

MTHFD2 is a member of MTHFD enzyme family and necessary for nucleotide synthesis. MTHFD2 is widely found in embryonic, non-differentiated tissues and is almost exclusively expressed in cancer cells (Bolusani et al. 2011; Nilsson et al. 2014). One of mitochondrial folate metabolic enzymes, MTHFD2 has paid much attention as a potential therapeutic target (Miyo et al. 2017; Nilsson et al. 2014; Pikman et al. 2016). For example, adding excess formate to cell cultures failed to rescue MTHFD2 silence cancer cells (Nilsson et al. 2014; Pikman et al. 2016), indicating that MTHFD2 expression may be required for cell growth. However, with following a shift to the cytosolic one-carbon pathway, lack of MTHFD2 did not affect cell survival (Ducker et al. 2016). SHMT2 enzyme knockdown did not observe the blockage of mitochondrial pathway and induce cell death, whereas glycine is deleted from culture medium, SHMT2-knockdown was found to impair cell growth (Jain et al. 2012; Kim et al. 2015).

Locasale et al. (2011) showed that decreasing expression of PGDH3 impaired proliferation in PGDH3 amplified cell lines by generating an inducible shRNA targeting PGDH3 which led to be blunt effects on the growth of breast cancer cells. Small molecule inhibitors of PGDH3 have been identified and were selectively toxic to cancer cell lines and successfully reduced cancer cell proliferation (Mullarky et al. 2016; Pacold et al. 2016). Studies demonstrated that high expression of SHMT2 and MTHFD2 in cancers was associated with lower recurrence-free survival and overall survival time (Koseki et al. 2018; Miyo et al. 2017). 


\subsection{Aims of the study}

Lung cancer is a major cause of cancer related deaths worldwide. With the development of molecular targeted therapy and immunotherapy, the landscape of lung cancer treatment has changed to combination therapy. However, systemic chemotherapy is still an indispensable treatment in lung cancer. Recent studies have demonstrated that one-carbon metabolism enzymes are upregulated in cancer cells. The aim of this study is to specify the role of onecarbon metabolism in lung cancer.

The first part of the project was to characterize the expression and prognostic impact of the one-carbon metabolism enzymes PGDH3, SHMT2, MTHFD2, MTHFD1 and TYMS by immunohistochemistry in human lung cancer samples. The second to evaluate one-carbon metabolism enzymes expression in human lung cancer cell lines.

It has been demonstrated in many tumors that one-carbon metabolism enzymes promote cancer cell proliferation. Hence, RNAi-mediated silencing of one-carbon metabolism enzymes was analyzed in lung cancer cells.

Finally, the changes in the cytotoxicity of cisplatin or pemetrexed agent in lung cancer cells after silencing of one-carbon metabolism enzymes were evaluated. 


\section{Material}

\subsection{Chemicals}

Table 1: List of chemicals

\begin{tabular}{|c|c|}
\hline Chemicals & Manufacturer \\
\hline Clearify Clearing Agent & $\begin{array}{l}\text { American MasterTech, Lodi, } \\
\text { California }\end{array}$ \\
\hline $\begin{array}{l}\text { EnVision Flex Target Retrieval } \\
\text { Solution, Ph Low (50X) }\end{array}$ & Dako, Hamburg, Germany \\
\hline $\begin{array}{l}\text { EnVision Flex Target Retrieval } \\
\text { Solution, } \mathrm{pH} \text { High (50X) }\end{array}$ & Dako, Hamburg, Germany \\
\hline Wash Buffer & Dako, Hamburg, Germany \\
\hline $\begin{array}{l}\text { EnVision Flex Peroxidase-Blocking } \\
\text { Reagent }\end{array}$ & Agilent, Santa Clara, California \\
\hline EnVision Flex Substrate Buffer & Agilent, Santa Clara, California \\
\hline EnVision Flex+ Mouse Linker SM804 & Agilent, Santa Clara, California \\
\hline EnVision Flex+ Rabbit Linker SM805 & Agilent, Santa Clara, California \\
\hline EnVision Flex/HRP & Agilent, Santa Clara, California \\
\hline $\begin{array}{l}\text { EnVision Flex Substrate Working } \\
\text { Solution DAB+ Chromogen }\end{array}$ & Agilent, Santa Clara, California \\
\hline Shandon Eosin $Y$ & $\begin{array}{l}\text { Thermo Scientific, Waltham, } \\
\text { Massachusettes }\end{array}$ \\
\hline Hematoxylin 7211 & $\begin{array}{l}\text { Thermo Scientific, Waltham, } \\
\text { Massachusettes }\end{array}$ \\
\hline Ethanol $99 \%$ & $\begin{array}{l}\text { Chemsolute, Th. Geyer GmbH \& } \\
\text { Co. KG, Renningen, Germany }\end{array}$ \\
\hline Xylol & $\begin{array}{l}\text { Chemsolute, Th. Geyer GmbH \& } \\
\text { Co. KG, Renningen, Germany }\end{array}$ \\
\hline Ethanol $96 \%$ & $\begin{array}{l}\text { Chemsolute, Th. Geyer GmbH \& Co. } \\
\text { KG, Renningen, Germany }\end{array}$ \\
\hline RPMI-1640 medium & Gibco, Waltham, USA \\
\hline
\end{tabular}




\begin{tabular}{ll} 
Chemicals & Manufacturer \\
\hline Fetal bovine serum (FBS) & Gibco, Waltham, USA \\
L-Glutamine & Gibco, Waltham, USA \\
Penicillin-Streptomycin & Gibco, Waltham, USA \\
$0.05 \%$ Trypsin-EDTA (1X) & Gibco, Waltham, USA \\
Muse ${ }^{\text {TM }}$ Count \& Viability Kit & Luminex, Austin, USA \\
4x Laemmli Samper Buffer & Bio-Rad Laboratories, Munich, \\
& Germany \\
10x Tris/Glycine/SDS & Bio-Rad Laboratories, Munich, \\
& Germany \\
Western Lightning Plus-ECL & PerkinElmer, Waltham,USA \\
CellTiter 96 Aqueous One Solution & Promega, Madison, Wisconsin, \\
Reagent & USA \\
Cisplatin & Hexal AG, Holzkirchen,Germany \\
HiPerFect Transfection Reagent & Qiagen, Hilden, Germany \\
Ponceau-S & Sigma-Aldrich, Munich, Germany \\
Protein marker & Thermo Scientific, Waltham, \\
& Massachusettes \\
\hline
\end{tabular}

\subsection{Primary antibodies}

Table 2: List of primary antibodies

\begin{tabular}{llccc} 
& & Western Blotting & \multicolumn{2}{c}{ Immunohistochemistry } \\
\cline { 3 - 5 } Antibodies & Company & concentration & concentration & pH \\
\hline PGDH3 & Sigma & $1: 1000$ & $1: 500$ & 6 (low) \\
SHMT2 & Cell signaling & $1: 1000$ & $1: 200$ & 6 (low) \\
MTHFD2 & Abnova & $1: 1000$ & $1: 100$ & 6 (low)
\end{tabular}


Western Blotting Immunohistochemistry

Antibodies Company concentration concentration pH

$\begin{array}{lllll}\text { MTHFD1 } & \text { ATLAS } & 1: 1000 & 1: 500 & 6 \text { (low) } \\ \text { TYMS } & \text { Abcam } & 1: 1000 & 1: 50 & 9 \text { (high) } \\ \text { PARK7 } & \text { Abcam } & 1: 1000 & & \end{array}$

\subsection{Small interfering RNA (siRNAs)}

Table 3: List of siRNAs

\begin{tabular}{ll}
\hline Targets & Company \\
\hline All-star control siRNA & Qiagen, Hilden, Germany \\
PGDH3 (SI00090405) & Qiagen, Hilden, Germany \\
SHMT2 (SI04176501) & Qiagen, Hilden, Germany \\
MTHFD2 (SI02664928) & Qiagen, Hilden, Germany \\
MTHFD1 (SI02653084) & Qiagen, Hilden, Germany \\
TYMS (SI02780757) & Qiagen, Hilden, Germany \\
\hline
\end{tabular}

\subsection{Equipment}

Table 4: List of equipment

\begin{tabular}{ll}
\hline Equipment & Manufacturer \\
\hline $10 \%$ SDS-PAGE Gel & Bio-Rad Laboratories GmbH, Munich, \\
& Germany \\
PVDF membrane & Bio-Rad Laboratories GmbH, Munich, \\
& Germany
\end{tabular}




\section{Equipment}

Heraeus flow hood

Standard-Incubator

$4^{\circ}$ Refrigerator

$-20^{\circ}$ Refrigerator

Systec VX-100, Autoclave

Systec VE-40, Autoclave

GFL 1004 Water Bath

Heraeus Microbiological

Incubator B12

IKA Vibrax-VXR Orbital Shaker

IKA Vibrax-RCT basic

Sanyo MDF-592 Laboratory

Freezer

Nalgene ${ }^{\circledR} \quad$ Cryo $\quad 1^{\circ} \mathrm{C} \quad$ Freezing

Container

Eppendorf Centrifuge 5424

Eppendorf Centrifuge 5430R

\section{Manufacturer}

Thermo, Fisher Scientific $\mathrm{GmbH}$, Schwerte, Germany

BINDER GmbH, Tuttlingen, Germany SIMENS Aktiengesellschaft, Munich, Germany

SIMENS Aktiengesellschaft, Munich, Germany

Thermo, Fisher Scientific $\mathrm{GmbH}$, Schwerte, Germany

Thermo, Fisher Scientific $\mathrm{GmbH}$, Schwerte, Germany

GFL Gesellschaft für Labortechnik $\mathrm{GmbH}$, Burgwedel, Germany

Thermo, Fisher Scientific $\mathrm{GmbH}$, Schwerte, Germany

KA-Werke GmbH \& Co. KG, Staufen, Germany

KA-Werke GmbH \& Co. KG, Staufen, Germany

SANYO Electric Co., Ltd., Osaka, Japan

Thermo, Fisher Scientific $\mathrm{GmbH}$, Schwerte, Germany

Eppendorf Vertrieb Deutschland $\mathrm{GmbH}$, Wesseling-Berzdorf, Germany Eppendorf Vertrieb Deutschland $\mathrm{GmbH}$, Wesseling-Berzdorf, Germany 


\section{Equipment}

Eppendorf Pipettes

Eppendorf Centrifuge 5804

Eppendorf ThermoMixer comfort

Trans-Blot ${ }^{\circledR} \quad$ Turbo $^{\mathrm{TM}} \quad$ Transfer

System

Polymax 1040 Shakers \& Mixers

Analytical Balance Sartorius

Research R200D

Zeiss Axiovert 25 mycrosocpy

Merck's Muse Cell Analyzer

Scotsman AF 80

Olympus BX41

Fusion Fx Vilber Lourmat

Pipette Tips

PCR tubes

Multi-tubes

Reaction tubes

Cryopure tubes

TC Flask T25/T75/T175

Pipette $5 \mathrm{ml} / 10 \mathrm{ml} / 25 \mathrm{ml}$

\section{Manufacturer}

Eppendorf Vertrieb Deutschland $\mathrm{GmbH}$, Wesseling-Berzdorf, Germany

Eppendorf Vertrieb Deutschland $\mathrm{GmbH}$, Wesseling-Berzdorf, Germany

Eppendorf Vertrieb Deutschland $\mathrm{GmbH}$, Wesseling-Berzdorf, Germany

Bio-Rad Laboratories $\mathrm{GmbH}$, Feldkirchen

Heidolph Instruments $\mathrm{GmbH} \&$ Co.KG, Schwabach, Germany

Sartorius AG, Göttingen, Germany

Carl Zeiss AG, Oberkochen, Germany

Merck KGaA, Darmstadt, Germany

SCOTSMAN, Milan, Italy

Olympus Europa SE \& Co. KG, Hamburg, Germany

Vilber Lourmat Deutschland $\mathrm{GmbH}$, Eberhardzell, Germany

SARSTEDT AG \& Co. KG, Nümbrecht, Germany 


\subsection{Human tissues}

Approval for using patient materials and all information in this study was obtained from the Ethics Committee of the University Medical Center Goettingen (\#1-2-08). All procedures were in accordance with the standards declaration of Helsinki and institutional, state, and federal guidelines. Specimens of tumor tissues were obtained from surgical resections at the Department of Thoracic Surgery of the University Medical Center Goettingen.

\subsection{Cell lines}

There were 16 human lung cancer cell lines in this study, which were purchased from American Type Culture Collection (ATCC):

(1) AC cell lines: H1993, H2228, H3122, HCC44, HCC78, HCC827.

(2) SQCLC cell line: HCC15, H2170, H520, EBC-1, EBC-1KRAS G12DWT.

(3) SCLC cell lines: DMS114, H1339, H69, H82, HCC33

\subsection{Software}

Table 5: List of software

\begin{tabular}{|c|c|}
\hline Software & Company \\
\hline Microsoft office & $\begin{array}{l}\text { Microsoft Corporation, Redmond, } \\
\text { USA }\end{array}$ \\
\hline ImageJ & $\begin{array}{l}\text { National Institute of Health, } \\
\text { Bethesda, USA }\end{array}$ \\
\hline GraphPad Prism 7 & $\begin{array}{l}\text { GraphPad Software, San Diego, } \\
\text { USA }\end{array}$ \\
\hline Magellan $^{\mathrm{TM}}$ & $\begin{array}{l}\text { Tecan Group Ltd., Männedorf, } \\
\text { Switzerland }\end{array}$ \\
\hline $\begin{array}{l}\text { i-control }{ }^{\mathrm{TM}} \quad \text { Microplate } \\
\text { Software }\end{array}$ & $\begin{array}{l}\text { Tecan Group Ltd., Männedorf, } \\
\text { Switzerland }\end{array}$ \\
\hline $\begin{array}{l}\text { ZEN } 2012 \text { (blue edition), version } \\
\text { 1.1.2.0 }\end{array}$ & $\begin{array}{l}\text { Carl Zeiss AG, Oberkochen, } \\
\text { Germany }\end{array}$ \\
\hline
\end{tabular}




\subsection{Laboratory made solutions}

Table 6: List of buffer and solution

\section{Buffer and solution}

Stock lysis buffer

$150 \mathrm{mM} \mathrm{NaCl}$

50 mM Tris/HCL pH 7.6

$5 \mathrm{mM} \mathrm{NaF}$

$1 \%$ NP40

Working lysis buffer

$10 \mu \mathrm{l}$ Sodium orthovanadate

$40 \mu$ l Complete-EDTA

$100 \mu \mathrm{l} 2 \%$ Lauryl

$850 \mu$ l Stock lysis buffer

10x Tris-buffered saline (TBS)

$4.2 \mathrm{~g}$ Tris

$26 \mathrm{~g}$ Tris-HCL

$292.4 \mathrm{~g} \mathrm{NaCl}$

$\mathrm{pH} 7.4$ with $\mathrm{HCl}$

$\mathrm{ddH}_{2} \mathrm{O}$ to $1 \mathrm{~L}$

1x Tris-buffered saline with Tween $2010 \mathrm{ml}$ Tween 20

(TBST)

$1 \mathrm{~L} 10 \mathrm{x}$ Tris-buffered saline

$9 \mathrm{LddH}_{2} \mathrm{O}$

Ponceau solution

$0.2 \mathrm{~g}$ Ponceau-Rot

$3 \mathrm{ml}$ Acetic acid

$\mathrm{ddH}_{2} \mathrm{O}$ to $100 \mathrm{ml}$ 


\section{Methods}

\subsection{Immunohistochemistry (IHC)}

The formalin-fixed and paraffin-embedded lung cancer tissues from 323 patients were combined into tissue microarrays (TMAs). Immunohistochemistry stainings were performed on a Dako Omnis advanced staining system and on the Dako Autostainer link 48 with the following steps: $2-\mu \mathrm{m}$ tissue sections were immersed in clearing agent for one cycle of one minute and subsequently incubated in EnVision Flex Target Retrieval Solution, pH low or high (see Material 2.2) for 30 $\min$. Next, slides were incubated with the primary antibodies at room temperature (RT) for 30 min and blocked in EnV FLEX Peroxidase-Blocking reagent for $3 \mathrm{~min}$. Then, slides were incubated with the secondary antibody EnVision FLEX/HRP for $20 \mathrm{~min}$ and DAB for $5 \mathrm{~min}$. Finally, samples were incubated in Hematoxylin for 3 min for counterstaining.

\subsection{IHC evaluation}

The TMAs stainings were analyzed by light microscopy at 100x and 400x. Staining intensity of PGDH3, SHMT2, MTHFD2, MTHFD1 and TYMS in the cytoplasm of cancer cells was classified as follows: 0 means negative expression; 1 means weak expression; 2 means strong expression.

\subsection{Cell culture}

Human lung cancer cells preserved in liquid nitrogen $-196^{\circ} \mathrm{C}$ were thawed in a water bath at $37^{\circ} \mathrm{C}$ for 2-3 min and then transferred to sterile centrifuge tubes with $9 \mathrm{ml}$ complete culture medium, next, centrifuged at 1,200 rounds per minute (RPM) at RT for 5 min. The supernatant was discarded. Subsequently, cells were transferred in $5 \mathrm{ml}$ culture medium to culture flasks. Cell lines were cultured in RPMI-1640 medium supplemented with $10 \%$ fetal bovine serum (FBS), $1 \%$ Penicillin/Streptomycin and $1 \%$ L-Glutamine in a humidified atmosphere of $5 \%$ $\mathrm{CO}_{2}$ at $37^{\circ} \mathrm{C}$. Generally, the medium was refreshed every $48-72 \mathrm{~h}$. When the cells 
were approximately $80 \%$ confluent, they were split at a $1: 2$ or $1: 5$ split ratio. All sub-cultures of cells were under 30 passages. Cultures were monitored using an inverted microscope to evaluate cell density and to confirm that there were no bacterial, fungal and mycoplasma. Adherent cell lines were harvested when cell confluency was close to $80 \%$. Old media was removed, cells were washed with 1x PBS twice then added about 2-3 $\mathrm{ml} 0.05 \%$ Trypsin-EDTA (1X) for $5 \mathrm{~min}$ to trypsinize cells. Cells were re-suspended and transferred into a sterile centrifuge tube with $10 \mathrm{ml}$ culture media. Then, after centrifuging at 1,200 RPM and RT for $5 \mathrm{~min}$, the supernatant was removed and the pellet was re-suspended by adding freezing medium. The vials were aliquoted to $1 \mathrm{ml}$ per vial, then placed in a freezing container and frozen overnight at $-80^{\circ} \mathrm{C}$. Vials were transferred to liquid nitrogen for indefinite storage.

\subsection{Cell counting}

Cells were harvested and re-suspended in cell culture medium as described in the cell culture to create single-cell suspensions, and then mixed cells with Muse $^{\mathrm{TM}}$ Count/Viability Reagent in a sample tube: $20 \mu \mathrm{l}$ of cell suspension into $380 \mu \mathrm{l}$ of Count/Viability Reagent. Samples were subjected to load and run assay by Muse ${ }^{\mathrm{TM}}$ Cell Analyzer with Count/Viability program.

\subsection{Protein isolation and western blot analysis}

1-5 $\times 10^{6}$ cells were washed twice with cold 1x PBS and collected in Eppendorf tubes. Afterwards, cells were lysed with lysis buffer on ice for $30 \mathrm{~min}$, then centrifuged at $14,000 \mathrm{RPM}, 4^{\circ} \mathrm{C}$ for $20 \mathrm{~min}$. The supernatant was transferred to a new Eppendorf tube. The DC ${ }^{\mathrm{TM}}$ protein assay kit was used to determine the concentration of protein. Solution $S$ was diluted 1:50 in solution A. $20 \mu \mathrm{l}$ of this mixture were added to a 96-well plate. $2 \mu \mathrm{l}$ protein lysate was added and $200 \mu \mathrm{l}$ solution B was added, then incubated for $10 \mathrm{~min}$ at RT. The absorbance was measured by Magellan ${ }^{\mathrm{TM}}$ software and the concentration was calculated according to an internal standard curve. The protein lysates were dissolved in $4 x$ Laemmli Samper buffer (dilute sample 3:1 with sample buffer) then denatured at 
$95^{\circ} \mathrm{C}$ for $5 \mathrm{~min}$. Then equivalent protein sample $(20 \mu \mathrm{g})$ was separated by $4-12$ $\%$ SDS-PAGE gel and electro-transferred onto polyvinylidene difluoride (PVDF) membrane by trans-blot turbo transfer system. The membrane was qualified with Ponceau-S and then blocked in $5 \%$ fat-free milk for $1 \mathrm{~h}$ at RT. Subsequently, the membrane was incubated overnight in primary antibody (Table 2) on the shaker at $4^{\circ} \mathrm{C}$. On the second day, the membrane was rinsed 3 times for $10-15$ min at RT with $1 \mathrm{x}$ TBST and incubated with secondary antibody for $1 \mathrm{~h}$ on the shaker at RT. Next, the membrane was rinsed 3 times for 10-15 min at RT with 1x TBST. Capturing signal was performed on a fusion imaging system. PARK7 was used as internal loading control (Wisniewski and Mann 2016). A summary of primary antibodies used is shown in materials (2.2).

\subsection{Cell viability assay}

2.500 cells were plated in 96 -well plates in $100 \mu \mathrm{l} /$ well culture medium. After $24 \mathrm{~h}$ of incubation the cells were treated with various concentration of cisplatin $(0 \mu \mathrm{M}, 1 \mu \mathrm{M}, 5 \mu \mathrm{M}, 10 \mu \mathrm{M}, 50 \mu \mathrm{M}, 100 \mu \mathrm{M}$ ) ) for $72 \mathrm{~h}$ or pemetrexed $(0 \mu \mathrm{M}$, $0.005 \mu \mathrm{M}, 0.025 \mu \mathrm{M}, 0.05 \mu \mathrm{M}, 0.25 \mu \mathrm{M}, 0.5 \mu \mathrm{M}, 2.5 \mu \mathrm{M}, 5 \mu \mathrm{M}, 25 \mu \mathrm{M}, 50 \mu \mathrm{M})$ for $96 \mathrm{~h}$. For measurements, the cells were incubated with $20 \mu \mathrm{l}$ of CellTiter 96 aqueous one solution reagent at $37^{\circ} \mathrm{C}, 5 \% \mathrm{CO}_{2}$ for $2 \mathrm{~h}$. The 96-well plates were measured by $\mathrm{i}$-control ${ }^{\mathrm{TM}}$ microplate reader software with the absorbance at $490 \mathrm{~nm}$ and the background absorbance at $650 \mathrm{~nm}$ subtracted. All experiments were repeated at least three times and each sample was plated in triplicate. The half maximal inhibitory concentration (IC50) was calculated using GraphPad Prim 7.0.

\subsection{SiRNAs transfection}

Unless stated otherwise, cells were transfected with $20 \mathrm{nM}$ siRNA using HiPerFect transfection reagent (Qiagen) according to the manufacturer's protocol. A summary of siRNAs used is shown in materials (2.3). 
For cell viability assays: $1-5 \times 10^{4}$ cells/well were seeded into the 96 -well plate with $175 \mu \mathrm{l}$ culture medium. siRNAs or control siRNA were incubated in HiPerFect transfection reagent and culture medium without serum for 5-10 min at RT to allow formation of transfection complexes. $25 \mu \mathrm{l}$ siRNA-HiPerFect reagent transfection complexes were added into a single well. After incubation for $24 \mathrm{~h}, 48 \mathrm{~h}, 72 \mathrm{~h}, 96 \mathrm{~h}, 120 \mathrm{~h}, 144 \mathrm{~h}$, the 96 -well plates were measured using CellTiter 96 aqueous one solution reagent.

For western blot analysis $100 \mu \mathrm{l}$ transfection medium containing $12 \mu \mathrm{l}$ HiPerFect, $9.6 \mu \mathrm{l} \mathrm{siRNA/negative} \mathrm{control}(20 \mathrm{nM})$ and $78.4 \mu \mathrm{l} \mathrm{RPMI}$ without serum was incubated at RT for $20 \mathrm{~min}$ and added to $1.5-6 \times 10^{5}$ cells in 6-well plate with $2.300 \mu \mathrm{l}$ culture medium just after seeding. Cells were collected for protein isolation and western blot analysis was performed after incubating for $72 \mathrm{~h}$ or $96 \mathrm{~h}$.

\subsection{Statistical analyses}

Statistical analysis was performed using GraphPad Prim 7 and ImageJ. Overall survival was analyzed using Kaplan-Meier analyses, differences in survival were calculated by log-rank test. All cell experiments were repeated at least three times and data were expressed as mean \pm standard error of mean (SEM). Statistical differences were tested by paired, two-tailed Student's $t$-test. The correlation between one-carbon metabolism enzymes and IC50 was assessed by Pearson's correlation test. Statistical differences were considered significant at $P<0.05$. 


\section{$4 \quad$ Results}

\subsection{Expression of one-carbon metabolism enzymes in human lung cancer samples.}

In order to detect the expression and role of one-carbon metabolism enzymes (highlighted in Figure 4) in human lung cancer, formalin-fixed and paraffinembedded lung cancer tissues from 323 patients were assembled into tissue microarrays. The collection included AC $(n=103), \operatorname{SQCLC}(n=183)$ and SCLC $(n=37)$. The number of male patients (AC: $n=59$ (57.3\%), SQCLC: $n=154$ (84.2\%), SCLC: $\mathrm{n}=27(73.0 \%)$ ) was higher than female patients (AC: $\mathrm{n}=44$ (42.7\%), SQCLC: $n=29$ (15.8\%), SCLC: $n=10(27.0 \%)$ ). The median age (AC group: 67 years (range 34-85), SQCLC group: 66 years (range 42-83), SCLC group: 67 years (range 50-81)) was similar among these three groups. More than half of patients with AC (65.1\%) and SQCLC (76.5\%) showed a moderately differentiated disease, while all SCLC were poorly differentiated by definition (100.0\%). The frequency of T1 stage in AC patients was $50.0 \%, 24.9 \%$ in SQCLC patients, and $75.7 \%$ in SCLC patients. The frequency of patients in with no lymph node metastasis (AC: $63.3 \%$, SQCLC: $55.6 \%$, SCLC: $75.0 \%$ ) was higher than the frequency of N1, N2 and N3 together. The median follow-up time was 23, 30 and 58 months for AC, SQCLC and SCLC, respectively and 201 deaths were reported. The clinical characteristics are shown in Table 7.

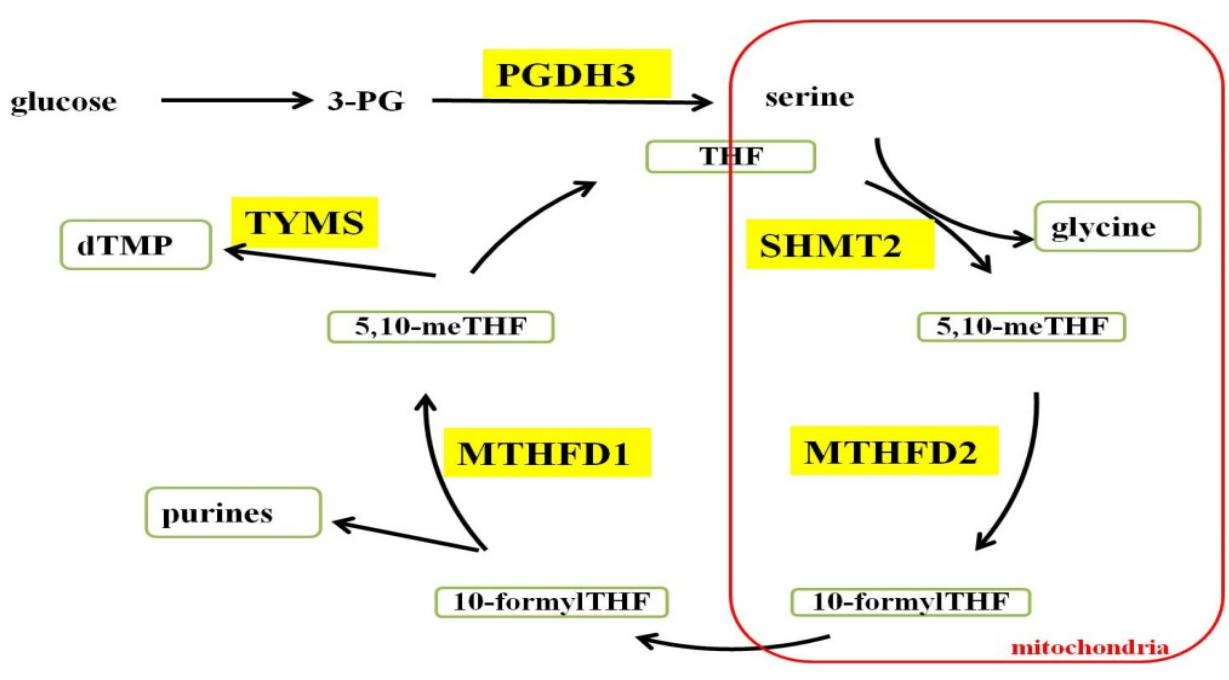

Figure 4: The one-carbon metabolism enzymes (highlighted) in cancer cells. 
Table 7: Clinical data summary

\begin{tabular}{|c|c|c|c|}
\hline Characteristic & $\begin{array}{c}A C \\
(n=103)\end{array}$ & $\begin{array}{l}\text { SQCLC } \\
(n=183)\end{array}$ & $\begin{array}{l}\text { SCLC } \\
(n=37)\end{array}$ \\
\hline \multicolumn{4}{|l|}{ Gender: } \\
\hline Male (\%) & $59(57.3)$ & $154(84.2)$ & $27(73.0)$ \\
\hline Female (\%) & $44(42.7)$ & $29(15.8)$ & $10(27.0)$ \\
\hline $\begin{array}{l}\text { Age median } \\
\text { (range, years) }\end{array}$ & $67(34-85)$ & $66(42-83)$ & $65(50-77)$ \\
\hline \multicolumn{4}{|l|}{ Tumor grade: } \\
\hline G $1(\%)$ & $9(8.7)$ & $0(0.0)$ & $0(0.0)$ \\
\hline G $2(\%)$ & $67(65.1)$ & $140(76.5)$ & $0(0.0)$ \\
\hline G $3(\%)$ & $27(26.2)$ & $43(23.5)$ & $37(100.0)$ \\
\hline \multicolumn{4}{|l|}{ Tumor stage: } \\
\hline T stage: & $n=102$ & $\mathrm{n}=181$ & $\mathrm{n}=37$ \\
\hline T $1(\%)$ & $51(50.0)$ & $45(24.9)$ & $28(75.7)$ \\
\hline T 2-4 (\%) & $51(50.0)$ & $136(75.1)$ & $9(24.3)$ \\
\hline N stage: & $\mathrm{n}=98$ & $\mathrm{n}=178$ & $n=28$ \\
\hline N $0(\%)$ & $62(63.3)$ & $99(55.6)$ & $21(75.0)$ \\
\hline N $1-3(\%)$ & $36(36.7)$ & $79(44.4)$ & $7(25.0)$ \\
\hline $\begin{array}{l}\text { Median follow-up } \\
\text { time (range, months) }\end{array}$ & $23(1-128)$ & $26(1-196)$ & $34(1-125)$ \\
\hline Reported deaths (\%) & $48(46.7)$ & $131(71.6)$ & $22(59.5)$ \\
\hline
\end{tabular}

\subsubsection{Expression of PGDH3 in human lung cancer samples.}

The described tissue samples of human lung cancers were immunohistochemically stained for PGDH3 and revealed a positive signal in the cytoplasma of the cancer cells. Signals were classified as either negative (Figure $5 \mathrm{~A}$ ), weak (Figure $5 \mathrm{~B}$ ) or strong staining (Figure $5 \mathrm{C}$ ) based on signal intensity. As shown in figure $5 \mathrm{D}$, the expression of $\mathrm{PGDH} 3$ varied considerably with a weak 
or strong expression in $64.7 \%$ of AC, $91.1 \%$ in SQCLC and $100.0 \%$ in SCLC. Patients with pulmonary adenocarcinomas showed significant differences $(P=$ 0.036 ) in overall survival between negative (median survival 44 months), weak (median survival 35 months) and strong staining (median survival 32 months), while there was no significant difference in both SQCLC $(P=0.292)$ and SCLC $(P=0.417)$ (Figure $5 \mathrm{E})$.
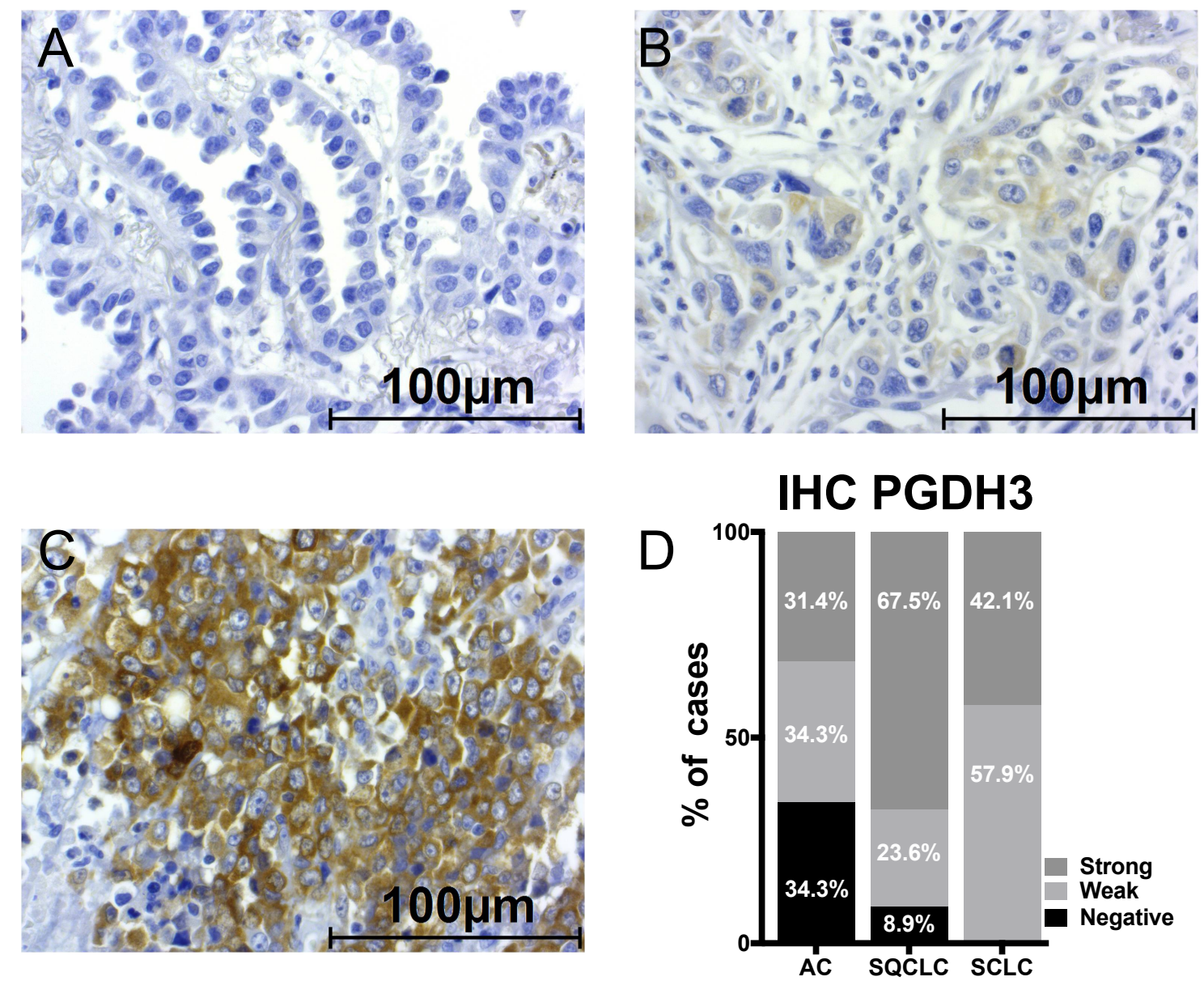
E

PGDH3 AC

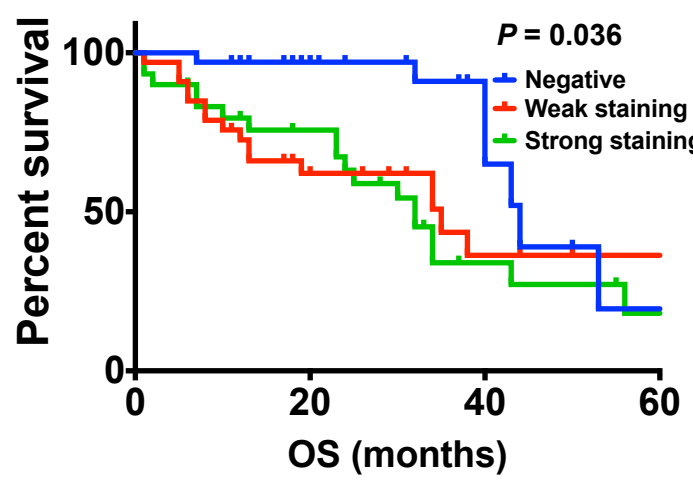

PGDH3 SCLC

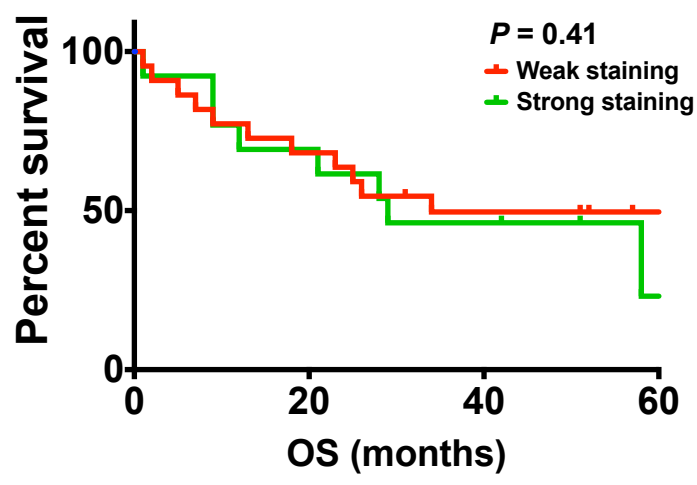

PGDH3 SQCLC

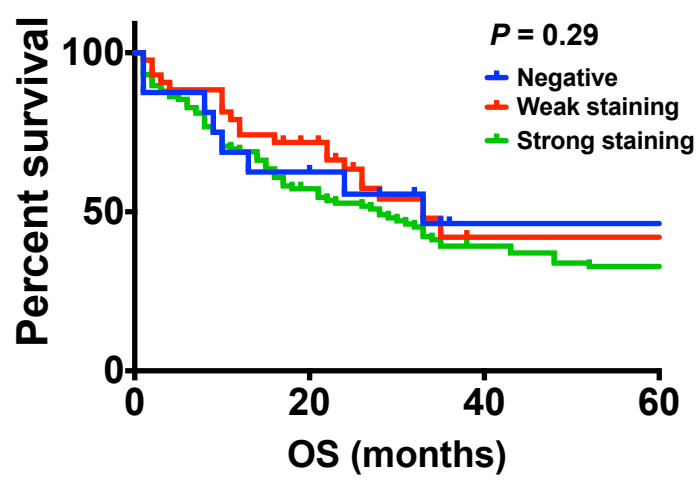

Figure 5: Prognostic significant of expression PGDH3 protein in lung cancer. A-D. Human lung cancer tissues were immunohistochemically stained to show the expression of $\mathrm{PGDH} 3$ protein: Negative expression of $\mathrm{PGDH} 3(\mathrm{~A})$. Positive $\mathrm{PGDH} 3$ protein signal in the cytoplasm of cancer cells including weak staining $(B)$ and strong staining $(C)$ on the basis of signal intensity. (D) The fraction of PGDH3 expression in human lung cancer tissues. (E) Survival analysis using Kaplan-Meier estimate and log-rank test grouped by IHC score (IHC: immunohistochemistry, AC: adenocarcinoma, SQCLC: Squamous cell lung carcinoma, SCLC: Small cell lung cancer).

\subsubsection{Expression of SHMT2 in human lung cancer samples.}

As previously described for PGDH3, the expression of SHMT2 was immunohistochemically examined and classified as negative (Figure $6 \mathrm{~A}$ ), weak (Figure $6 \mathrm{~B}$ ) or strong staining (Figure $6 \mathrm{C}$ ). The expression of SHMT2 in patients with AC (63.3\%), SQCLC (85.9\%), SCLC (92.1\%) is shown in figure 3-3 D. 
Kaplan-Meier analysis showed no significant differences in overall survival in patients with AC $(P=0.067)$, SQCLC $(P=0.42)$, SCLC $(P=0.73)$ (Figure $6 \mathrm{E})$.
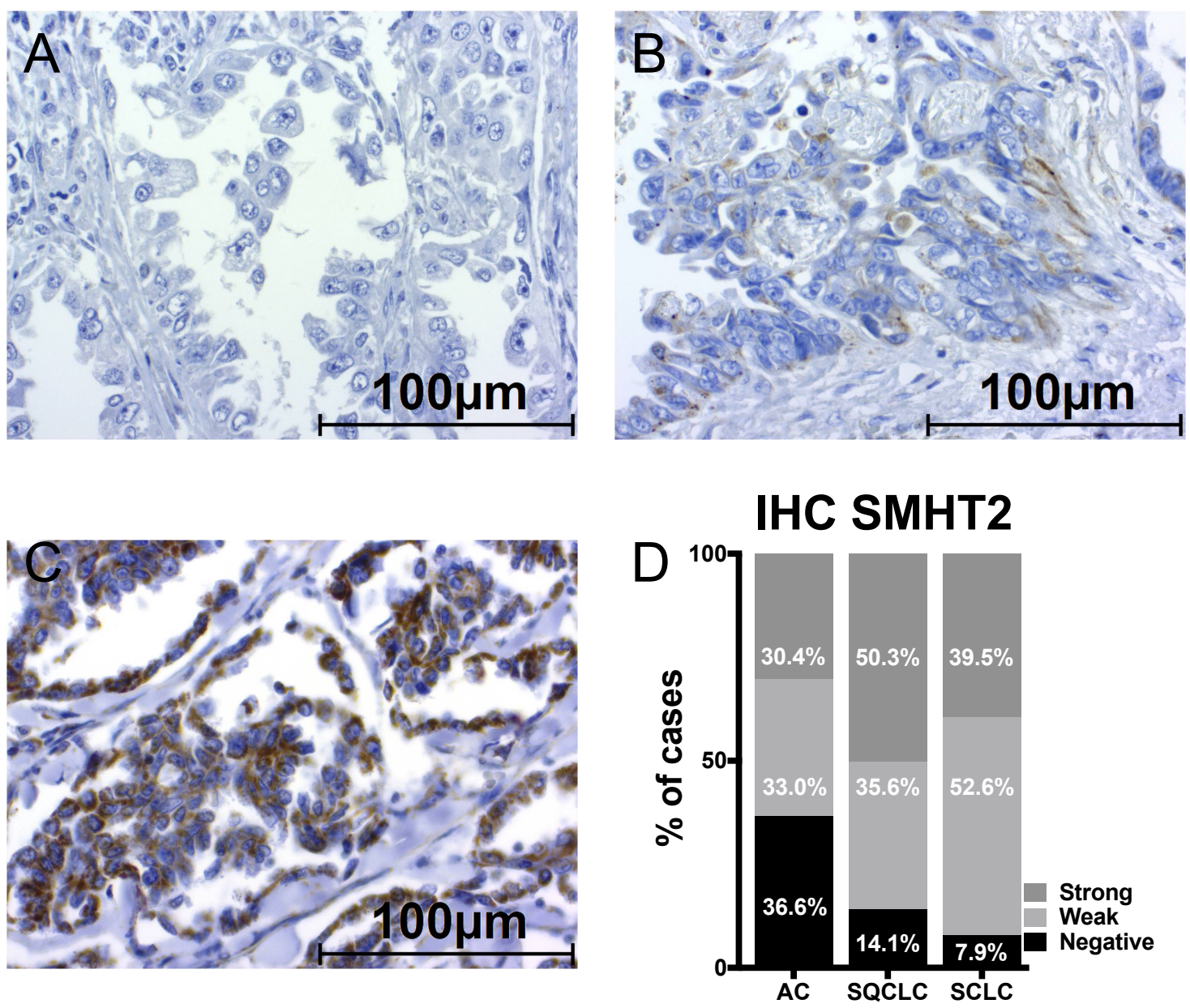
$E$

SHMT2 AC

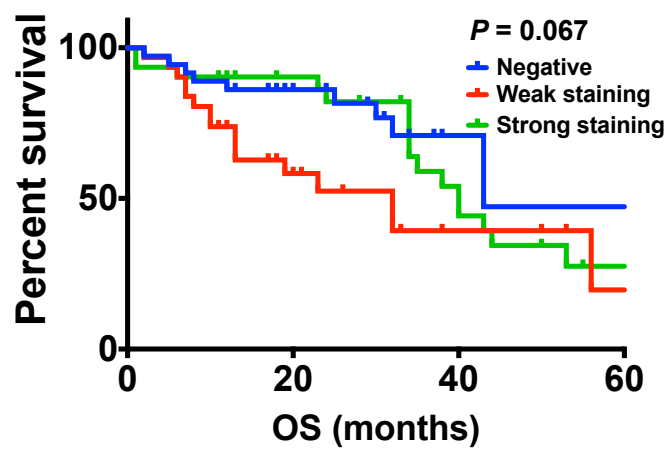

SHMT2 SCLC

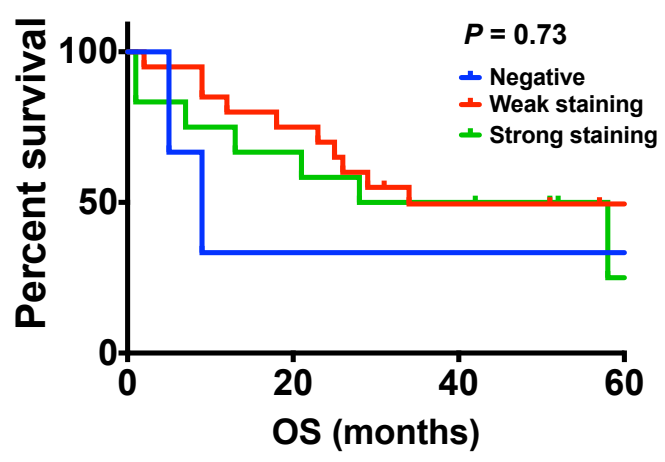

SHMT2 SQCLC

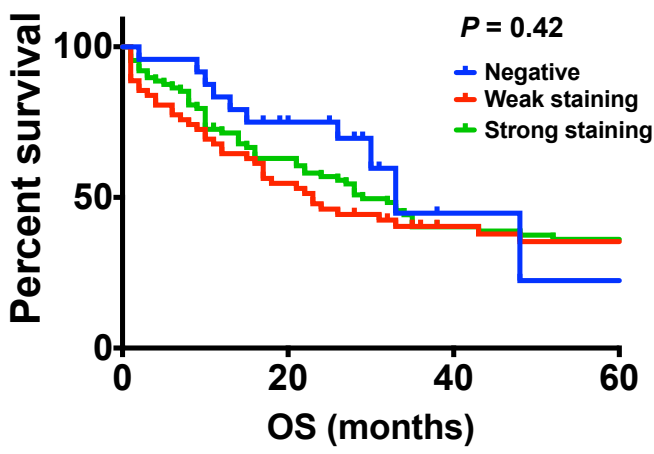

Figure 6: Expression of SHMT2 protein in lung cancer. A-D. Human lung cancer tissues were immunostained to show the expression of SHMT2 protein: Negative expression of SHMT2 (A). Positive SHMT2 protein signal in the cytoplasm of cancer cells including weak staining (B) and strong staining (C) on basis of signal intensity. (D) The fraction of SHMT2 expression in human lung cancer tissues. (E) Survival analysis using KaplanMeier estimate and log-rank test grouped by IHC score. 


\subsubsection{Expression of MTHFD2 in human lung cancer samples.}

The expression of MTHFD2 was examined as described before and staining was again classified as either negative (Figure $7 \mathrm{~A}$ ), weak (Figure $7 \mathrm{~B}$ ) or strong staining (Figure $7 \mathrm{C}$ ). MTHFD2 protein was strongly expressed in SQCLC (81.2 $\%)$, SCLC (81.6 \%), and AC (50.0\%) (Figure 7 D). Kaplan-Meier estimation of overall survival of patients among negative (median survival 43 months), weak staining (median survival 34 months) and strong staining (median survival 23 months) revealed a significant difference in AC $(P=0.044)$, but not in SQCLC and SCLC (Figure $7 \mathrm{E}$ ).



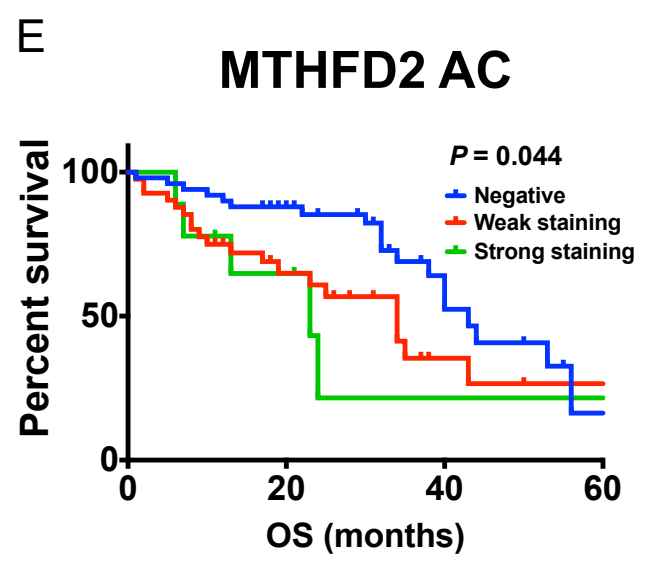

\section{MTHFD2 SQCLC}

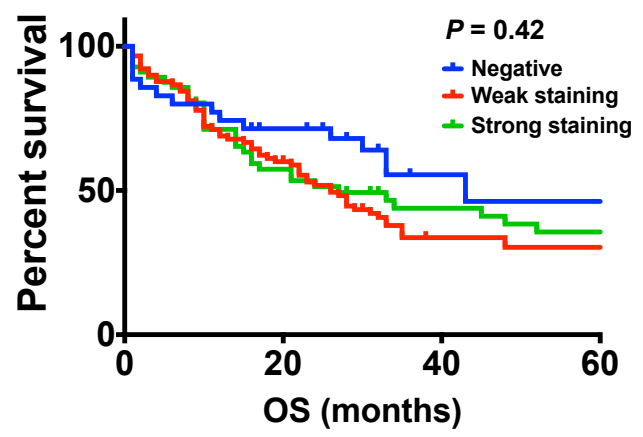

\section{MTHFD2 SCLC}

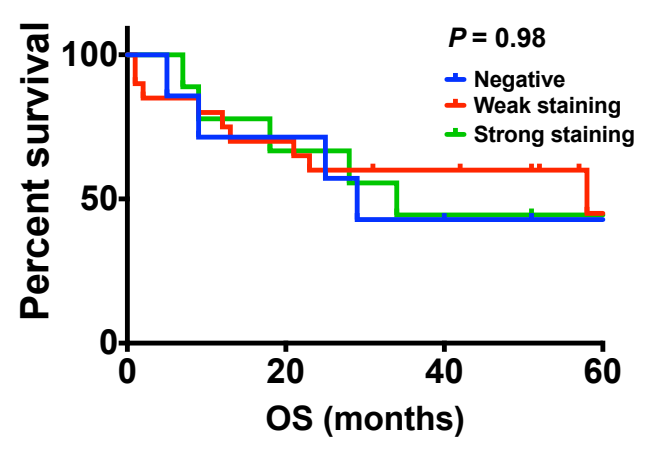

Figure 7: Prognostic significant of expression MTHFD2 protein in lung cancer. A-D. Human lung cancer tissues were immunostained to show the expression of MTHFD2 protein: Negative expression of MTHFD2 (A). Positive MTHFD2 protein signal is brown particles-like distribution in the cytoplasm of cancer cells including weak staining $(B)$ and strong staining (C) on basis of signal intensity. (D) The fraction of MTHFD2 expression in human lung cancer tissues. (E) Survival analysis using Kaplan-Meier estimate and log-rank test grouped by IHC score.

\subsubsection{Expression of MTHFD1 in human lung cancer samples.}

The same immunohistochemical analysis was performed for MTHFD1 (negative (Figure $8 \mathrm{~A}$ ), weak (Figure $8 \mathrm{~B}$ ) and strong staining (Figure $8 \mathrm{C}$ )). IHC results showed expression of MTHFD1 in patients among AC (94.0\%), SQCLC (84.8\%) and SCLC (82.4\%) (Figure 8 D). Kaplan-Meier analysis showed no significantly difference in overall survival of patients with $\mathrm{AC}(P=0.278)$, SQCLC $(P=0.984)$, or SCLC $(P=0.991)$ (Figure $8 \mathrm{E})$. 

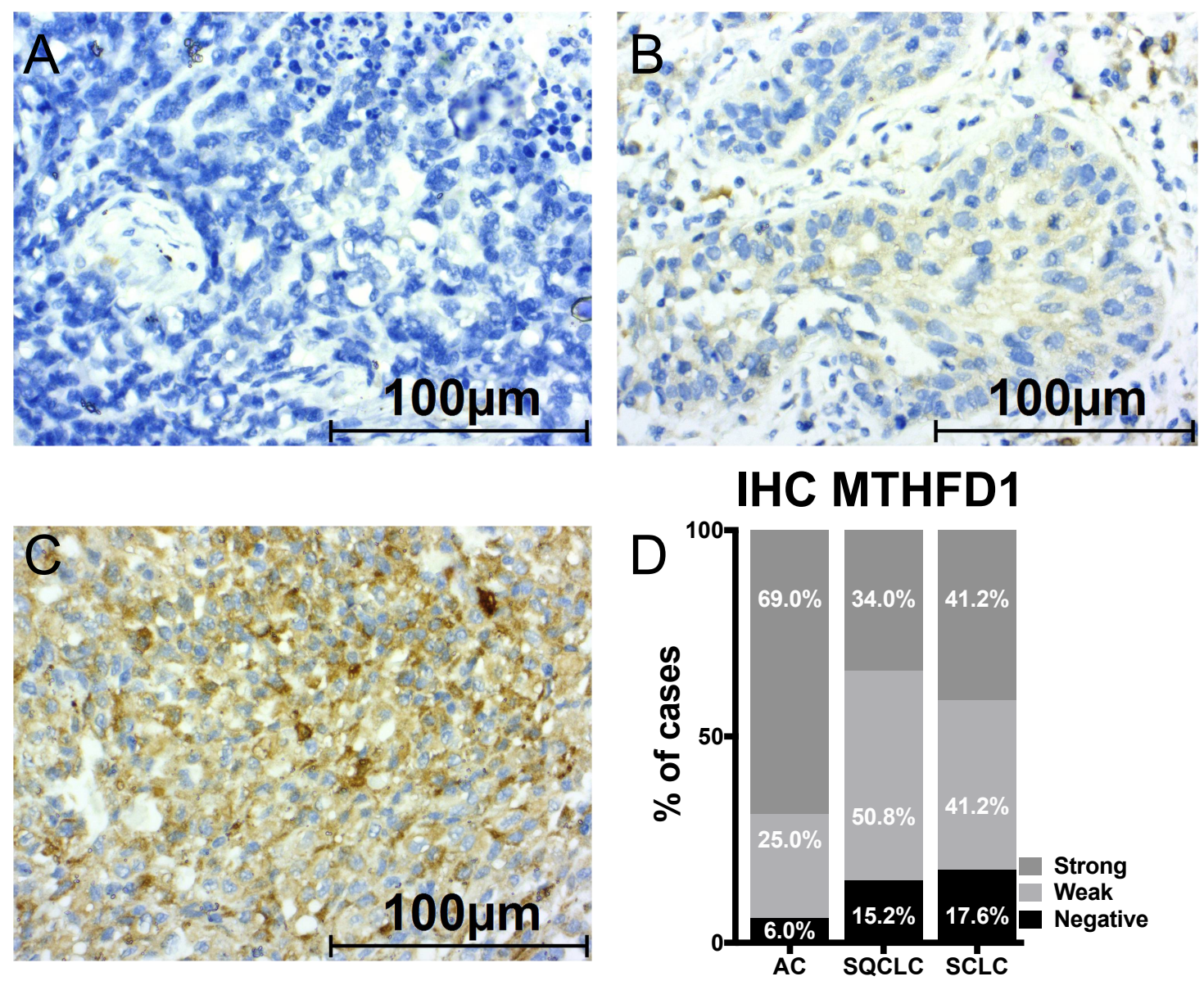


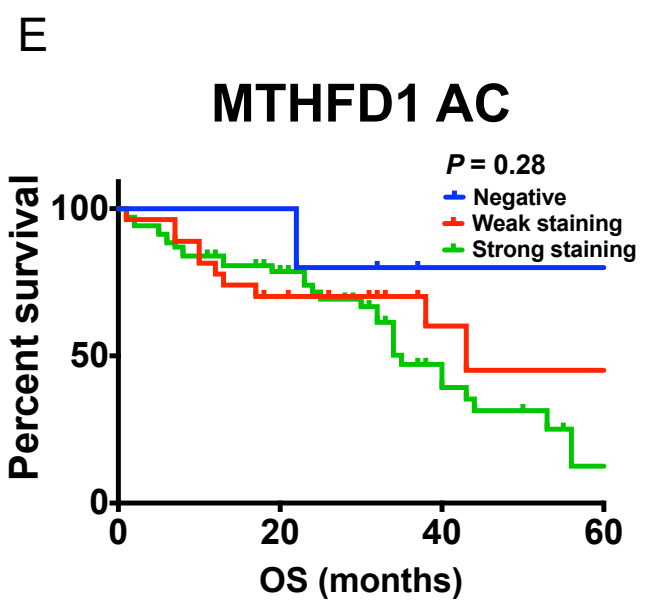

\section{MTHFD1 SQCLC}

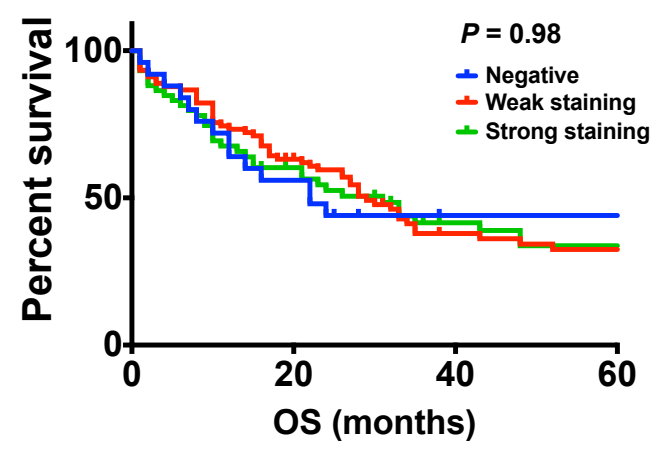

\section{MTHFD1 SCLC}

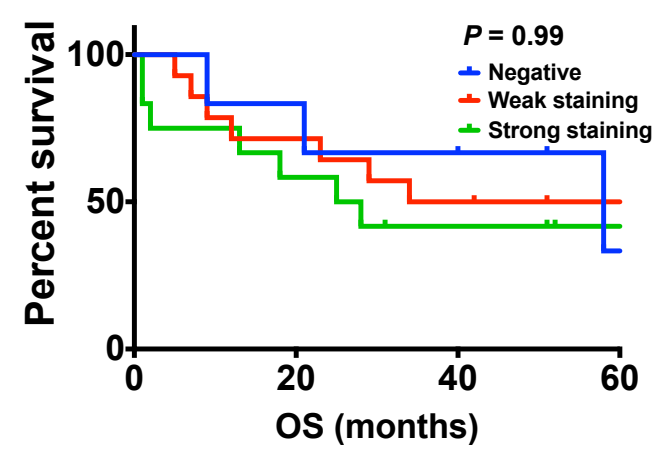

Figure 8: Expression of MTHFD1 protein in lung cancer. A-D. Human lung cancer tissues were immunostained to show the expression of MTHFD1 protein: Negative expression of MTHFD1 (A). Positive MTHFD1 protein in the cytoplasm of cancer cells including weak staining (B) and strong staining (C) on basis of signal intensity. (D). The fraction of MTHFD1 expression in human lung cancer tissues. (E). Survival analysis using KaplanMeier estimate and log-rank test grouped by IHC score. 


\subsubsection{Expression of TYMS in human lung cancer samples.}

On the basis of mentioned IHC criteria, TYMS was classified as either negative (Figure $9 \mathrm{~A}$ ), weak (Figure $9 \mathrm{~B}$ ) or strong staining (Figure $9 \mathrm{C}$ ). Expression of TYMS was seen in $86.2 \%$ of patients with AC, $80.0 \%$ in SQCLC, and $89.2 \%$ in SCLC (Figure $9 \mathrm{D}$ ). No significant differences in overall survival of patients with AC $(P=0.262)$, SQCLC $(P=0.349)$, and SCLC $(P=0.609)$ were obtained by Kaplan-Meier analysis (Figure $9 \mathrm{E}$ ).
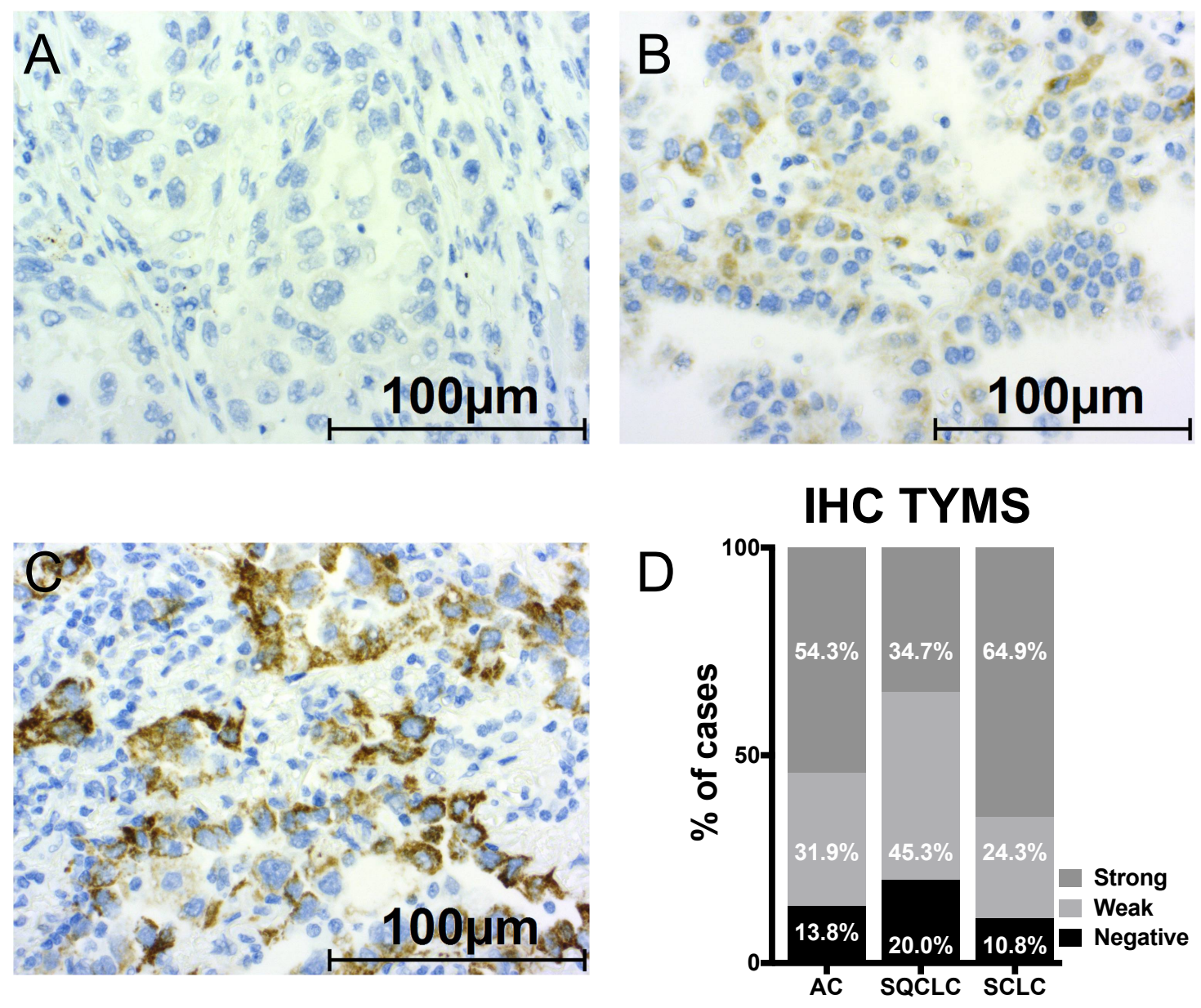
E

TYMS AC

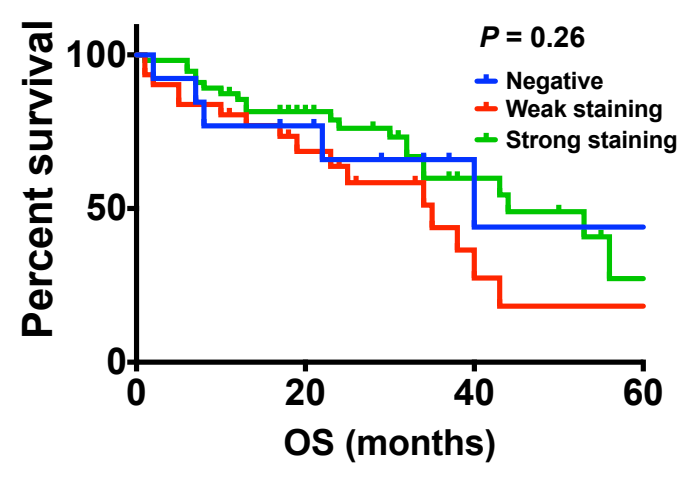

TYMS SCLC

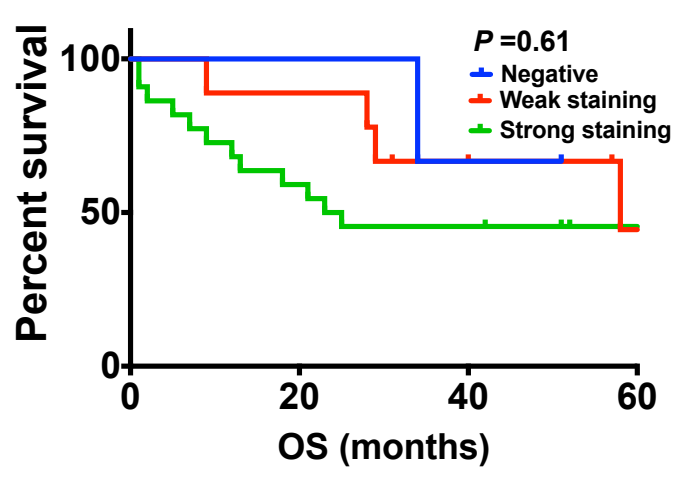

TYMS SQCLC

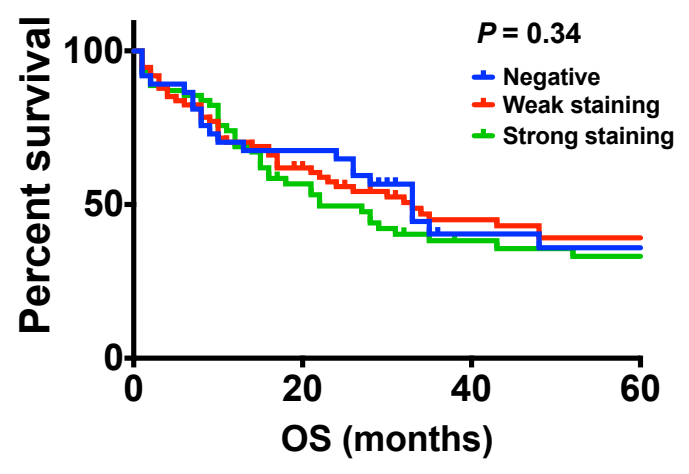

Figure 9: Expression of TYMS protein in lung cancer. A-D. Human lung cancer tissues were immunostained to show the expression of TYMS protein: Negative expression of TYMS (A). Positive TYMS protein signal in the cytoplasm of cancer cells including weak staining (B) and strong staining (C) on basis of signal intensity. (D) The fraction of TYMS expression in human lung cancer tissues. (E) Survival analysis using Kaplan-Meier estimate and log-rank test grouped by IHC score. 


\subsection{Expression of one-carbon metabolism enzymes in lung cancer cell lines.}

In order to investigate the function of one-carbon metabolism enzymes in human lung cancer, western blot analysis and cell viability assay were performed in vitro. Western blot analysis was used to examine the expression of one-carbon metabolism proteins in human lung cancer cell lines grouped by $A C(n=6)$, SQCLC $(n=5)$ and SCLC $(n=5)$ and to validate knockdown. To explore whether the one-carbon metabolism enzymes are associated with tumor cell proliferation, a cell viability assay was used to determine the cell viability by knockdown of onecarbon metabolism enzymes through siRNAs.

\subsubsection{PGDH3 enzyme in human lung cancer cell lines.}

As shown in figure $10 \mathrm{~A}$, western blots analysis showed a differential expression of PGDH3 in human lung cancer cell lines. Intensity of western blot bands were qualified using Image $\mathrm{J}$ and results presented in figure $10 \mathrm{~B}$. The cell line with the highest expression quantity of PGDH3 was eighteen times higher than the lowest one in AC cell lines, four times higher than the lowest one in SQCLC cell lines, seven times than the lowest one in SCLC cell lines. Then, cells were transfected with siRNAs targeting PGDH3 or control siRNA for $72 \mathrm{~h}$ and cell lysates were analyzed again by western immunoblotting to verify the decreased expression of PGDH3 compared to control siRNA (Figure $10 \mathrm{C}$ ).

Subsequently cell proliferation was assessed by cell viability assay and revealed that cell proliferation of all $A C$ cell lines was significantly reduced by $70.0 \%$ compared to controls at day 6 (Figure $11 \mathrm{~A}$ ). However, cell growth did not change when PGDH3 was knocked down with siRNA in SQCLC cell lines (Figure 11 B) and SCLC cell lines (Figure $11 \mathrm{C}$ ). Silencing $P G D H 3$ did thus not affect cell proliferation of SQCLC and SCLC cell lines. 


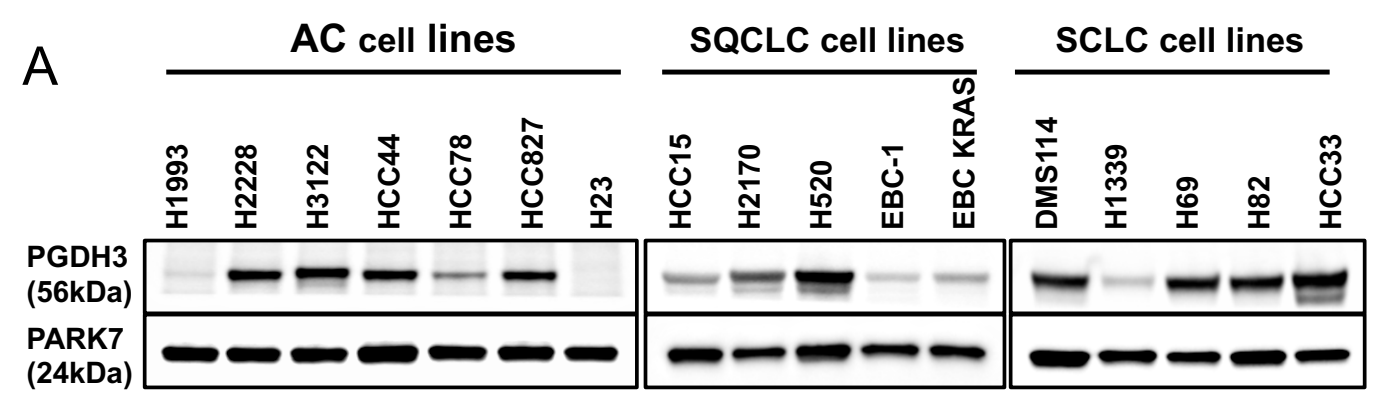

B

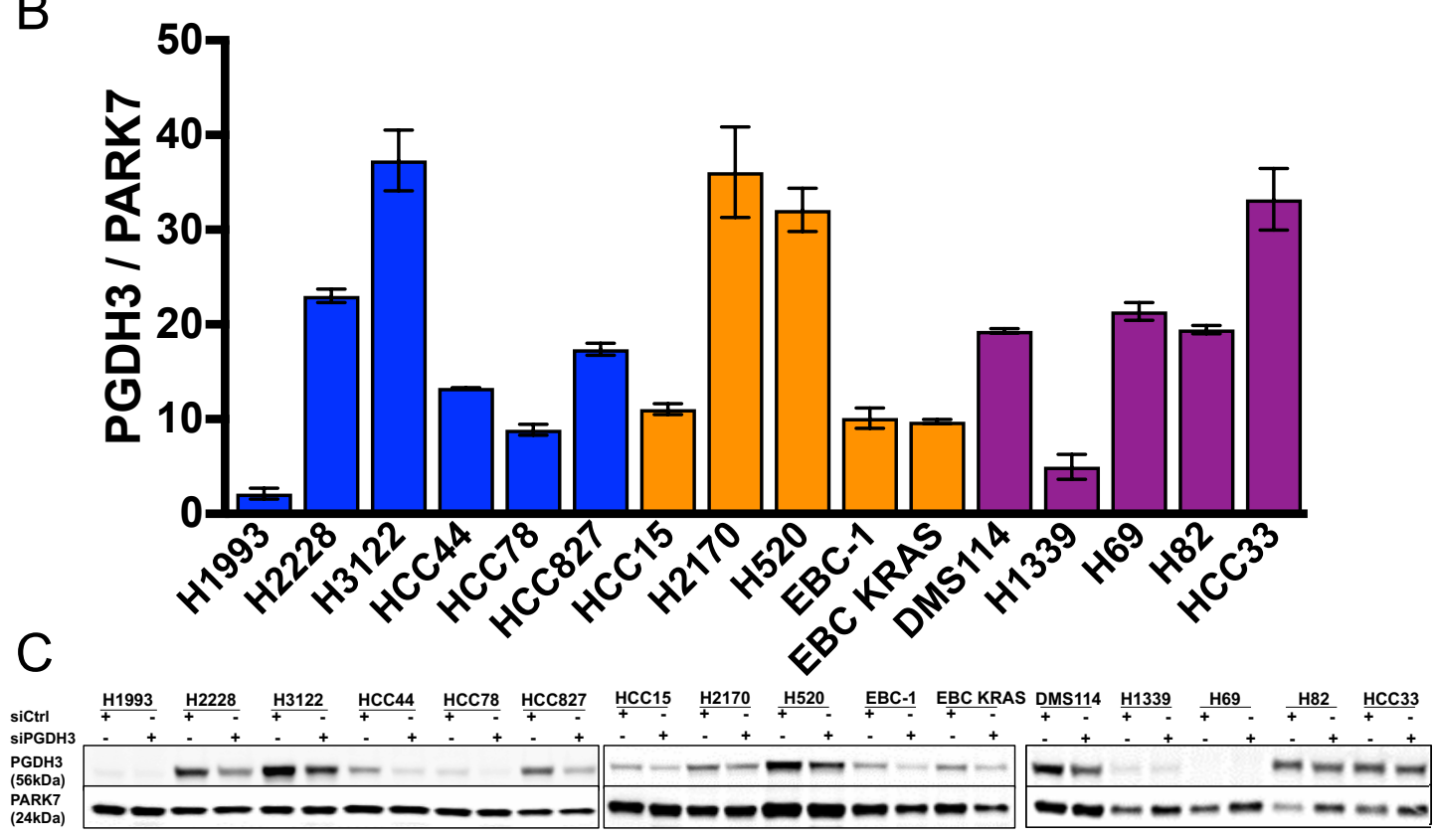

Figure 10: Expression of PGDH3 in human lung cancer cell lines. (A). Western blot analysis showing the expression of PGDH3 protein in AC, SQCLC and SCLC cell lines. PARK7 used as a loading control. Relative molecular mass in kDa shown on the left. The pictures are representative for three independent experiments. (B). Signal intensities of PGDH3 from AC, SQCLC and SCLC cell lines were normalized to PARK7 using ImageJ (the data are represented as mean \pm SEM of three independent experiments). (C). Western blot analysis showing the effect of control siRNA and PGDH3 siRNA on expression of $P G D H 3$ at protein lever in AC, SQCLC and SCLC cell lines after transfecting for $72 \mathrm{~h}$. 
A

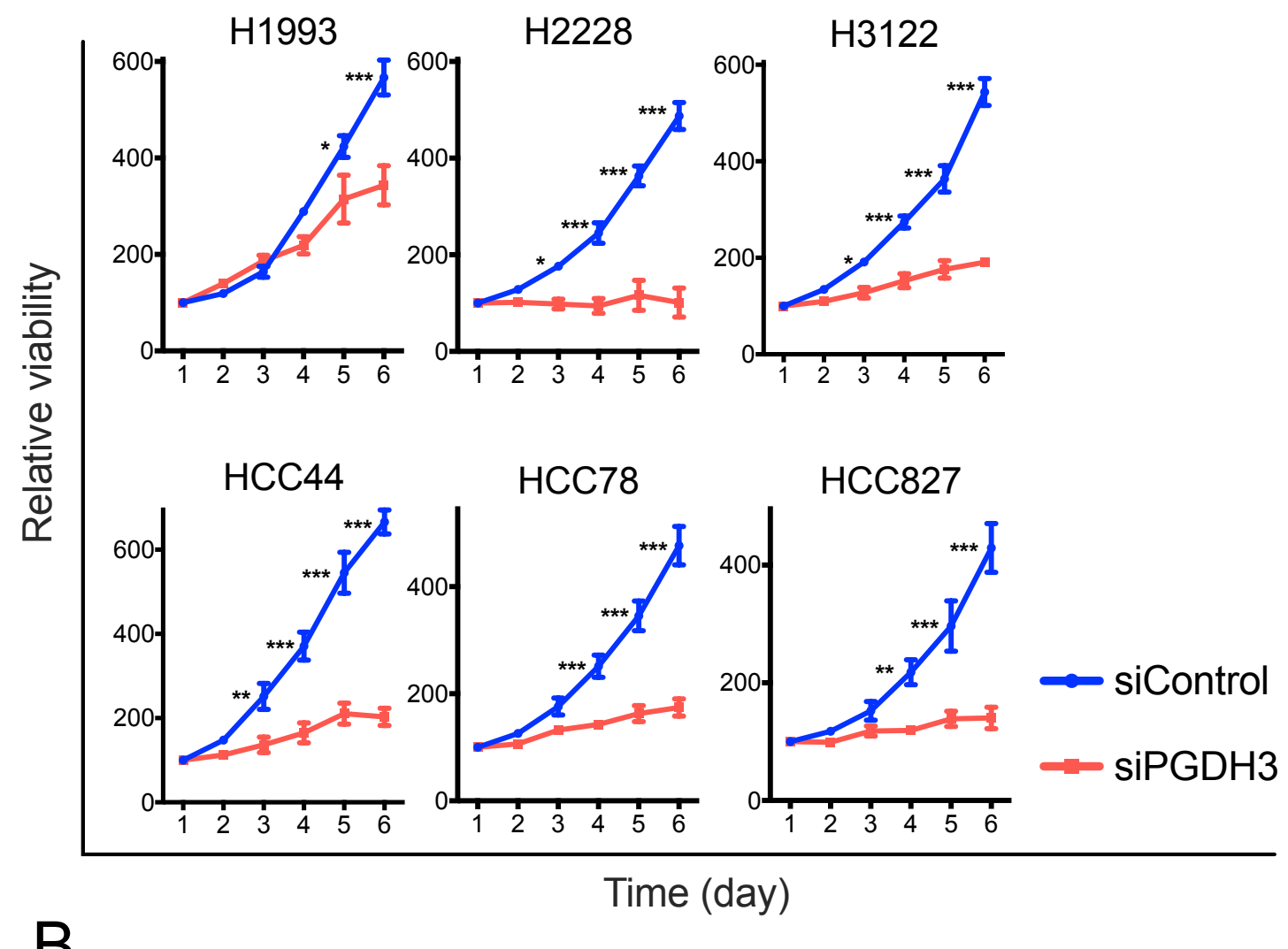

B

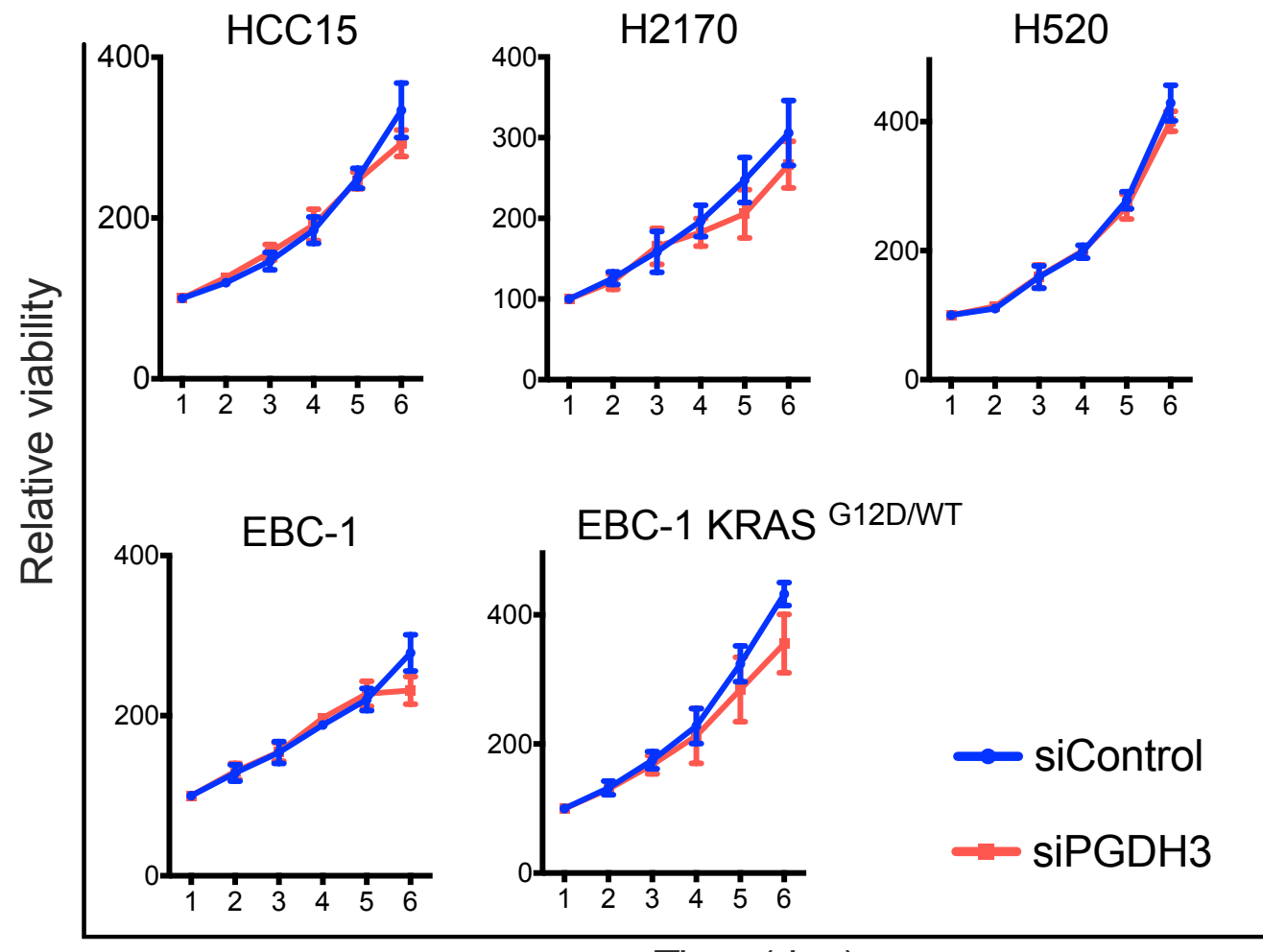

Time (day) 


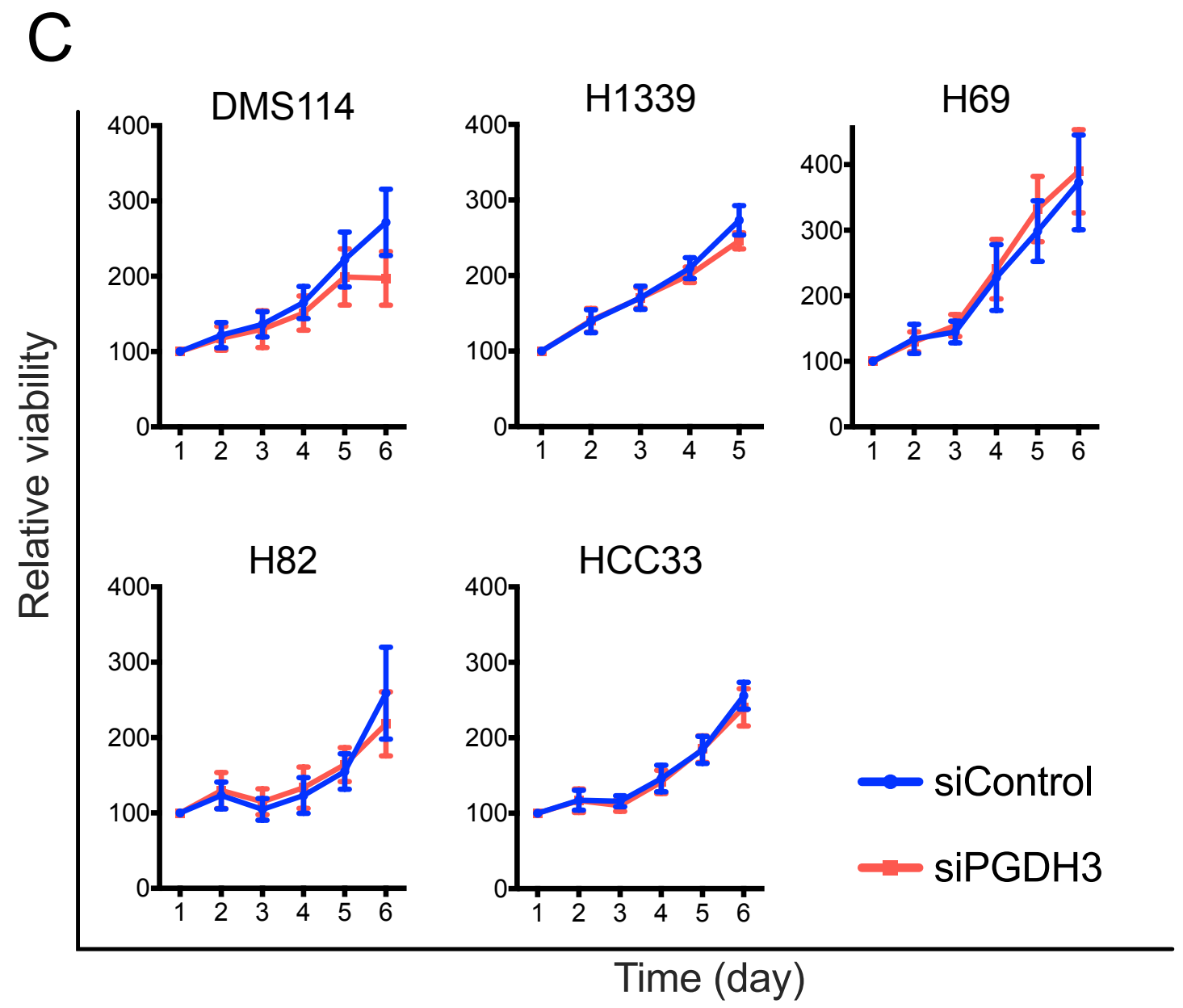

Figure 11: Knockdown of PGDH3 significant reduced cell proliferation of lung AC cell lines. Cell viability assays showing the cell proliferation of the AC (A), SQCLC (B), and SCLC cell lines $(C)$ after transfecting of siRNA against PGDH3 or control siRNA (the data are represented as mean $\pm S E M$ of at least three independent experiments with three technical replicates each, two-tailed Student's t-test: * $P<0.05$, ${ }^{* *} P<0.01,{ }^{* * *} P<$ $0.001)$.

\subsubsection{SHMT2 enzyme in human lung cancer cell lines.}

The expression of SHMT2 protein was examined by western blot analysis (Figure 12 A). Intensity of western blot bands was normalized to internal loading control PARK7 using ImageJ software. As shown in figure $12 \mathrm{~B}$, all of the examined cell lines expressed SHMT2 but to a various degree. Expression of SHMT2 in AC and SCLC cell lines was similar. The highest expression of SHMT2 was found in the SQCLC cell line H2170. 
Next, the described cell lines were transfected with siRNAs targeting SHMT2. Cells were incubated with SHMT2-siRNA or control siRNA for $72 \mathrm{~h}$ and then collected for cell lysis for western blot analysis. Results showed that SHMT2 protein levels were significantly inhibited by SHMT2 siRNA compared to control siRNA (Figure $12 \mathrm{C}$ ).

Further, cell proliferation was determined by cell viability assays. Cell proliferation was significantly reduced after transfecting SHMT2 siRNA for 4 days compared to control siRNA in AC cell lines (Figure $13 \mathrm{~A}$ ). Although cell proliferation of HCC15, one of SQCLC cell lines, was decreased after transfection with SHMT2 siRNA, the rest of SQCLC cell lines did not show consistent results (Figure $13 \mathrm{~B}$ ). Moreover, there was no impact of SHMT2 siRNA on cell proliferation of SCLC cell lines even after 6 days (Figure $13 \mathrm{C}$ ). 

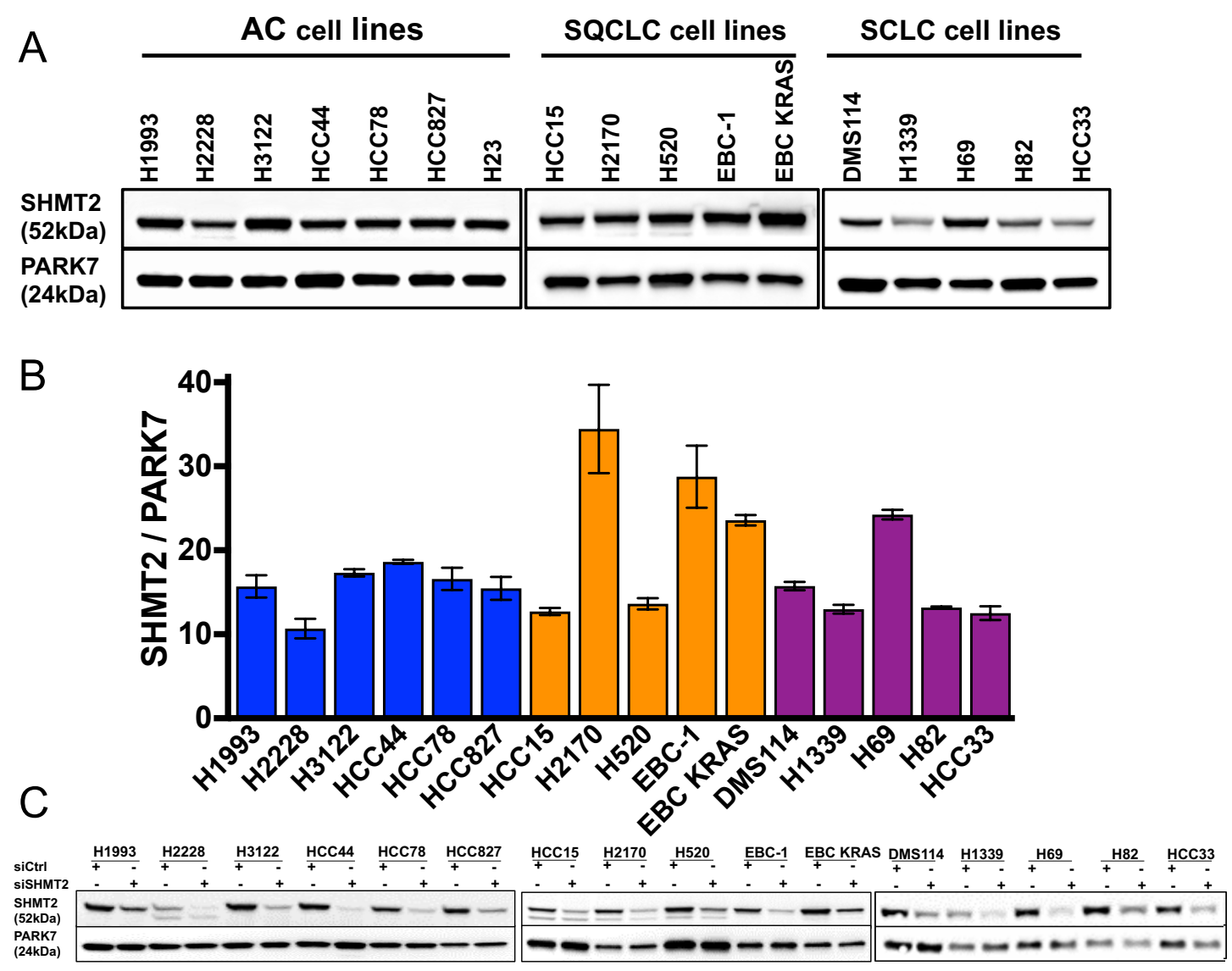

Figure 12: Expression of SHMT2 in human lung cancer cell lines. (A). Western blot analysis showing the expression of SHMT2 protein in AC, SQCLC and SCLC cell lines. PARK7 was used as loading control. Relative molecular mass in kDA is shown on the left. The pictures are representative of three independent experiments. (B). Signal intensities of SHMT2 from AC, SQCLC and SCLC cell lines were normalized to PARK7 using ImageJ (the data are represented as mean \pm SEM of three independent experiments). (C). Western blot analysis showing the effect of control siRNA and SHMT2 siRNA on SHMT2 protein level in AC, SQCLC and SCLC cell lines after $72 \mathrm{~h}$. 
A

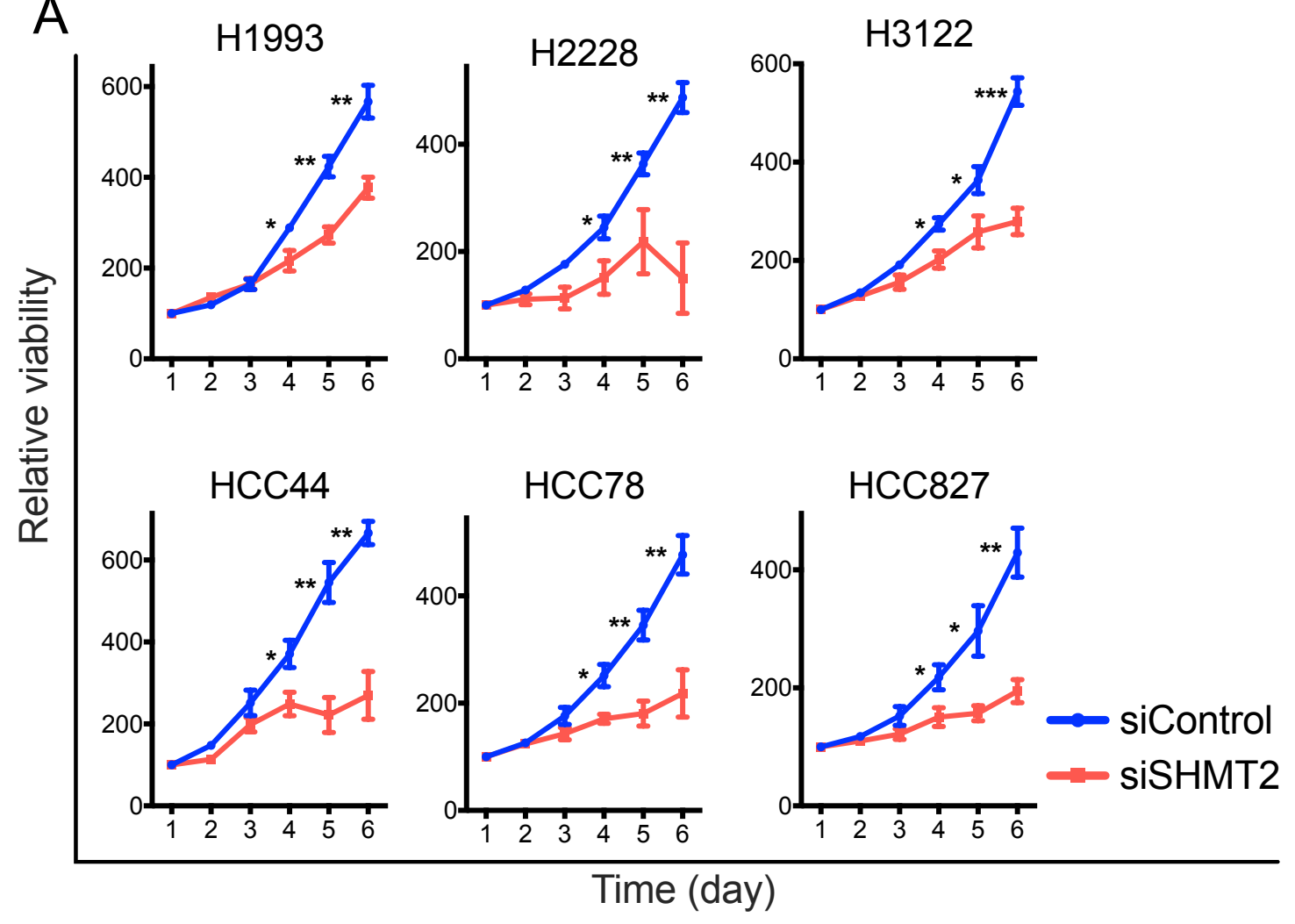

B

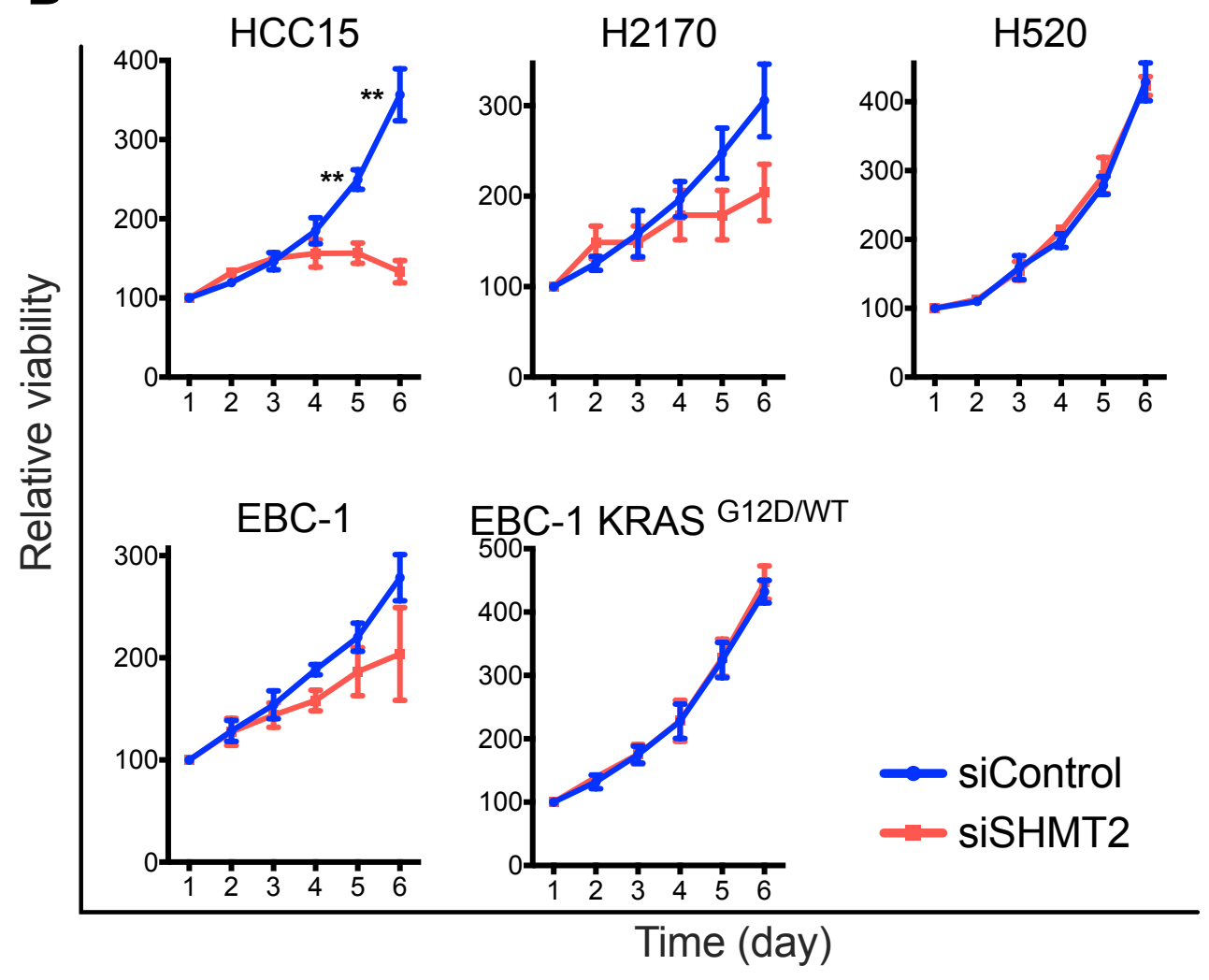




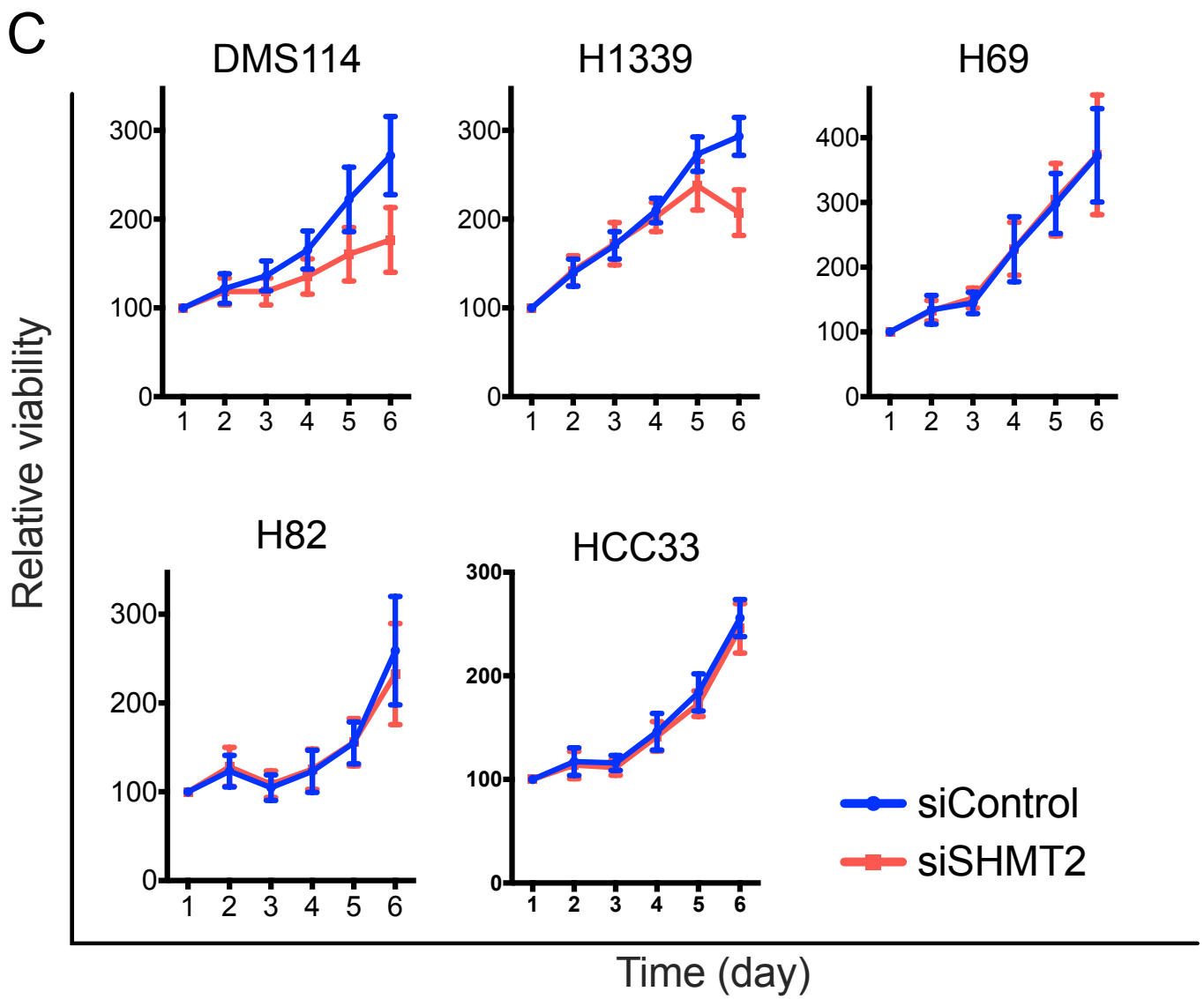

Figure 13: Knockdown of SHMT2 significant reduced cell proliferation of lung AC cell lines. Cell viability assays showing the cell proliferation of the $A C(A), S Q C L C(B)$ ,SCLC cell lines (C) after transfecting of siRNA against SHMT2 or control siRNA (the data are represented as mean \pm SEM of at least three independent experiments with three technical replicates each, two-tailed Student's t-test: ${ }^{*} P<0.05,{ }^{* *} P<0.01,{ }^{* * *} P<$ $0.001)$.

\subsubsection{MTHFD2 enzyme in human lung cancer cell lines.}

We detected MTHFD2 expression by western blot analysis (Figure $14 \mathrm{~A}$ ), which showed strong expression in AC, SQCLC and SCLC cell lines. To determine the expression quantity of MTHFD2 protein, western blot bands of MTHFD2 protein were normalized to internal loading control PARK7 and results were shown in figure $14 \mathrm{~B}$. All described cell lines expressed MTHFD2 protein. The AC cell line with the highest MTHFD2 protein level was HCC44. The SQCLC cell line with the highest MTHFD2 level was H2170. The lowest MTHFD2 protein level was found in the SCLC cell line H1339. Expression of MTHFD2 
protein in the remaining cell lines was in a similar range. Next, cells were transfected with siRNAs targeting MTHFD2 for $96 \mathrm{~h}$. Western blot analysis showed that MTHFD2 protein was significantly reduced compared to controls (Figure $14 \mathrm{C}$ ).

Subsequently, cell viability assay revealed that cell proliferation was significantly inhibited upon MTHFD2 knockdown starting from day 3 or day 4 and decreased by $50.0 \%$ after 6 days in all AC (Figure 15 A) and SQCLC cell lines (Figure $15 \mathrm{~B}$ ). However, cell proliferation was inhibited in only 3 of 5 SCLC cell lines by $50.0 \%$ after 6 days (Figure $15 \mathrm{C}$ ). 


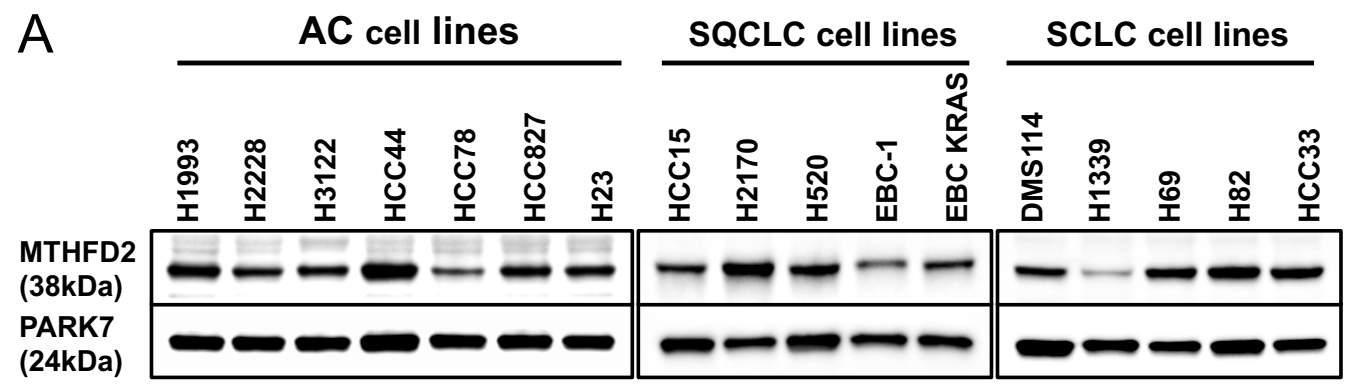

B

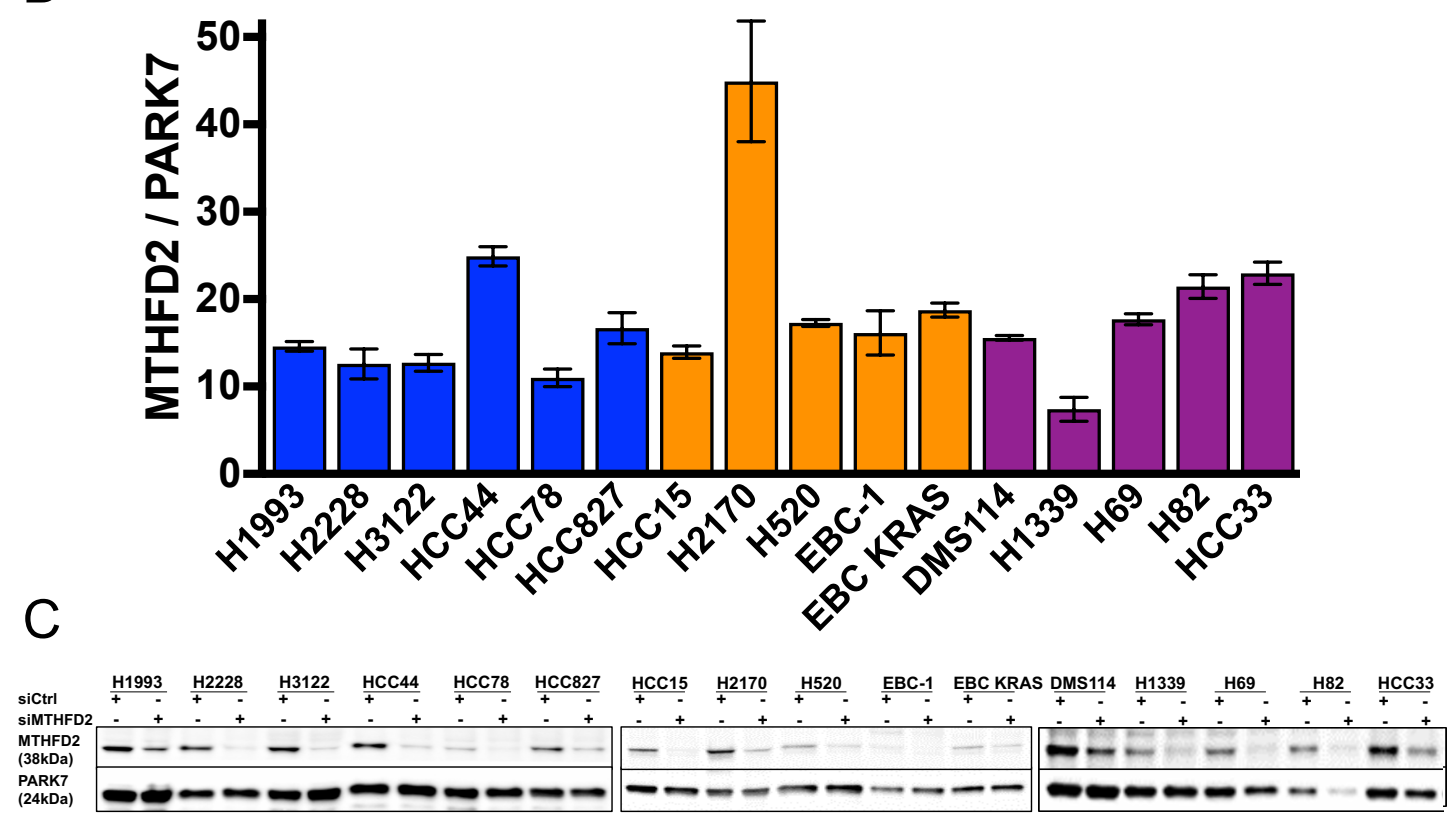

Figure 14: Expression of MTHFD2 in human lung cancer cell lines. (A). Western blot analysis showing the expression of MTHFD2 protein in AC, SQCLC and SCLC cell lines. PARK7 was used as loading control. Relative molecular mass in kDa is shown on the left. The pictures are representative for three independent experiments. (B). Signal intensities of MTHFD2 from AC, SQCLC and SCLC cell lines were normalized to PARK7 using ImageJ (the data are represented as mean $\pm S E M$ of three independent experiments). (C). Western blot analysis showing the effect of control siRNA and MTHFD2 siRNA on expression of MTHFD2 at protein lever in AC, SQCLC and SCLC cell lines after transfecting for $96 \mathrm{~h}$. 


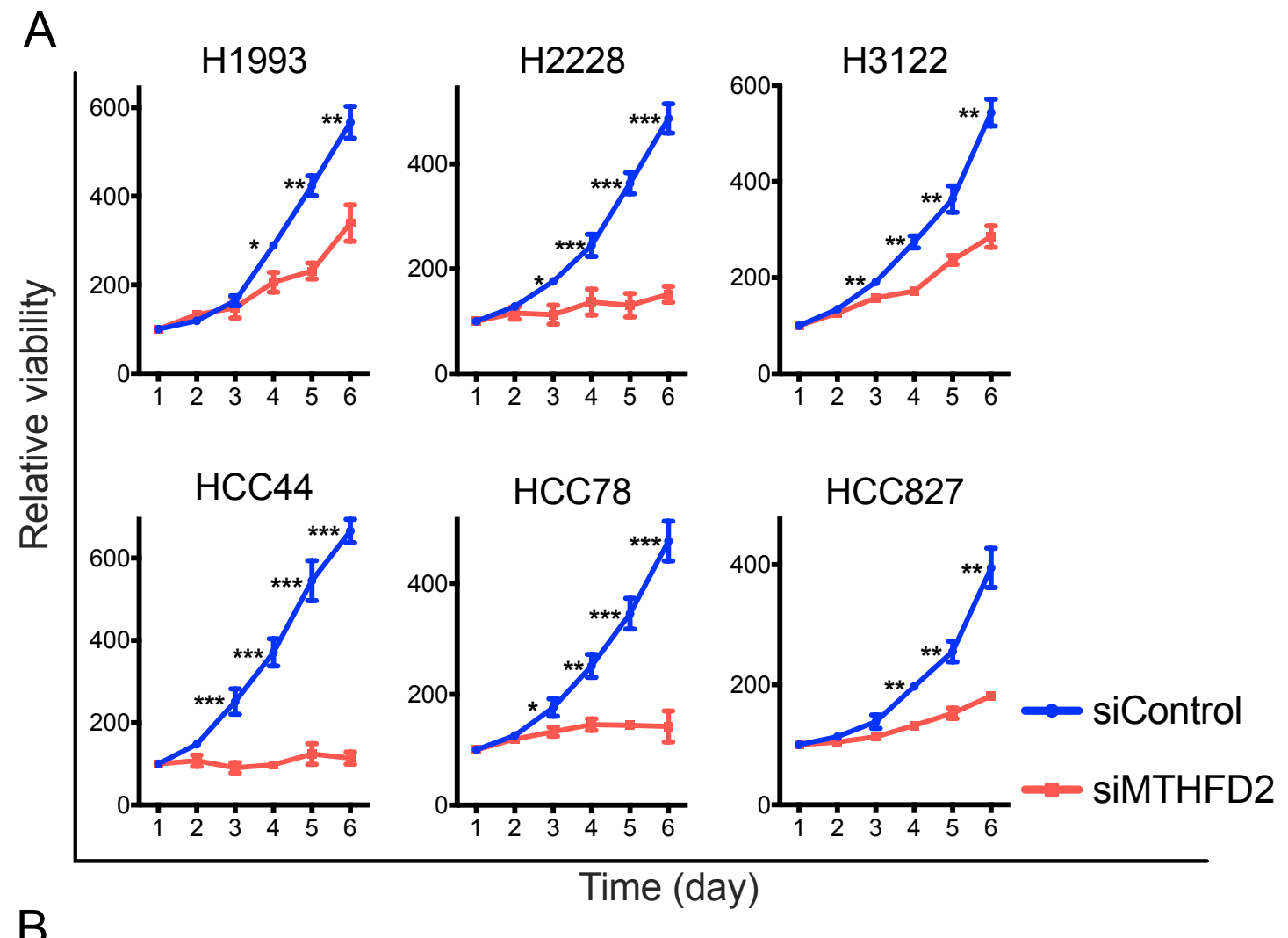

B

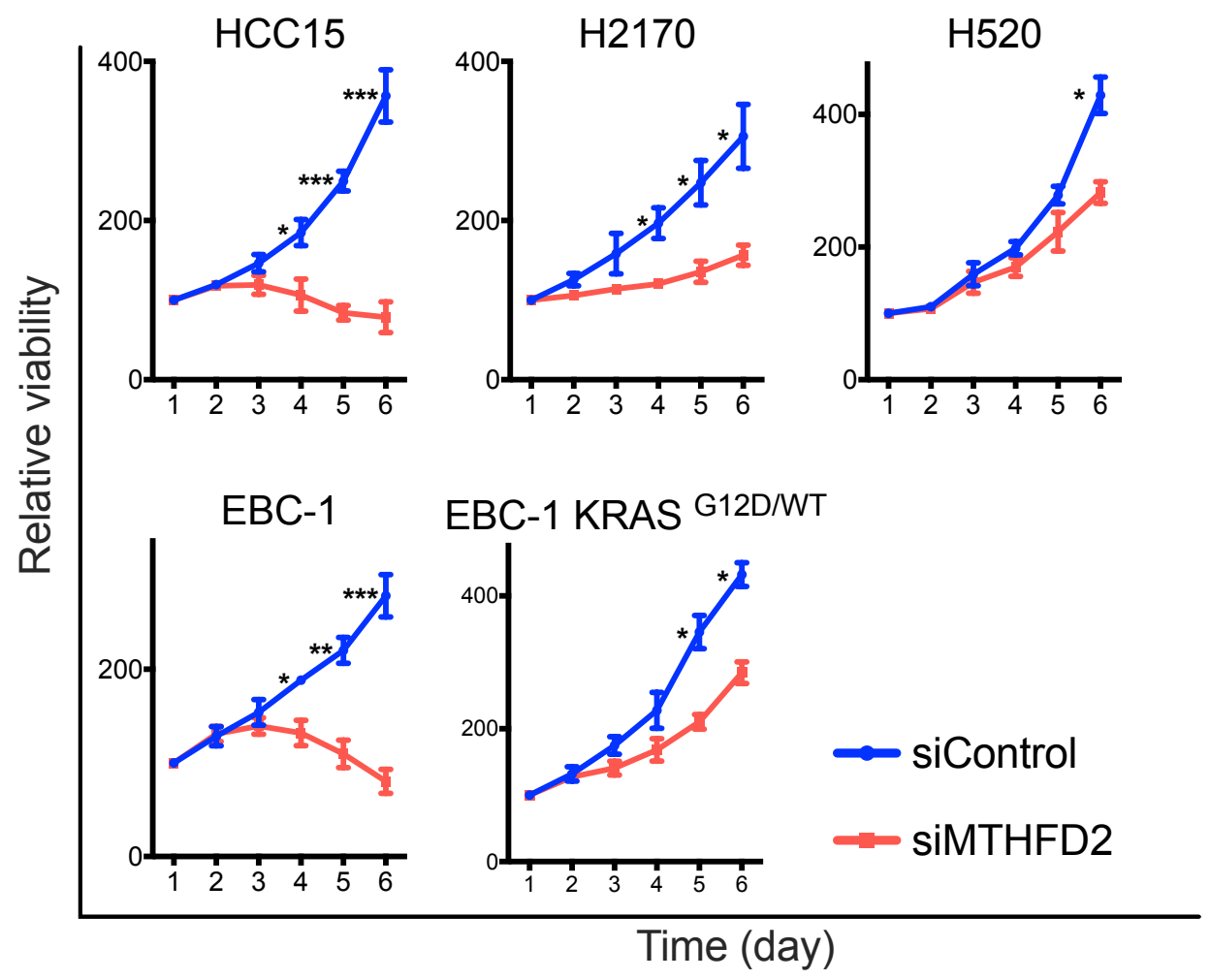




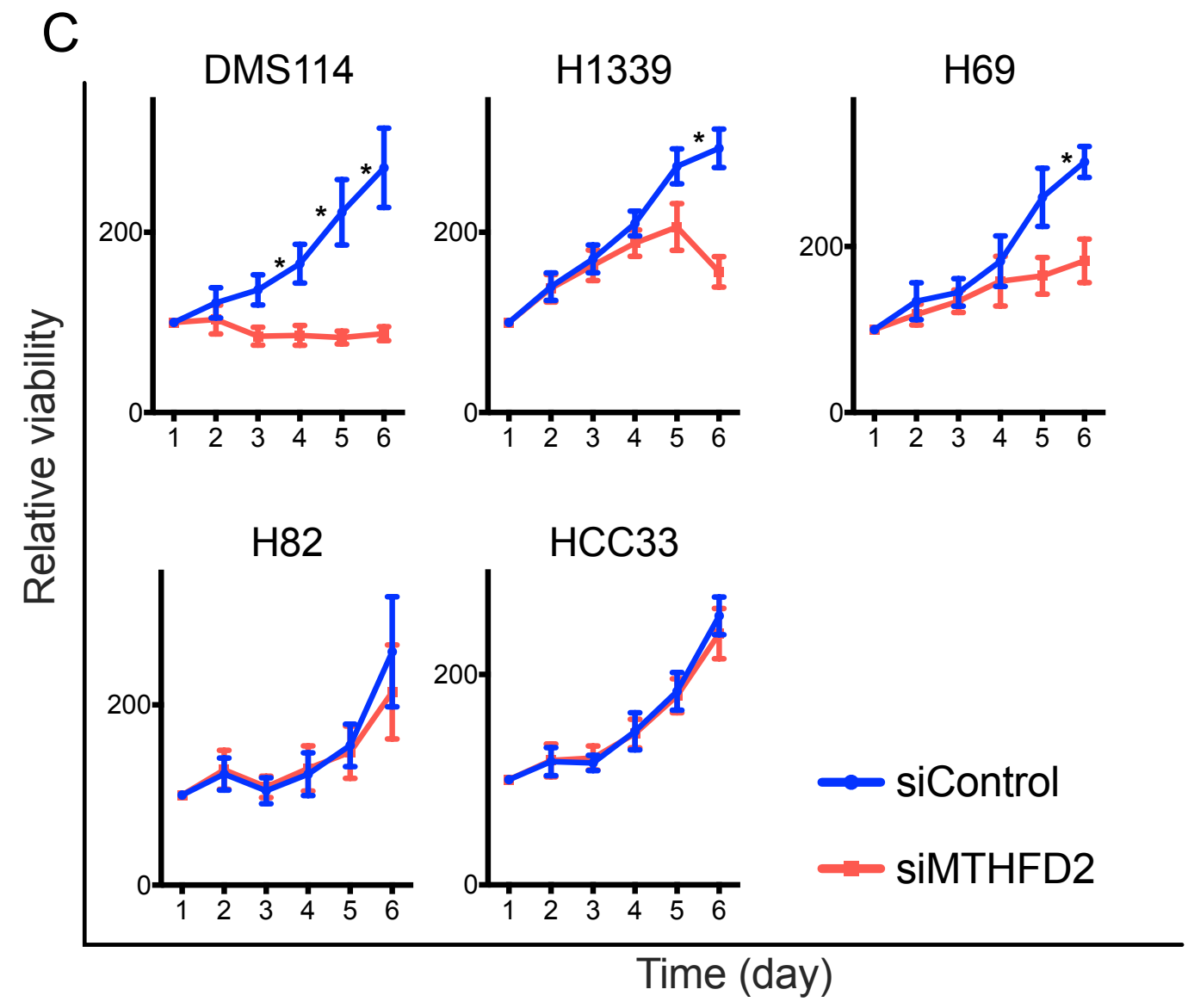

Figure 15: Knockdown of MTHFD2 significant reduced cell proliferation of lung cancer cell lines. Cell viability assays showing the cell proliferation of the $A C(A)$, SQCLC (B) ,SCLC cell lines (C) after transfecting of siRNA against MTHFD2 or control siRNA (the data are represented as mean \pm SEM of at least three independent experiments with three technical replicates each, two-tailed Student's t-test: * $P<0.05$, ${ }^{\text {** }}$ $\left.P<0.01,{ }^{* * *} P<0.001\right)$.

\subsubsection{MTHFD1 enzyme in human lung cancer cell lines.}

In figure $16 \mathrm{~A}$, western blot analysis revealed that MTHFD1 protein was abundantly expressed in AC, SQCLC and SCLC cell lines. Western blot bands displayed the highest expression of MTHFD1 protein in the SQCLC cell line H2170. The other SQCLC, AC, and SCLC cell lines showed similar MTHFD1 protein levels (Figure $16 \mathrm{~B}$ ). Next, cells were transfected with MTHFD1 siRNA or control siRNA for $96 \mathrm{~h}$. As shown in figure $16 \mathrm{C}$, MTHFD1 siRNA clearly inhibited the expression of MTHFD1 protein in both AC and SQCLC cell lines but not in all SCLC cell lines compared to control siRNA. 
Furthermore, cell viability assays were performed to detect cell proliferation after treatment with MTHFD1 siRNA or control siRNA. AC cell lines treated with MTHFD1 siRNA, showed dramatic growth arrest (Figure $17 \mathrm{~A}$ ). Particularly the proliferation of HCC44 cells was significantly inhibited from day 2. SQCLC cell lines showed similar changes and cell proliferation was significantly decreased after transfection with MTHFD1 siRNA (Figure 17 B). Among SQCLC cell lines, HCC15 was outstanding, since the proliferation was strongly decreased from day 2 after treatment with MTHFD1 siRNA. Consistent with western blot analysis results, not all SCLC cell lines showed response to MTHFD1 siRNA (Figure $17 \mathrm{C}$ ). Cell proliferation of DMS114, H1339 and H69 cell line was significantly reduced from day 4 or day 5 . 


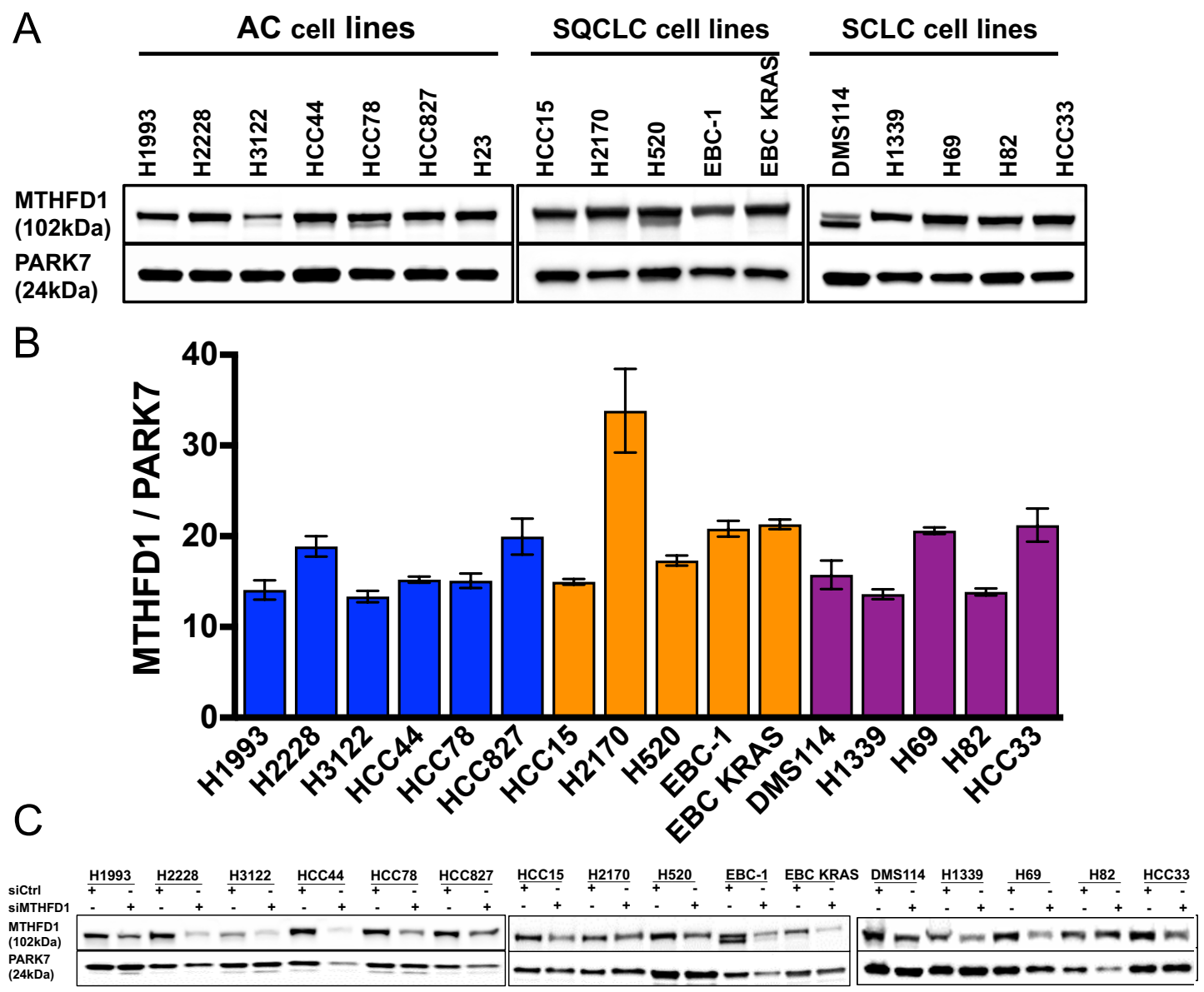

Figure 16: Expression of MTHFD1 in human lung cancer cell lines. (A). Western blot analysis showing the expression of MTHFD1 protein in AC, SQCLC and SCLC cell lines. PARK7 used as loading control. Relative molecular mass in kDa is shown on the left. The pictures are representative of three independent experiments. (B). Signal intensities of MTHFD1 from AC, SQCLC and SCLC cell lines were normalized to PARK7 using ImageJ (the data are represented as mean \pm SEM of three independent experiments). (C). Western blot analysis showing the effect of control siRNA and MTHFD1 siRNA on expression of MTHFD1 at protein lever in AC, SQCLC and SCLC cell lines after transfecting for $96 \mathrm{~h}$. 


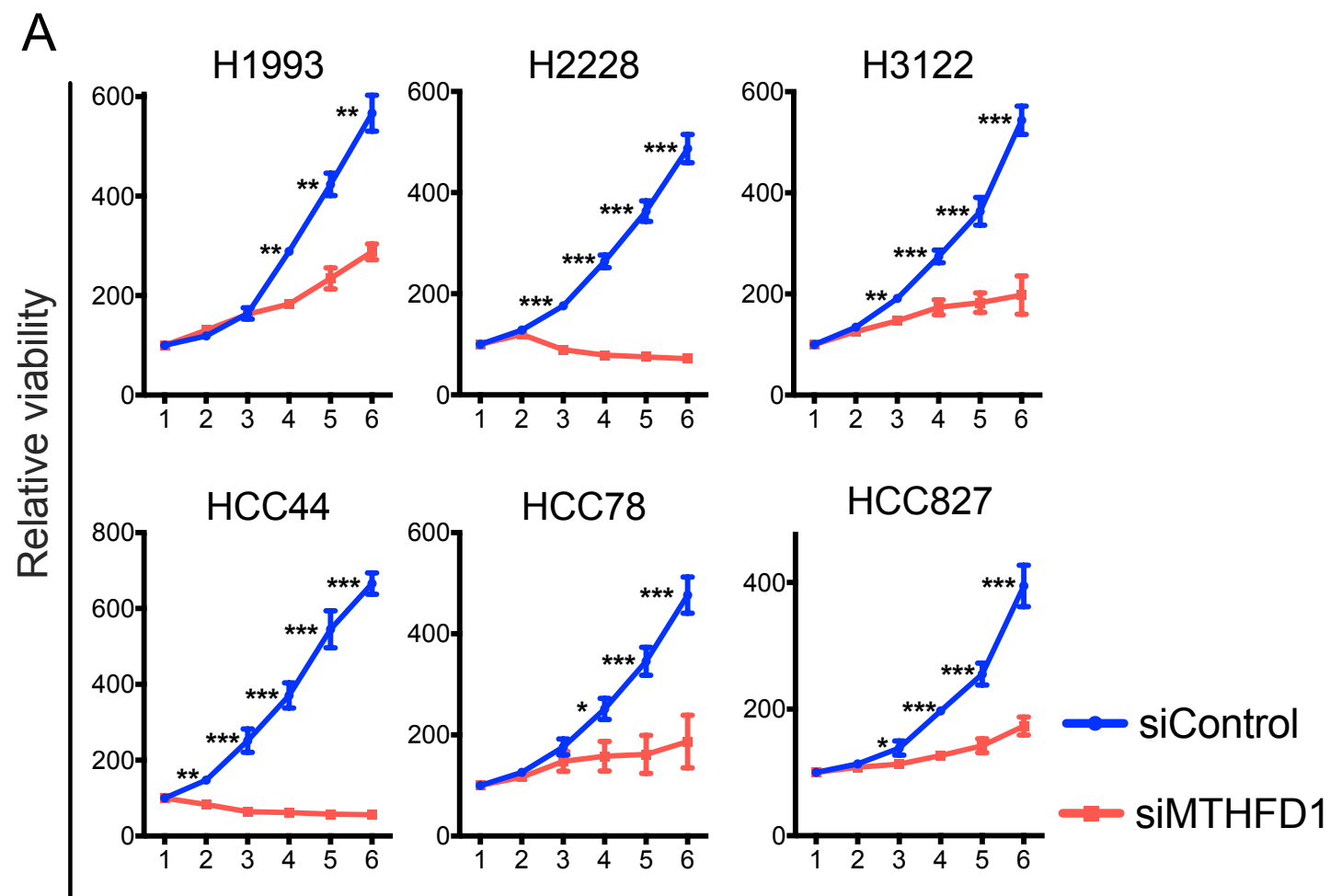

B

Time (day)

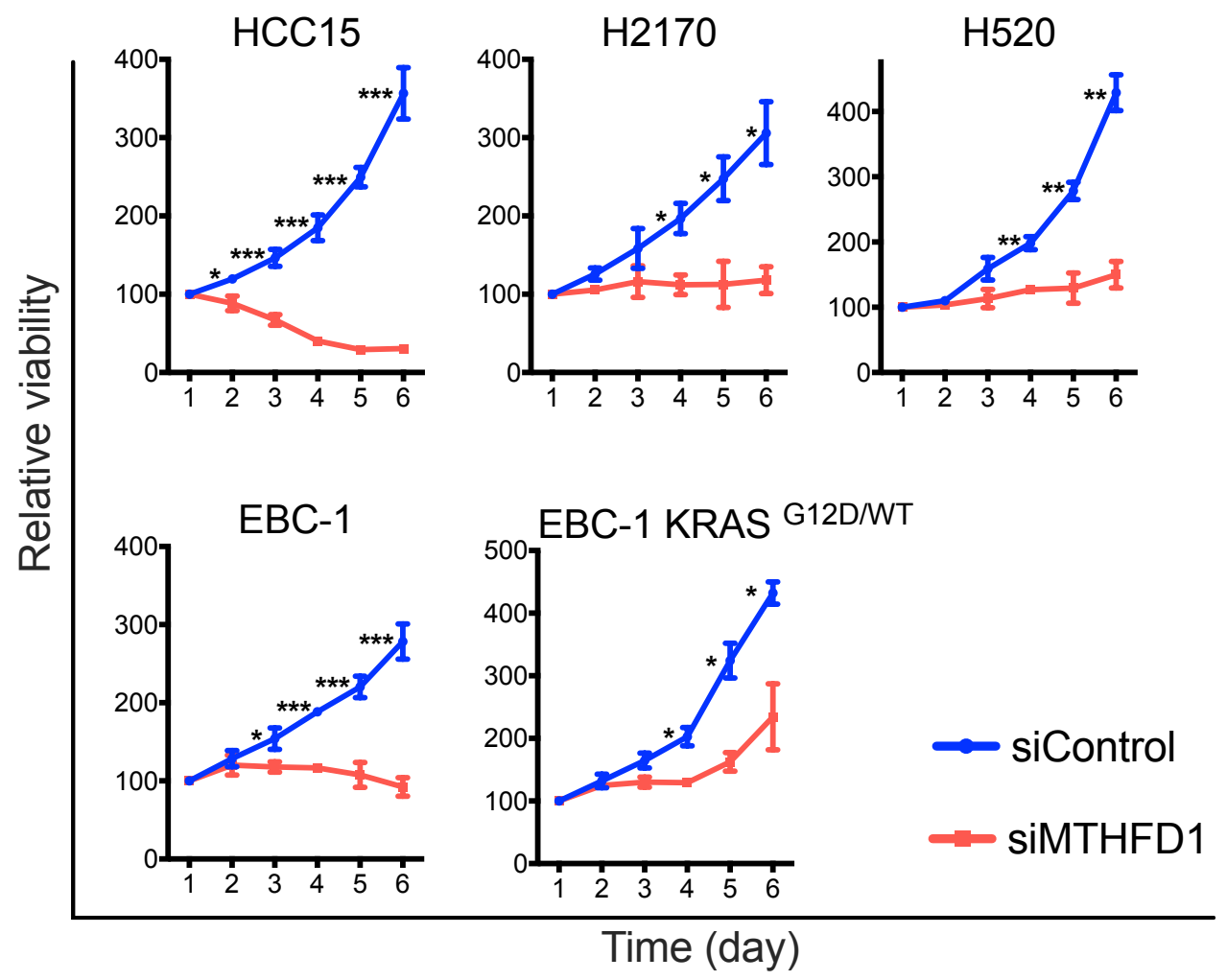




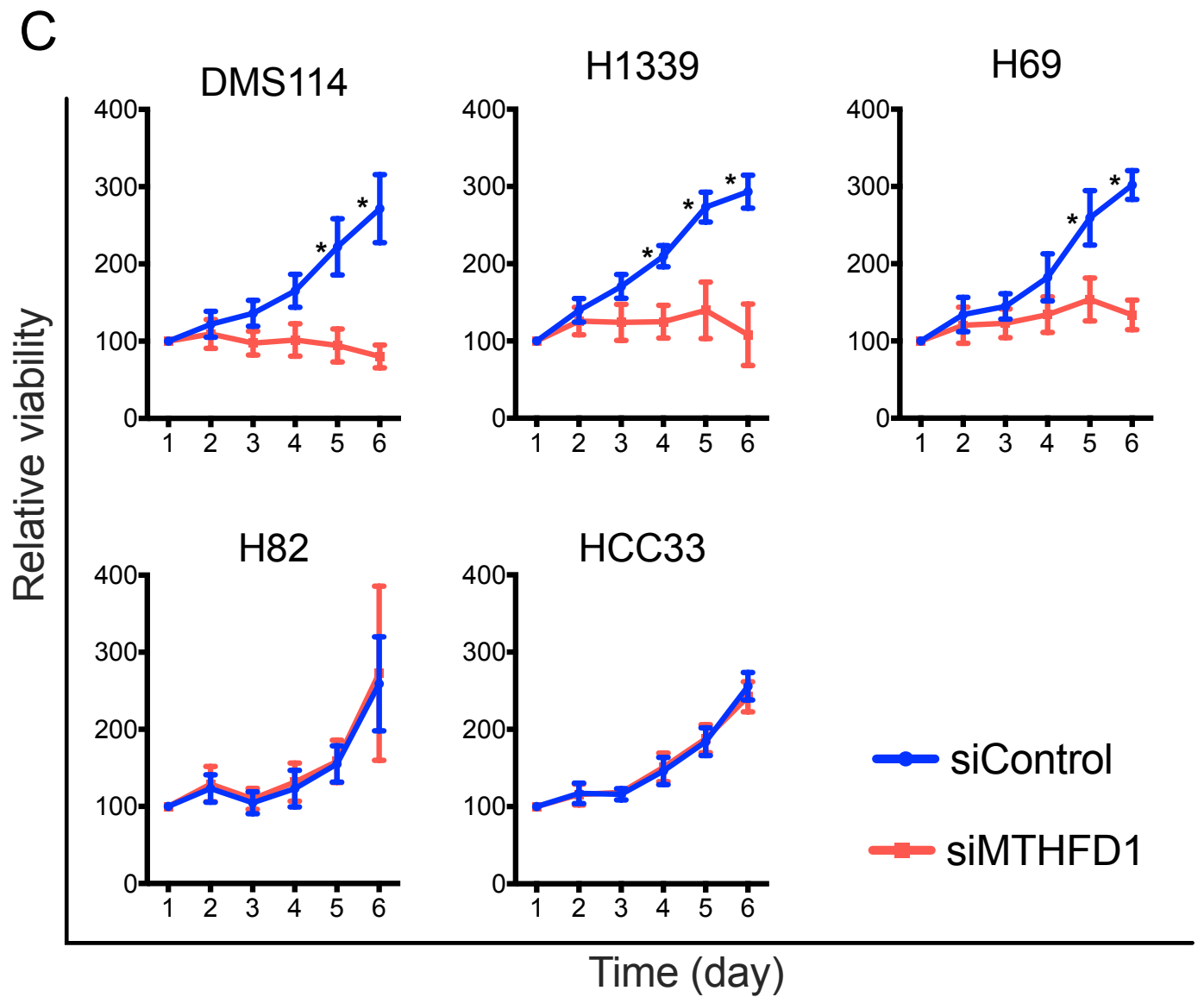

Figure 17: Knockdown of MTHFD1 significant reduced cell proliferation of lung cancer cell lines. Cell viability assays showing the cell proliferation of the $A C(A)$, SQCLC (B) ,SCLC cell lines (C) after transfecting of siRNA against MTHFD1 or control SiRNA (the data are represented as mean \pm SEM of at least three independent experiments with three technical replicates each, two-tailed Student's t-test: ${ }^{*} P<0.05$, ${ }^{*}$ $\left.P<0.01,{ }^{* * *} P<0.001\right)$.

\subsubsection{TYMS enzyme in human lung cancer cell lines.}

Western blot analysis indicated that TYMS protein was widely expressed in AC, SQCLC and SCLC cell lines (Figure $18 \mathrm{~A}$ ). ImageJ software was used to normalize the western blot bands and results were presented in figure $18 \mathrm{~B}$. TYMS protein was expressed in all human lung cancer cell lines but in various degree. Among AC cell lines, $\mathrm{HCC} 44$ and $\mathrm{H} 2228$ were the two with the highest expression. Among SCLC cell lines, $\mathrm{H} 82$ and HCC33 were the two with the highest expression. TYMS protein expression in the SQCLC cell line H520 was higher than all other human lung cancer cell lines. Next, all cell lines were 
transfected with TYMS siRNA or control siRNA for $96 \mathrm{~h}$, western blot analysis were performed to verify TYMS protein expression was remarkably decreased by TYMS siRNA in comparison to control siRNA (Figure $18 \mathrm{C}$ ).

Furthermore, cell proliferation was accessed using cell viability assay. Cells were seeded in 96 well plates and treated with TYMS siRNA or control siRNA. Cell proliferation of all AC cell lines was severely inhibited by TYMS siRNA starting from day 3 or day 4 in comparison to control siRNA and decreased to $50.0 \%$ at day 6 (Figure 19 A). Cell proliferation of SQCLC cell lines HCC15 and EBC-1 was significantly decreased from day 3 to less than $50.0 \%$ at day 6. Cell proliferation of the EBC-1 KRAS ${ }^{G 12 D / W T}$ cell line was significantly inhibited from day 5 and by $50.0 \%$ at day 6 . TYMS siRNA showed no impact on the remaining SQCLC cell lines (Figure 19 B). In SCLC cell lines, only cell proliferation of the DMS114 and $\mathrm{H} 1339$ cell line was significantly inhibited to $50.0 \%$ at day 6 (Figure $19 \mathrm{C}$ ). 


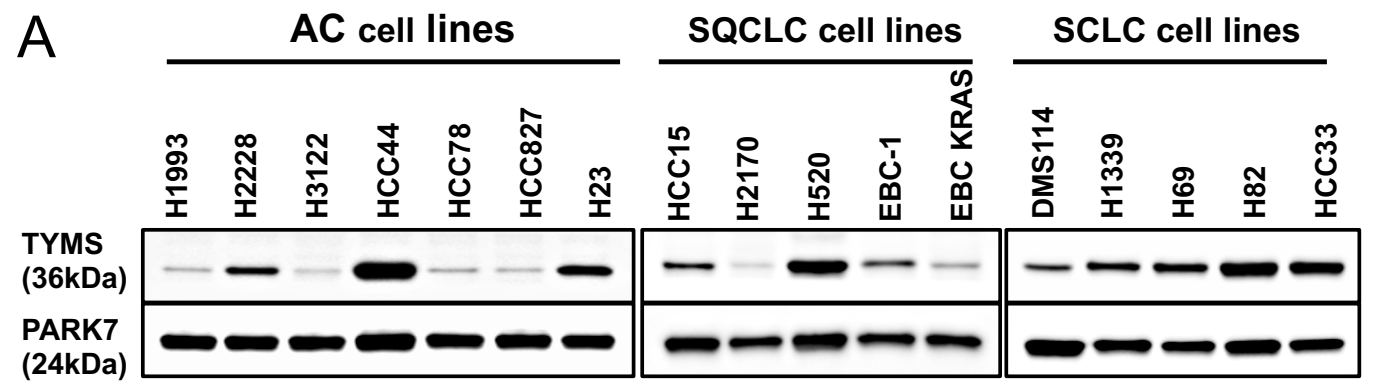

B

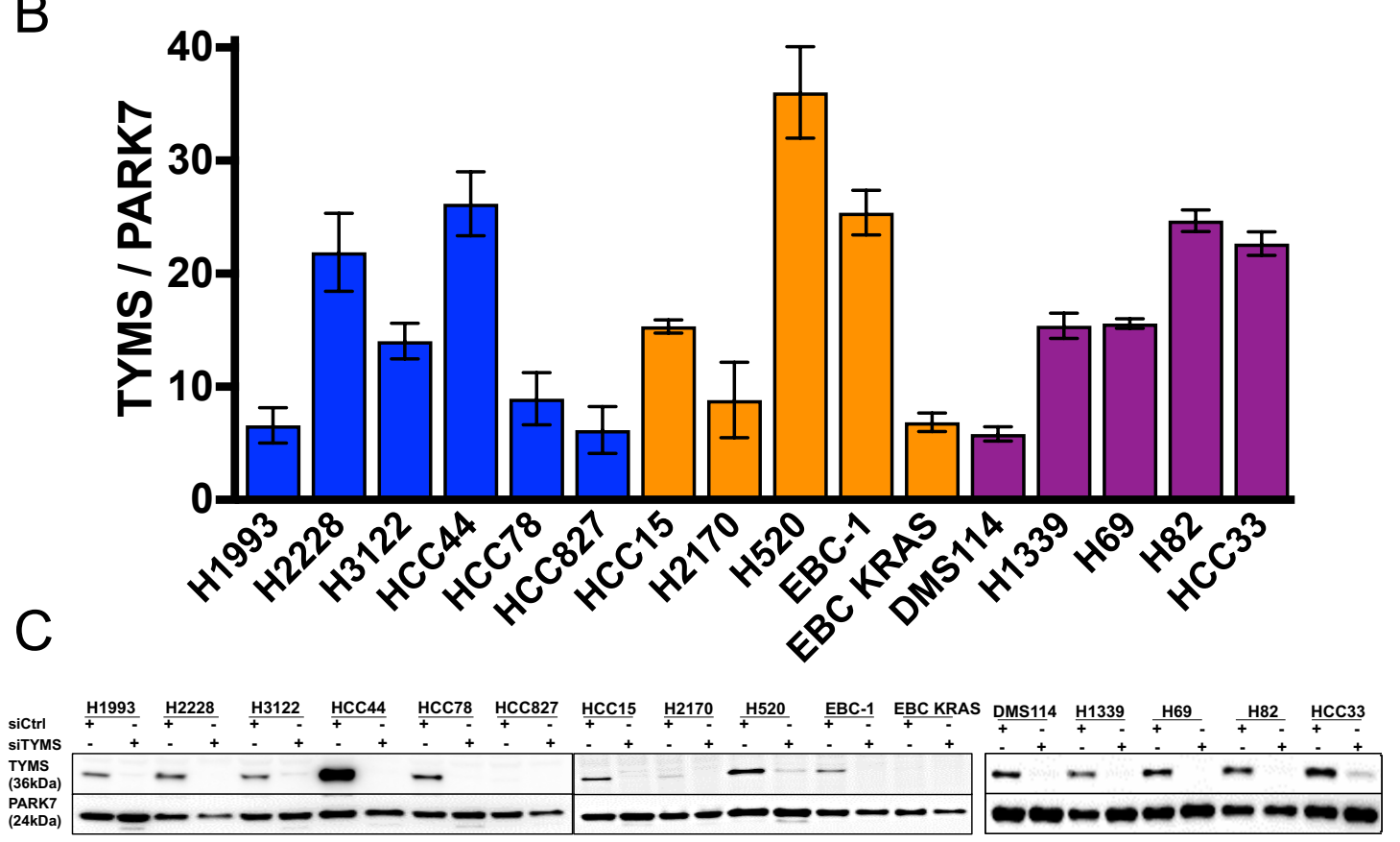

Figure 18: Expression of TYMS in human lung cancer cell lines. (A). Western blot analysis showing the expression of TYMS protein in AC, SQCLC and SCLC cell lines. PARK7 used as loading control. Relative molecular mass in kDa is shown on the left. The pictures are representative of three independent experiments. (B). Signal intensities of TYMS from AC, SQCLC and SCLC cell lines were normalized to PARK7 using ImageJ (the data are represented as mean $\pm S E M$ of three independent experiments). (C). Western blot analysis showing the effect of control siRNA and TYMS siRNA on expression of TYMS at protein lever in AC, SQCLC and SCLC cell lines after transfecting for $96 \mathrm{~h}$. 

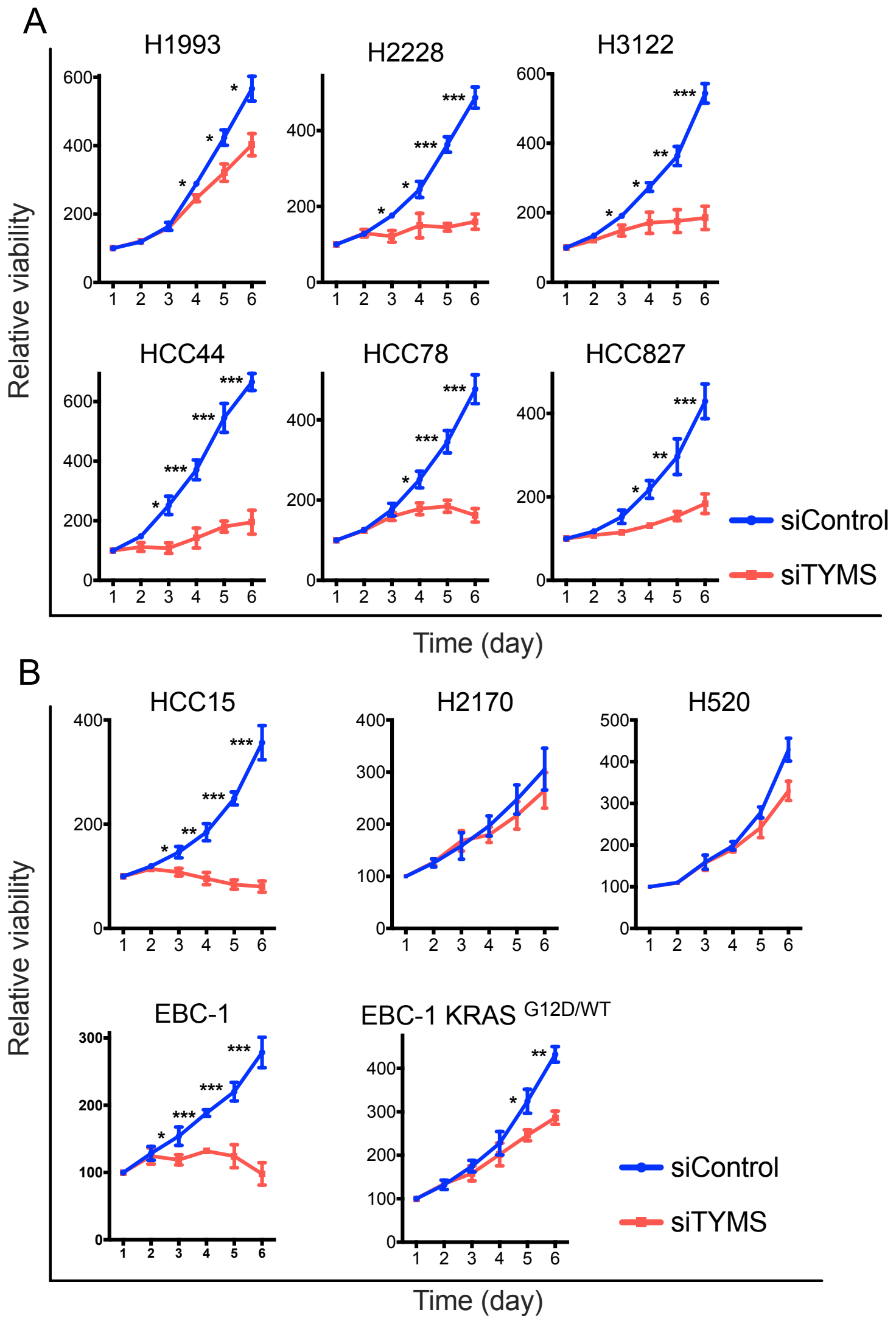


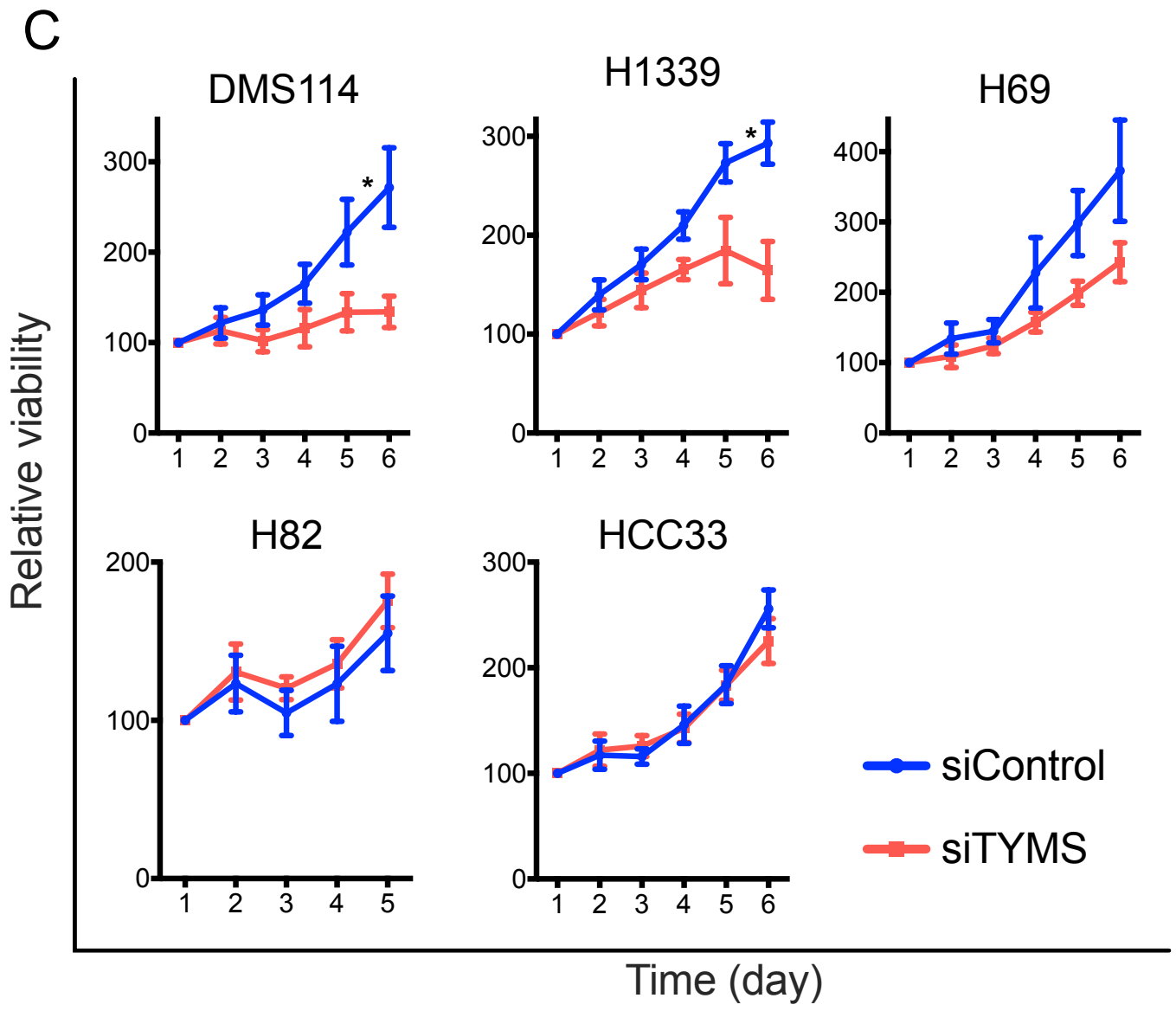

Figure 19: Knockdown of TYMS significant reduced cell proliferation of lung cancer cell lines. Cell viability assays showing the cell proliferation of the $A C(A)$, SQCLC (B), SCLC cell lines (C) after transfecting of siRNA against TYMS or control SiRNA (the data are represented as mean \pm SEM of at least three independent experiments with three technical replicates each, two-tailed Student's t-test: ${ }^{*} P<0.05,{ }^{* *}$ $\left.P<0.01,{ }^{* * *} P<0.001\right)$.

\subsection{Association between one-carbon metabolism enzymes and cytotoxic responsiveness to cisplatin and pemetrexed in human lung cancer cell lines}

Chemotherapy is the basic treatment for patients with lung cancer. Cisplatin and pemetrexed are the first-line medications. As we found that expression of one-carbon metabolism enzymes correlated with overall survival for patients with lung cancer, we further investigated the correlation between one-carbon metabolism enzymes and cytotoxic responsiveness to cisplatin and pemetrexed in human lung cancer cell lines. Cell viability assays were 
performed to evaluate the effects of cisplatin and pemetrexed on the viability of AC, SQCLC and SCLC cell lines. The IC50 for cisplatin and pemetrexed were calculated on the basis of dose-response curves. Afterwards, correlation analysis was used to investigate the relationship between the expression of one-carbon metabolism proteins and IC50 values of cisplatin and pemetrexed in AC, SQCLC and SCLC cell lines.

\subsubsection{Correlation of one-carbon metabolism proteins expression with cisplatin or pemetrexed sensitivity in human AC cell lines.}

To evaluate the sensitivity of AC cell lines to cisplatin or pemetrexed treatment, the IC50 of cisplatin or pemetrexed was calculated from dose-response curves in all of the six described $A C$ cell lines. As shown in figure $20 \mathrm{~A}$ and $B$, both agents reduced the cell viability in AC cell lines. The IC50 values for cisplatin ranged from $3.01 \mu \mathrm{M}$ to $12.84 \mu \mathrm{M}$ and for pemetrexed from $0.03 \mu \mathrm{M}$ to 184.20 $\mu \mathrm{M}$ (Table 8). HCC44 and HCC827 showed the strongest resistance to pemetrexed (Figure $20 \mathrm{~B})$. Even at the highest concentration $(50 \mu \mathrm{M})$, pemetrexed only inhibited $\mathrm{HCC} 44$ and $\mathrm{HCC} 827$ cell viability by less than $5.0 \%$ whereas cisplatin decreased cell viability by $80.0 \%$ at $5 \mu \mathrm{M}$. $\mathrm{HCC} 78$ and $\mathrm{H} 1993$ showed the best response to pemetrexed (Figure $20 \mathrm{~B}$ ). Cell viability decreased to less than $50.0 \%$ at $0.05 \mu \mathrm{M}$.

Afterwards, we performed a Pearson's correlation analysis of one-carbon metabolism proteins expression with drug sensitivity in these lines and revealed that expression of MTHFD2 significantly and reciprocally correlated with pemetrexed resistance, with a Pearson coefficient of $r=0.871(P=0.024$, Figure $20 \mathrm{D}$ ), indicating that the expression of MTHFD2 protein was associated with pemetrexed resistance in lung AC cell lines. However, correlation between the expression of MTHFD2 and IC50 of cisplatin was not significant (Figure 20

C). Moreover, there were no correlation between expression of PGDH3, SHMT2, MTHFD1, TYMS the and IC50 of cisplatin and pemetrexed (Figure 20 C, D) 
Table 8: IC50 values of cisplatin and pemetrexed in AC cell lines

\begin{tabular}{lllll}
\hline \multicolumn{3}{l}{ Drugs } & \multicolumn{3}{l}{ Pemetrexed $(\mu \mathrm{M})$} \\
\hline & \multicolumn{2}{l}{ Cisplatin $(\mu \mathrm{M})$} & IC50 & $95 \% \mathrm{Cl}$ \\
$\mathrm{H} 1993$ & $\mathrm{IC} 50$ & $95 \% \mathrm{Cl}^{*}$ & 0.10 & $(0.03-0.38)$ \\
$\mathrm{H} 2228$ & 12.84 & $(11.03-14.96)$ & 0.42 & $(0.08-6.90)$ \\
$\mathrm{H} 3122$ & 3.28 & $(2.27-4.68)$ & 0.28 & $(0.09-1.01)$ \\
$\mathrm{HCC} 44$ & 10.70 & $(9.37-12.22)$ & 0.28 \\
$\mathrm{HCC78}$ & 1.88 & $(1.56-2.26)$ & 184.20 & $(116.20-354.60)$ \\
$\mathrm{HCC} 827$ & 3.01 & $(2.12-4.25)$ & 0.03 & $(0.01-0.06)$ \\
\hline
\end{tabular}

*: $95 \%$ confidence intervals 
A

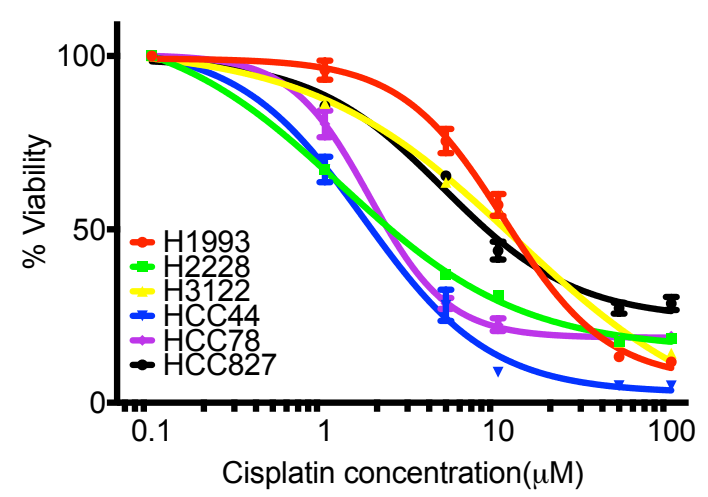

C
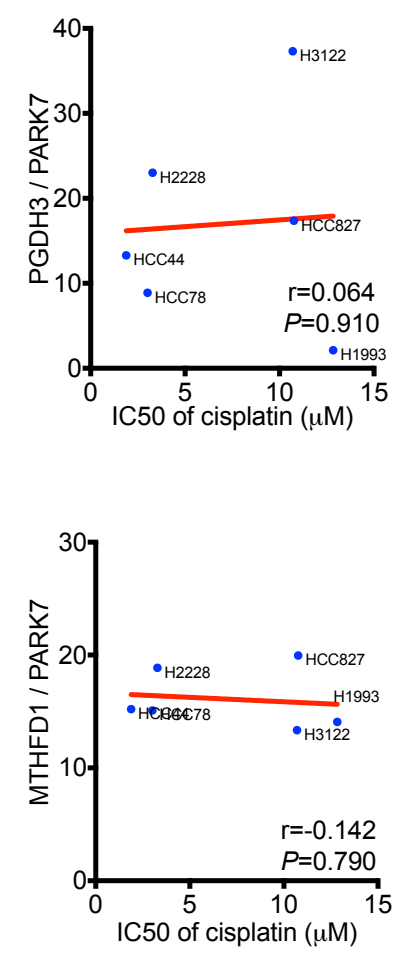

B

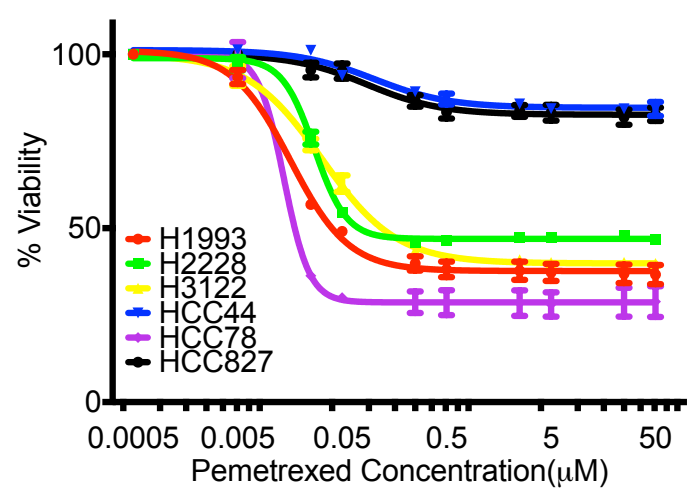

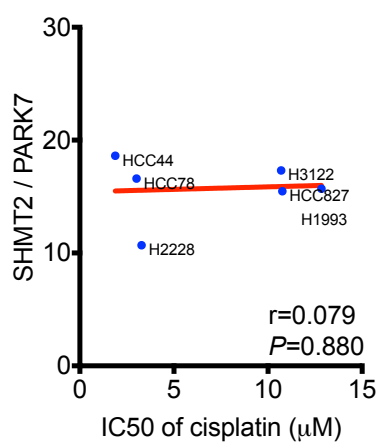
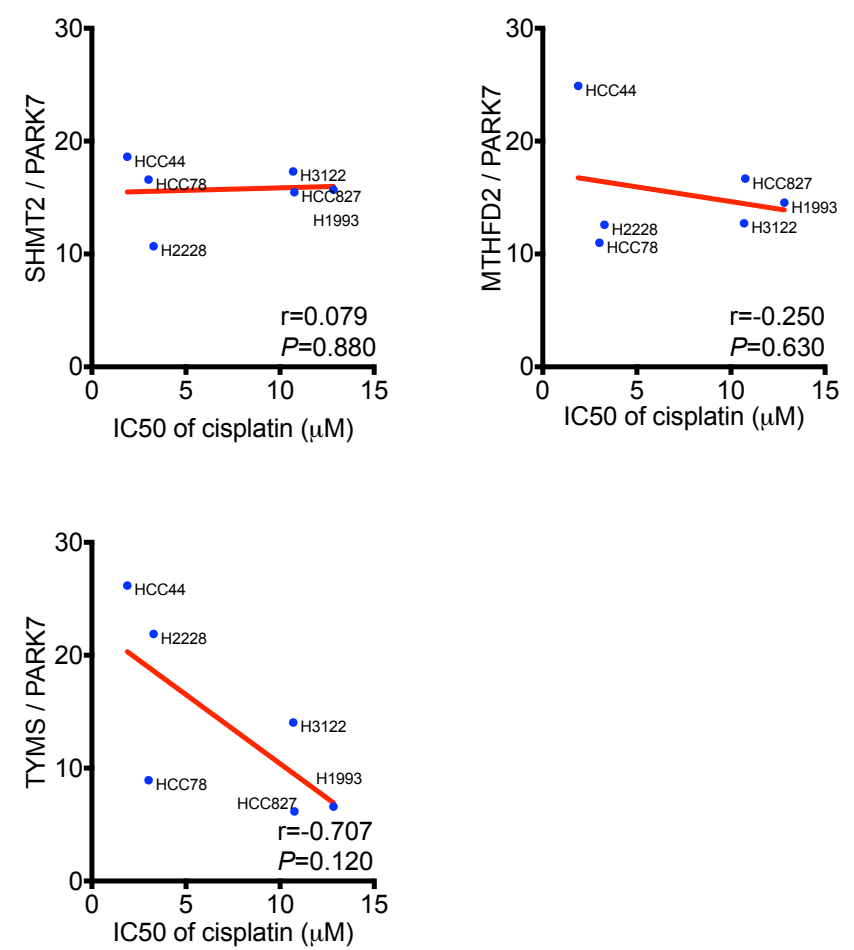
D
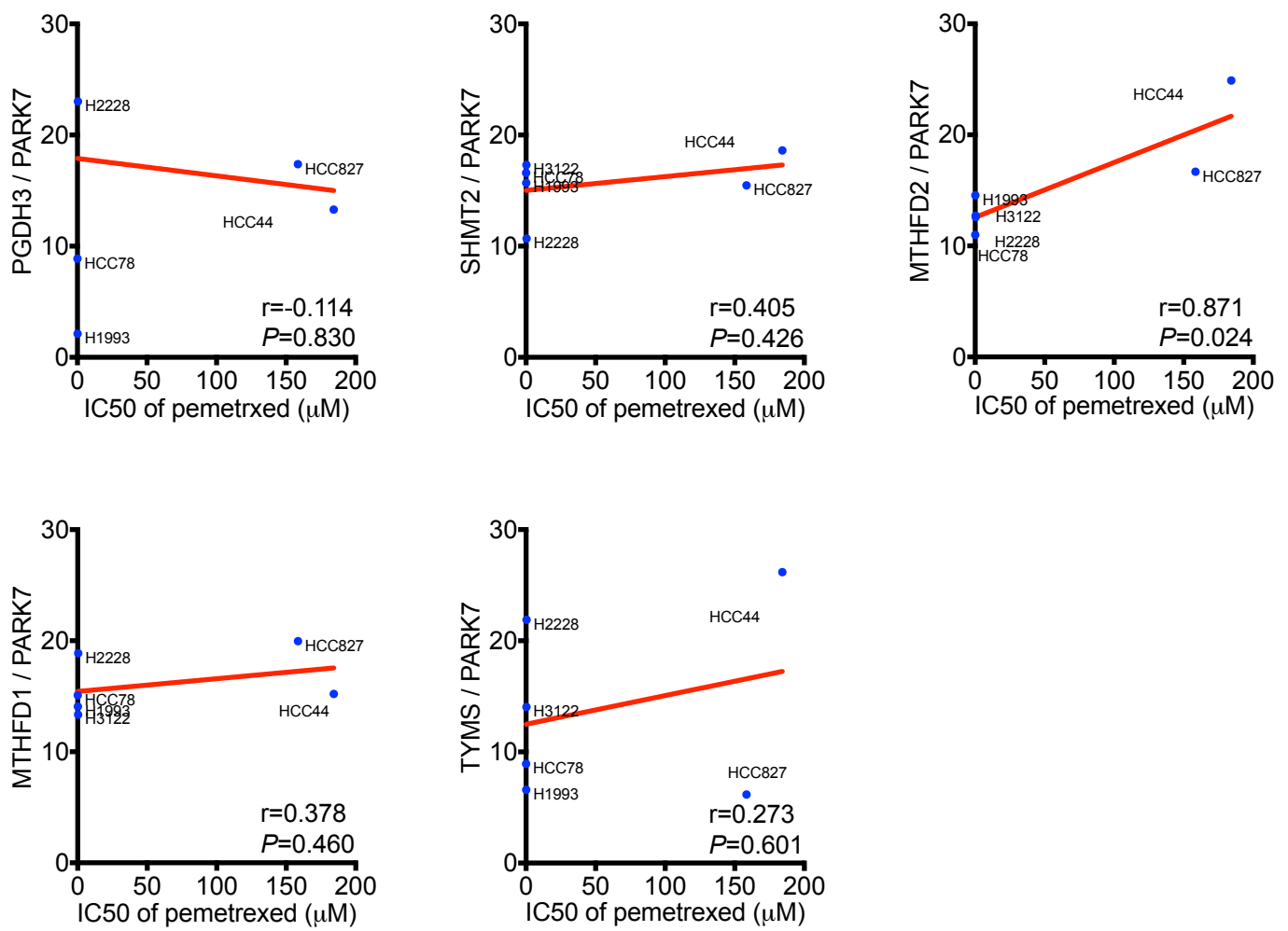

Figure 20: Correlation of one-carbon metabolism proteins expression with cisplatin or pemetrexed sensitivity in AC cell lines. Inhibitory dose-response curves for $A C$ cell lines treated with cisplatin $(A)$ for $72 \mathrm{~h}$ and pemetrexed $(B)$ for $96 \mathrm{~h}$ are shown. The dots and bars represent as mean \pm SEM of at least three independent experiments with three technical replicates each. (C and D). Pearson's correlation analyses of onecarbon metabolism protein expression with drug sensitivity are shown. Correlation curves show the correlation between the IC50 values of cisplatin (C) and pemetrexed (D) and the expression of one-carbon metabolism proteins in relation to loading control as obtained by western blot analysis.

\subsubsection{Correlation of one-carbon metabolism proteins expression with cisplatin or pemetrexed sensitivity in human SQCLC cell lines.}

To evaluate the sensitivity of SQCLC cell lines to cisplatin or pemetrexed treatment, the IC50 of cisplatin or pemetrexed was calculated from doseresponse curves in all of the five described SQCLC cell lines. All SQCLC cell lines showed good response to cisplatin (Figure $21 \mathrm{~A}$ ) but were resistant against pemetrexed (Figure $21 \mathrm{~B}$ ). Cisplatin significantly inhibited cell viability of all SQCLC cell lines by $80.0 \%$, pemetrexed only inhibited cell viability by 
less than $50.0 \%$ except for H520. The IC50 values of cisplatin and pemetrexed in SQCLC cell lines were calculated and represented in table 9 on the basis of dose-response curves: the IC50 values of cisplatin ranged from $4.41 \mu \mathrm{M}$ to $23.98 \mu \mathrm{M}$ and from $1.62 \mu \mathrm{M}$ to $70.79 \mu \mathrm{M}$ for pemetrexed. There was no correlation between one-carbon metabolism protein expression and drug sensitivity by Pearson's correlation analysis in SQCLC cells (Figure $21 \mathrm{C}, \mathrm{D}$ ).

Table 9: IC50 values of cisplatin and pemetrexed in SQCLC cell lines

\begin{tabular}{|c|c|c|c|c|}
\hline & \multicolumn{4}{|c|}{ Drugs } \\
\hline & \multicolumn{2}{|c|}{ Cisplatin $(\mu \mathrm{M})$} & \multicolumn{2}{|c|}{ Pemetrexed $(\mu \mathrm{M})$} \\
\hline & IC50 & $95 \% \mathrm{Cl}$ * & IC50 & $95 \% \mathrm{Cl}$ \\
\hline HCC15 & 23.98 & $(18.33-31.40)$ & 70.79 & $(35.07-170.40)$ \\
\hline H2170 & 4.41 & $(3.87-5.02)$ & 59.98 & $(24.76-179.10)$ \\
\hline H520 & 11.21 & $(9.08-13.87)$ & 1.624 & $(0.82-3.23)$ \\
\hline EBC-1 & 27.26 & $(24.17-30.73)$ & 30.66 & $(8.51-89.73)$ \\
\hline $\mathrm{EBC}-1 K R A S^{G 12 D / W T}$ & 16.53 & $(11.33-24.37)$ & 28.35 & (8.59-77.65) \\
\hline
\end{tabular}

*: $95 \%$ confidence intervals 
A

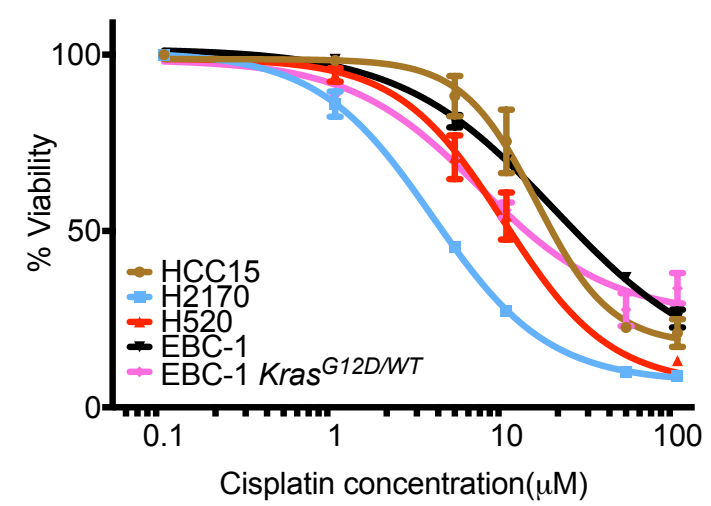

B

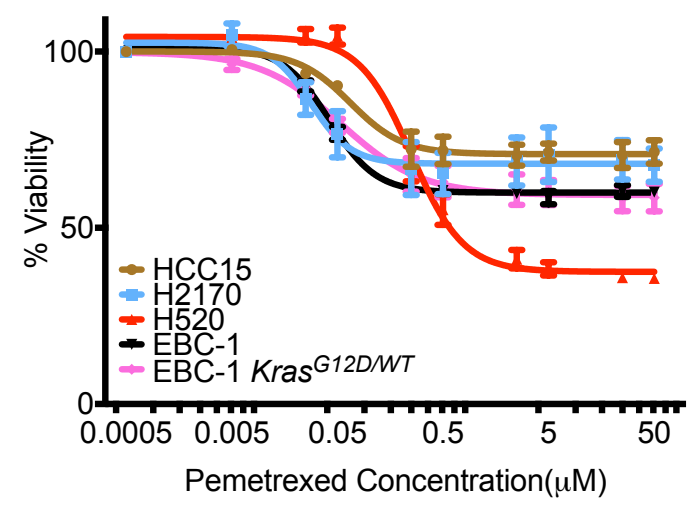

C
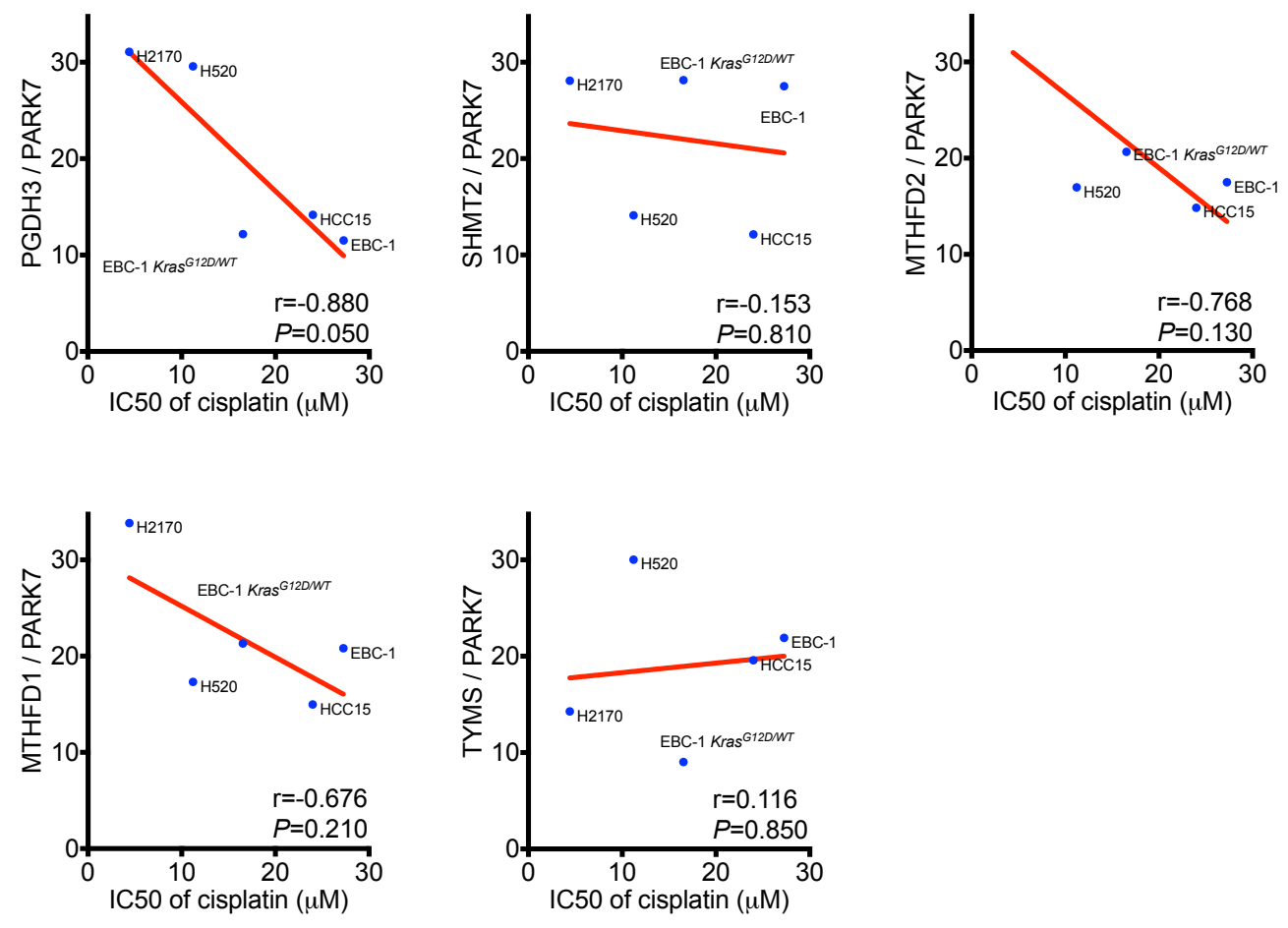

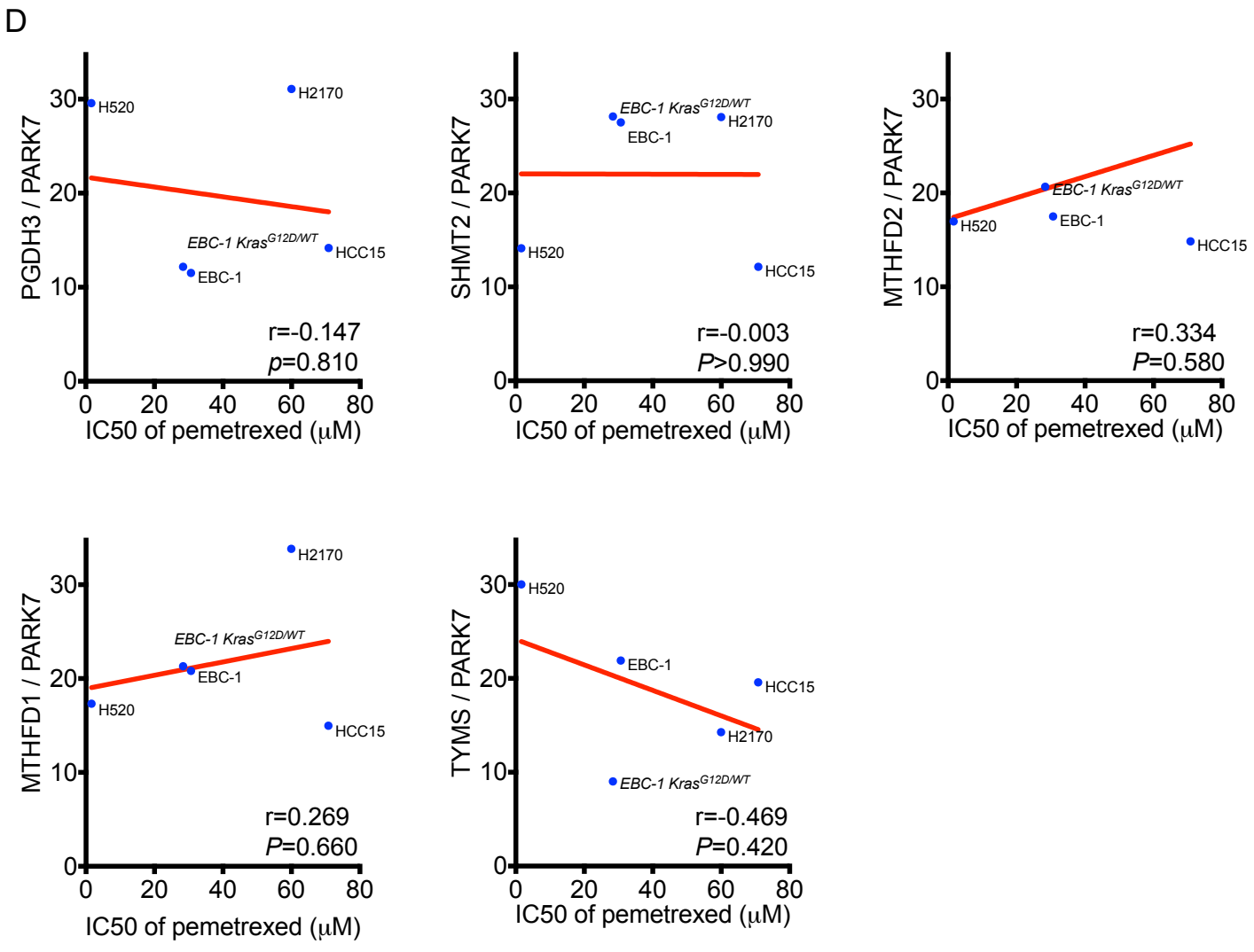

Figure 21: The expression of one-carbon metabolism protein is not associated with chemoresistance in SQCLC cell lines. Inhibitory dose-repose curves show the SQCLC cell lines treated with cisplatin (A) for $72 \mathrm{~h}$ and pemetrexed $(B)$ for $96 \mathrm{~h}$. The dots and bars represent the mean $\pm S E M$ of at least three independent experiments, each with three technical replicates. Correlation curves show the correlation between the IC50 values of cisplatin (C) and pemetrexed (D) and the expression of one-carbon metabolism proteins in SQCLC cell lines.

\subsubsection{Correlation of one-carbon metabolism proteins expression with cisplatin or pemetrexed sensitivity in human SCLC cell lines.}

To evaluate the sensitivity of SCLC cell lines to cisplatin or pemetrexed treatment, the IC50 of cisplatin or pemetrexed was calculated from dose-response curves in all of the five described SQCLC cell lines. Cell viability of SCLC cell lines was strongly inhibited by treatment of cisplatin except H69 (Figure 22 A). Cisplatin inhibited cell viability of $\mathrm{H} 69$ by only $40.0 \%$ even at the highest concentration $(100 \mu \mathrm{M})$. SCLC cell lines showed resistance to pemetrexed (Figure $22 \mathrm{~B}$ ), although DMS114 could be inhibited by $60.0 \%$ at the highest concentration of pemetrexed $(50 \mu \mathrm{M})$. The IC50 values of cisplatin and pemetrexed were 
calculated and shown in table 10 according to dose-response curves: the IC50 of cisplatin ranged from $2.96 \mu \mathrm{M}$ to $15.58 \mu \mathrm{M}$ and from $0.22 \mu \mathrm{M}$ to $65.66 \mu \mathrm{M}$ for pemetrexed. Subsequently, we used a Pearson's correlation analysis and found that expression of SHMT2 significantly and reciprocally correlated with cisplatin resistance ( $r=0.926, P=0.024$ ) (Figure $22 \mathrm{C}$ ). However, we did not observe a significant correlation between one-carbon metabolism proteins expression and the response to pemetrexed in SCLC cell lines (Figure $22 \mathrm{D}$ ).

Table 10: IC50 values of cisplatin and pemetrexed in SCLC cell lines

\begin{tabular}{lllll}
\hline \multicolumn{3}{l}{ Drugs } \\
& \multicolumn{2}{l}{ Cisplatin $(\mu \mathrm{M})$} & \multicolumn{2}{l}{ Pemetrexed $(\mu \mathrm{M})$} \\
\hline \multirow{2}{*}{ DMS114 } & IC50 & $95 \% \mathrm{Cl}^{*}$ & IC50 & $95 \% \mathrm{CI}$ \\
\cline { 2 - 5 } H1339 & 6.79 & $(5.64-8.17)$ & 0.22 & $(0.10-0.50)$ \\
H69 & 2.96 & $(2.44-3.57)$ & 4.02 & $(0.82-21.46)$ \\
H82 & 53.73 & $(20.00-132.20)$ & 47.31 & $(16.84-147.80)$ \\
HCC33 & 3.70 & $(2.24-5.91)$ & 58.39 & $(23.33-188.50)$ \\
\hline
\end{tabular}

*: $95 \%$ confidence intervals 
A

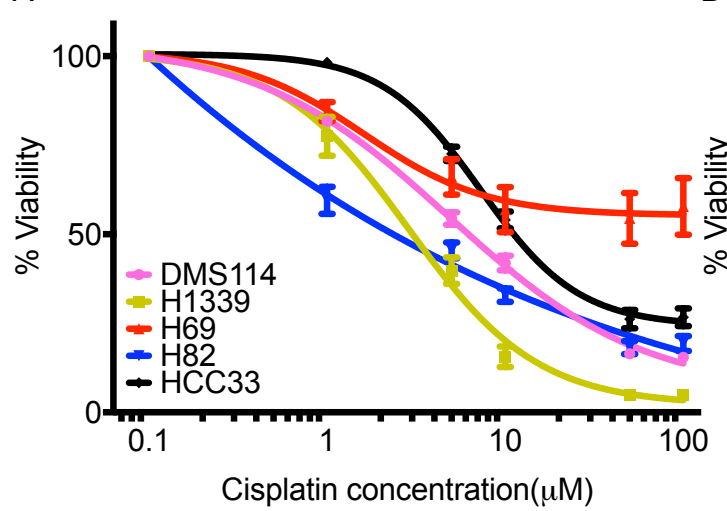

C
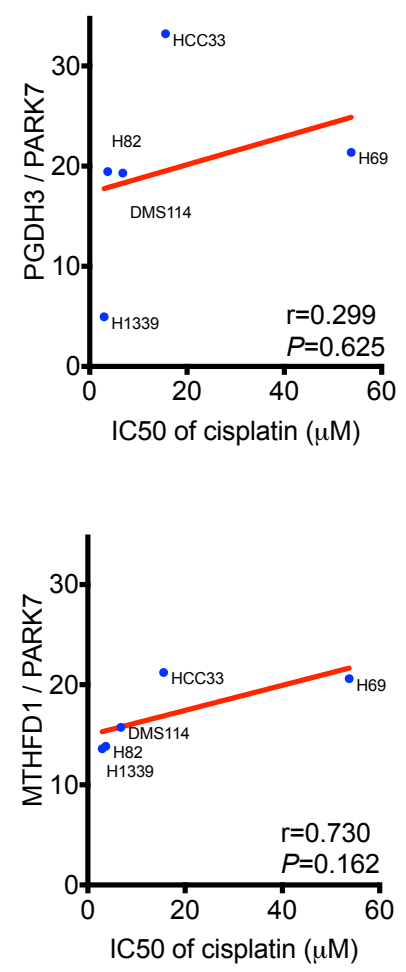

B

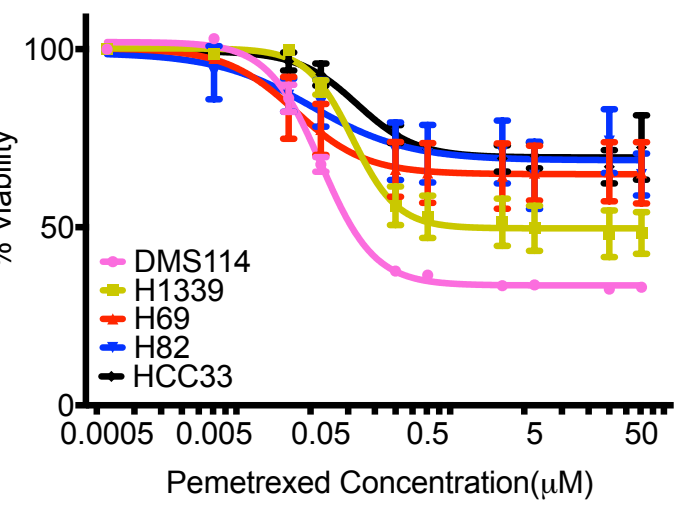

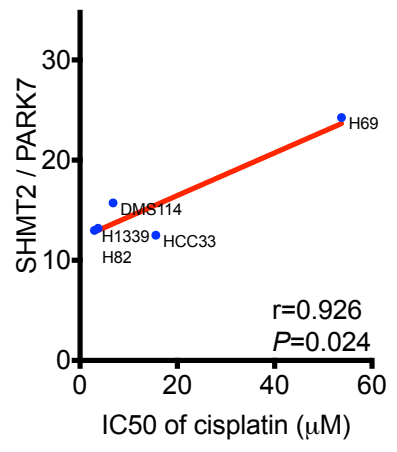

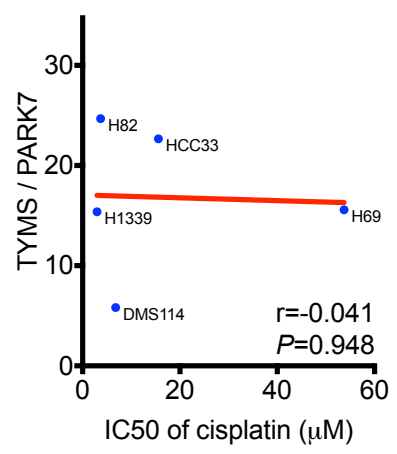

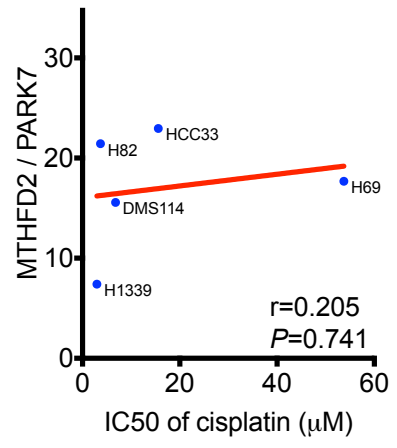

IC50 of cisplatin $(\mu \mathrm{M})$ 

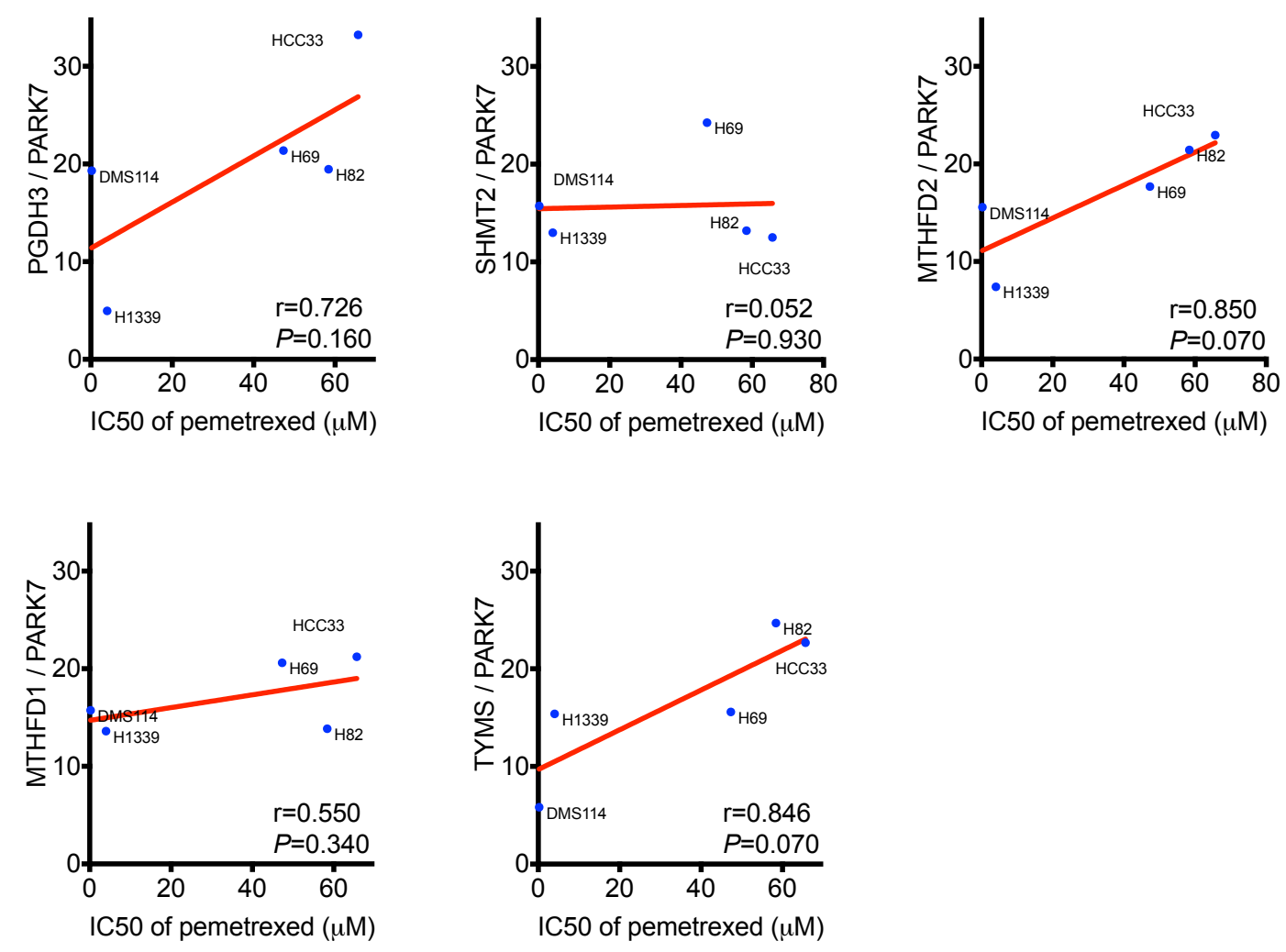

Figure 22: Correlation of one-carbon metabolism proteins expression with cisplatin or pemetrexed sensitivity in SCLC cell lines. Inhibitory dose-repose curves show the SCLC cell lines treated with cisplatin (A) for $72 \mathrm{~h}$ and pemetrexed (B) for $96 \mathrm{~h}$. The dots and bars represent the mean \pm SEM of at least three independent experiments, each with three technical replicates. Correlation curves show the correlation between the IC50 values of cisplatin (C) and pemetrexed (D) and the expression of one-carbon metabolism proteins in SCLC cell lines. 


\section{Discussion}

The hyperproliferation of cancer cells commonly points to a high requirement on one-carbon metabolism, which could be developed as anticancer target. For example, the anti-folate drug aminopterin was already used successfully for acute lymphoblastic leukemia (ALL) in children in 1948 (Farber and Diamond 1948). Today, chemical variants of driven folate antagonists chemotherapeutic agents and are used to treat several cancer types by FDA approving (Locasale 2013) including lung cancer, ALL, breast cancer, bladder cancer and lymphomas (Chabner and Roberts 2005; Locasale 2013; Vander Heiden 2011).

A study pointed that the capacity of cell growth and proliferation is associated with cancer cells reprogram one-carbon metabolism (Boroughs and Deberardinis 2015). For example, PGDH3, the rate-limiting enzyme for serine synthesis, has been implicated in multiple cancers such as breast cancer, melanomas and NSCLC tumors (Denicola et al. 2015; Locasale et al. 2011; Maddocks et al. 2013; Possemato et al. 2011; Zhang et al. 2017). MTHFD2, a crucial enzyme in mitochondrial metabolism, indicated with a poor prognosis in breast cancer (Jain et al. 2012), hepatocellular carcinoma (Liu et al. 2016), pancreatic cancer (Noguchi et al. 2018) and a study showed that abolishment of MTHFD in vitro strongly inhibits remote metastasis of melanoma cells (Piskounova et al. 2015).

Hence, we first assessed the expression of one-carbon enzyme proteins by immunohistochemistry in human lung cancer specimens and showed that MTHFD2 and PGDH3 were strongly expressed in the three major lung cancer subtypes AC, SQCLC, and SCLC. Furthermore, MTHFD2 and PGDH3 expression were correlated with poor prognosis in patients with pulmonary adenocarcinoma, supporting previous studies in human pancreatic cancer, breast cancer, hepatocellular carcinoma (Liu et al. 2014; Liu et al. 2016; Song et al. 2018). Interestingly, although positive MTHFD2 staining was more frequent in SQCLC (81.2\%) and SCLC (81.6 \%) than in AC cases $(50.0 \%)$, there was no correlation with prognosis in patients with SQCLC or SCLC. Surprisingly, residual one-carbon metabolic marks were not associated with overall survival in three subtypes of lung cancer. 
Given that MTHFD2 within mitochondrial one-carbon metabolism can catalyze the $\mathrm{NAD}^{+}$dependent reactions (Tibbetts and Appling 2010). The folate cycle directly produces the nicotinamide adenine dinucleotide phosphate hydrogen and also it intersects with the methionine cycle to contribute product of glutathione (Maddocks et al. 2013).

In addition, several studies showed that enzymes level of the folate cycle correlate with oncogenes such as KRAS, MYC. For example, upregulation of the folate metabolism enzyme MTHFD2 in NSCLC cells with KRAS-mutant may be found a higher anti-folate activity (Moran et al. 2014). A report showed mTORC1, stimulating the mTHF cycle, provides one-carbon units to MTHFD2 to promote a production of purine nucleotides and contribute to affect cell growth (Ben-Sahra et al. 2016).

To study the expression and function of one-carbon metabolism enzymes in vitro, we used sixteen human lung cancer cell lines (six AC, five SQCLC and five SCLC) which recapitulate the histological classification. We analyzed the sensitivity of the three lung cancer subtypes to pemetrexed. Pemetrexed, is a novel anti-folate agent which inhibits THF cofactor-dependent enzymes, and is approved for the treatment of lung cancer and selected for some solid tumors like breast cancer (Chattopadhyay et al. 2007). As expected, our findings revealed that MTHFD2 expression in AC cell lines was correlated with sensitivity to pemetrexed. It is evident that the MTHFD2 result obtained here was in exceptionally good agreement with existing studies that gefitinib resistance depended on MTHFD2-mediated mitochondrial one carbon metabolism (Nishimura et al. 2019). Although MTHFD2 was markedly expressed in SQCLC and SCLC cell lines, there were no association between MTHFD2 protein levels and sensitivity to pemetrexed. This suggested that cell survival of AC cell lines may be particularly dependent on mitochondrial folate metabolism enzymes.

Additional, SHMT2, another mitochondrial one-carbon metabolism enzyme that is frequently overexpressed in lung cancer produces catalytically the glycine (Nilsson et al. 2014) which acts as substrate for MTHFD2 in one-carbon cycle. Accumulating evidence showed that SHMT2 expression is significantly increased in cancers such as ovarian cancer, breast cancer, colorectal cancer 
and correlates with poor prognosis (Lee et al. 2014; Wang et al. 2017; Zhang et al. 2016). SHMT2 in vitro knockdown was associated with a reduction of cell proliferation and an inhibition of tumorigenicity in hepatocellular cancer cell lines (Woo et al. 2016). A synergistic effect of MTHFD2 (mitochondrial) and SHMT1 (cytosolic) in inhibiting colorectal carcinoma growth in vivo (Ducker et al. 2016) has been shown. However, we did not detect any correlation between SHMT2 expression and IC50 of pemetrexed in AC cell lines. Zhang et al. (2012) showed that glycine decarboxylases, such as PSAT1, PSPH, and SHMT1 and 2 do not significantly promote glycine uptake but promote glycolysis instead in NIH/3T3 cells with ectopic expression of SHMT, indicating a synergism between one-carbon metabolism and other metabolic pathways.

Cisplatin, an inhibitor of nucleotide metabolism and a well-known chemotherapeutic drug in various tumors, leads to death of cancer cells by interfering with the biosynthesis of cytidine, inhibition of ribonucleotide reductase (RNR) and preventing the formation of deoxynucleotides damaging DNA (Jamieson and Lippard 1999; Nilsson et al. 2014; Zamble and Lippard 1995). Hence, we also evaluated the relationship of one-carbon metabolism enzymes with the response to cisplatin but did not find any correlation in the tested cell lines.

Next, we used small interfering RNAs against PGDH3, SHMT2, MTHFD2, MTHFD1 and TYMS to study the impact of these enzymes on cell proliferation. We demonstrated the MTHFD2 gene strongly influenced cell proliferation in lung cancer. As described in the results section, cell proliferation decreased by $50.0 \%$ in all AC and SQCLC cell lines and in 3 of 5 SCLC cell lines upon knockdown of MTHFD2. Moreover, it was observed in colon cancer and glioblastomas that cell proliferation and survival depend on MTHFD2 (Gustafsson et al. 2015; Nilsson et al. 2014).

Recent research revealed that MTHFD2 enhanced malignancy and distant metastasis by regulation of redox homeostasis under various stress stimuli such as hypoxia and degradation of stroma in colorectal cancer (Ju et al. 2018). MTHFD2 expression is also elevated in colorectal cancer (CRC) and correlates with a poor prognosis (Gustafsson et al. 2017). Specifically, the first inhibitor of 
MTHFD2 LY345899 significantly inhibits the colorectal cancer growth, promising a potential therapeutic agent for CRC treatment (Ju et al. 2018).

However, the regulatory mechanism of MTHFD2 in lung cancer cells is not yet clear. First, the MTHFD2 enzyme is necessary for the production of NADPH and it has been reported that disrupting of NADPH homeostasis enhances drug-induced apoptosis (Ju et al. 2017). For example, inhibition of serineglycine biosynthesis by depletion of glutamine or PGDH3 induced apoptosis in EWS cells (Sen et al. 2018). It is well-known that SHMT2 is an important enzyme which regulates serine metabolism in mitochondria. SHMT2 knockdown produces auxotrophic effects for glycine (Zhang et al. 2012).

Ju et al. (2018) reported that MTHFD2 in CRC was transcriptionally upregulated by the oncogene cellular myelocytomatosis oncogen (c-Myc) rather than K-RAS downstream. MYC is a proto-typical oncogene which activates cell growth and proliferation, genes involved in the expression of metabolic enzymes from phosphoribosyl pyrophosphate (PRPP) to adenosine monophosphate and guanosine monophosphate in tumor-initiating cells (Wang et al. 2017) and purine and pyrimidine nucleotides biosynthesis along with inactivate apoptotic pathway (Liu et al. 2008; Pelengaris et al. 1999; Shchors et al. 2006). The RAS family encoding small enzymes that hydrolyze guanosine triphosphate belongs to the most frequently mutated group of genes in NSCLC (30.0\% of pulmonary adenocarcinomas (Ding et al. 2008) and $5.0 \%$ of squamous cell carcinomas) (Downward 2003). These tumors carry an activating RAS mutation leading to constitutive activation of the RAS-ERK signaling pathway as an essential driver of proliferation, differentiation and cellular survival. Although direct inhibition of oncogenic $R A S$ remains to be challenging in the future, MTHFD2 combining the first K-RAS inhibitor AMG 510 may be of interest as a potential therapeutic strategy.

One hypothesis is that silencing of MTHFD2 results in blockade of the cell cycle in adenocarcinoma cells. In support of this idea, MTHFD1 concentrated in the nucleus preferentially ensure to conserve thymidylate synthesis by consume other intermediate such as homocysteine in the cytoplasm lack of folate deficiency or during the cell arrest (Field et al. 2014). For example, Knockdown MTHFD1 with a specific RNA caused a strong decreased thymidylate 
synthesis, on the other side, and increased uracil integration into DNA (Field et al. 2015). Moreover, aberrant MTHFD2 in colorectal cancer cells not only promoted cell proliferation, migratory and also affected cell death (Wei et al. 2019). Serine is partiality catabolized to pyrimidine and glutathione in a group of AC with high expression of PGDH3 (Piskounova et al. 2015). In order to produce RNA and DNA, proliferating cells by upregulating pyrimidine and purine metabolism supply a competent substrate (Field et al. 2014). Elevated generation of pyrimidines and purines is required for cell division.

Cells without p53 failed to the respond to serine depletion and cell cycle arrest preventing uncontrolled proliferation (Maddocks et al. 2013). The activated p53 regulated the serine biosynthesis through reducing $\mathrm{PGDH} 3$ protein and resulting serine deprivation (Maddocks et al. 2013). The p53 mutations cause serine metabolism alteration that induced a strong decreased tumor growth in many tumors including lung cancer (Maddocks et al. 2013). Non-genotoxic stress activated the p53 suppress the PGDH3 protein expression, leading to enhancement of apoptosis in normal cells.(Kruiswijk et al. 2015). So, it is interesting that activation of $\mathrm{p} 53$ by serine starvation causes cell cycle arrest. Cell survival may be due to the serine cycle intersecting with glutathione synthesis cycle within cells (Kruiswijk et al. 2015; Maddocks et al. 2013).

In the present study, we also examined the expression of PGDH3, MTHFD1 and TYMS enzymes in human lung cancer cell lines, the correlation between expression of these enzymes and IC50 of pemetrexed or cisplatin, and cell proliferation after knockdown of these genes. The results did not reveal that expression of PGHD3, MTHFD1 or TYMS was associated with IC50 of pemetrexed and cisplatin. 


\section{Summary}

In the present study, we investigated the role of one-carbon metabolism enzymes in human lung cancer.

First, we measured the expression and prognostic impact of the one-carbon metabolism enzymes PGDH3, SHMT2, MTHFD2, MTHFD1 and TYMS in human lung cancer samples using $\mathrm{IHC}$ and found that overexpression of PGDH3 and MTHFD2 is marker of poor prognosis in patients with AC. Next, we performed experiments to investigate the function of these enzymes in lung cancer cell lines including AC, SQCLC and SCLC cells. Our results showed that knockdown of these genes significantly reduced cellular proliferation in AC cell lines but not in most SQCLC and SCLC cell lines. Expression of MTHFD2 protein is positively correlated with IC50 of pemetrexed in AC cell lines. Altogether, the phenotypes we found supported that one-carbon metabolism enzymes promote proliferation of human lung cancer cells, especially in AC.

Overall, our study revealed the diversity of one-carbon metabolism in three different subtypes of lung cancer. Specifically, MTHFD2 was identified as an independent prognostic factor and the most promising anticancer target in pulmonary adenocarcinoma. 


\section{Reference}

Adjei AA (2000): Pemetrexed: a multitargeted antifolate agent with promising activity in solid tumors. Ann Oncol $\underline{11}, 1335-1341$

Arriagada R, Dunant A, Pignon JP, Bergman B, Chabowski M, Grunenwald D, Kozlowski M, Le Pechoux C, Pirker R, Pinel MI, et al. (2010): Long-term results of the international adjuvant lung cancer trial evaluating adjuvant Cisplatin-based chemotherapy in resected lung cancer. J Clin Oncol $\underline{28}, 35-42$

Ben-Sahra I, Hoxhaj G, Ricoult SJH, Asara JM, Manning BD (2016): mTORC1 induces purine synthesis through control of the mitochondrial tetrahydrofolate cycle. Science $\underline{351}, 728-733$

Bolusani S, Young BA, Cole NA, Tibbetts AS, Momb J, Bryant JD, Solmonson A, Appling DR (2011): Mammalian MTHFD2L encodes a mitochondrial methylenetetrahydrofolate dehydrogenase isozyme expressed in adult tissues. J Biol Chem 286, 5166-5174

Borghaei H, Paz-Ares L, Horn L, Spigel DR, Steins M, Ready NE, Chow LQ, Vokes EE, Felip E, Holgado E, et al. (2015): Nivolumab versus Docetaxel in Advanced Nonsquamous Non-Small-Cell Lung Cancer. N Engl J Med $\underline{373}$, 16271639

Boroughs LK, Deberardinis RJ (2015): Metabolic pathways promoting cancer cell survival and growth. Nat Cell Biol 17, 351-359

Bray F, Ferlay J, Soerjomataram I, Siegel RL, Torre LA, Jemal A (2018): GLOBOCAN estimates of incidence and mortality worldwide for 36 cancers in 185 countries. CA Cancer J Clin $\underline{68}, 394-424$

Cancer Genome Atlas Research N (2014): Comprehensive molecular profiling of lung adenocarcinoma. Nature $\underline{511}, 543-550$

Chabner BA, Roberts TG (2005): Chemotherapy and the war on cancer. Nat Rev Cancer $\underline{5}, 65-72$

Chattopadhyay S, Moran RG, Goldman ID (2007): Pemetrexed: biochemical and cellular pharmacology, mechanisms, and clinical applications. Mol Cancer Ther $\underline{6}, 404-417$

Chen J, Chung F, Yang G, Pu M, Gao H, Jiang W, Yin H, Capka V, Kasibhatla S, Laffitte B, et al. (2013): Phosphoglycerate dehydrogenase is dispensable for breast tumor maintenance and growth. Oncotarget 4 , 2502-2511

Christensen KE, MacKenzie RE (2006): Mitochondrial one-carbon metabolism is adapted to the specific needs of yeast, plants and mammals. Bioessays $\underline{28}, 595-$ 605 
Christensen KE, Mackenzie RE (2008): Mitochondrial methylenetetrahydrofolate dehydrogenase, methenyltetrahydrofolate cyclohydrolase, and formyltetrahydrofolate synthetases. Vitam Horm $\underline{79}$, 393-410

Cunningham D, Zalcberg J, Smith I, Gore M, Pazdur R, Burris H, Meropol NJ, Kennealey G, Seymour L (1996): a novel thymidylate synthase inhibitor with clinical antitumour activity in a range of solid tumours. Ann Oncol $\underline{7}, 179-182$

Daidone F, Florio R, Rinaldo S, Contestabile R, Salvo ML, Cutruzzola F, Bossa F, Paiardini A (2011): In silico and in vitro validation of serine hydroxymethyltransferase as a chemotherapeutic target of the antifolate drug pemetrexed. Eur J Med Chem 느, 1616-1621

Dasari S, Tchounwou PB (2014): Cisplatin in cancer therapy: molecular mechanisms of action. Eur J Pharmacol $\underline{740}$, 364-378

DeNicola GM, Chen PH, Mullarky E, Sudderth JA, Hu Z, Wu D, Tang H, Xie Y, Asara JM, Huffman KE, et al. (2015): NRF2 regulates serine biosynthesis in nonsmall cell lung cancer. Nat Genet $\underline{47}, 1475-1481$

Ding L, Getz G, Wheeler DA, Mardis ER, McLellan MD, Cibulskis K, Sougnez C, Greulich H, Muzny DM, Morgan MB, et al. (2008): Somatic mutations affect key pathways in lung adenocarcinoma. Nature $\underline{455}$, 1069-1075

Djalalov S, Beca J, Hoch JS, Krahn M, Tsao MS, Cutz JC, Leighl NB (2014): Cost effectiveness of EML4-ALK fusion testing and first-line crizotinib treatment for patients with advanced ALK-positive non-small-cell lung cancer. J Clin Oncol $\underline{32}$, 1012-1019

Dominguez-Salas P, Cox SE, Prentice AM, Hennig BJ, Moore SE (2012): Maternal nutritional status, $C(1)$ metabolism and offspring DNA methylation: a review of current evidence in human subjects. Proc Nutr Soc $\underline{71}, 154-165$

Downward J (2003): Targeting RAS signalling pathways in cancer therapy. Nat Rev Cancer $\underline{3}, 11-22$

Ducker GS, Rabinowitz JD (2017): One-Carbon Metabolism in Health and Disease. Cell Metab 25, 27-42

Ducker GS, Chen L, Morscher RJ, Ghergurovich JM, Esposito M, Teng X, Kang Y, Rabinowitz JD (2016): Reversal of Cytosolic One-Carbon Flux Compensates for Loss of the Mitochondrial Folate Pathway. Cell Metab $\underline{23}$, 1140-1153

Duruisseaux M, Esteller M (2018): Lung cancer epigenetics: From knowledge to applications. Semin Cancer Biol $\underline{51}$, 116-128

Farber S, Diamond LK (1948): Temporary remissions in acute leukemia in children produced by folic acid antagonist, 4-aminopteroyl-glutamic acid. N Engl J Med 238, 787-793 
Fell DA, Snell K (1988): Control analysis of mammalian serine biosynthesis. Feedback inhibition on the final step. Biochem J 256, 97-101

Ferlay J, Colombet M, Soerjomataram I, Mathers C, Parkin DM, Pineros M, Znaor A, Bray $F$ (2019): Estimating the global cancer incidence and mortality in 2018: GLOBOCAN sources and methods. Int J Cancer 144, 1941-1953

Field MS, Kamynina E, Watkins D, Rosenblatt DS, Stover PJ (2015): Human mutations in methylenetetrahydrofolate dehydrogenase 1 impair nuclear de novo thymidylate biosynthesis. Proc Natl Acad Sci USA 112, 400-405

Field MS, Kamynina E, Agunloye OC, Liebenthal RP, Lamarre SG, Brosnan ME, Brosnan JT, Stover PJ (2014): Nuclear enrichment of folate cofactors and methylenetetrahydrofolate dehydrogenase 1 (MTHFD1) protect de novo thymidylate biosynthesis during folate deficiency. J Biol Chem $\underline{289}$, 29642-29650

Gadgeel SM, Ruckdeschel JC, Patel BB, Wozniak A, Konski A, Valdivieso M, Hackstock D, Chen W, Belzer K, Burger AM, et al. (2011): Phase II study of pemetrexed and cisplatin, with chest radiotherapy followed by docetaxel in patients with stage III non-small cell lung cancer. J Thorac Oncol $\underline{6}$, 927-933

Garon EB, Rizvi NA, Hui R, Leighl N, Balmanoukian AS, Eder JP, Patnaik A, Aggarwal C, Gubens M, Horn L, et al. (2015): Pembrolizumab for the treatment of non-small-cell lung cancer. N Engl J Med $\underline{372}$, 2018-2028

George J, Lim JS, Jang SJ, Cun Y, Ozretic L, Kong G, Leenders F, Lu X, Fernandez-Cuesta L, Bosco G, et al. (2015): Comprehensive genomic profiles of small cell lung cancer. Nature $\underline{524}, 47-53$

Gustafsson R, Jemth AS, Gustafsson NM, Farnegardh K, Loseva O, Wiita E, Bonagas N, Dahllund L, Llona-Minguez S, Haggblad M, et al. (2017): Crystal Structure of the Emerging Cancer Target MTHFD2 in Complex with a SubstrateBased Inhibitor. Cancer Res $\underline{77}$, 937-948

Gustafsson Sheppard N, Jarl L, Mahadessian D, Strittmatter L, Schmidt A, Madhusudan N, Tegner J, Lundberg EK, Asplund A, Jain M, et al. (2015): The folate-coupled enzyme MTHFD2 is a nuclear protein and promotes cell proliferation. Sci Rep $\underline{5}, 15029$

Hebbring SJ, Chai Y, Ji Y, Abo RP, Jenkins GD, Fridley B, Zhang J, Eckloff BW, Wieben ED, Weinshilboum RM (2012): Serine hydroxymethyltransferase 1 and 2: gene sequence variation and functional genomic characterization. $J$ Neurochem 120 , 881-890

Herbst RS, Baas P, Kim DW, Felip E, Perez-Gracia JL, Han JY, Molina J, Kim $\mathrm{JH}$, Arvis CD, Ahn MJ, et al. (2016): Pembrolizumab versus docetaxel for previously treated, PD-L1-positive, advanced non-small-cell lung cancer: a randomised controlled trial. Lancet $\underline{387}, 1540-1550$ 
Jain M, Nilsson R, Sharma S, Madhusudhan N, Kitami T, Souza AL, Kafri R, Kirschner MW, Clish CB, Mootha VK (2012): Metabolite profiling identifies a key role for glycine in rapid cancer cell proliferation. Science $\underline{336}, 1040-1044$

Jamieson ER, Lippard SJ (1999): Structure, Recognition, and Processing of Cisplatin-DNA Adducts. Chem Rev $\underline{99}$, 2467-2498

Ju HQ, Lu YX, Wu QN, Liu J, Zeng ZL, Mo HY, Chen Y, Tian T, Wang Y, Kang TB, et al. (2017): Disrupting G6PD-mediated Redox homeostasis enhances chemosensitivity in colorectal cancer. Oncogene $\underline{36}, 6282-6292$

Ju HQ, Lu YX, Chen DL, Zuo ZX, Liu ZX, Wu QN, Mo HY, Wang ZX, Wang DS, Pu HY, et al. (2018): Modulation of Redox Homeostasis by Inhibition of MTHFD2 in Colorectal Cancer. J Natl Cancer Inst $\underline{6}$, 584-596

Kim D, Fiske BP, Birsoy K, Freinkman E, Kami K, Possemato RL, Chudnovsky Y, Pacold ME, Chen WW, Cantor JR, et al. (2015): SHMT2 drives glioma cell survival in ischaemia but imposes a dependence on glycine clearance. Nature $\underline{520}, 363-367$

Koseki J, Konno M, Asai A, Colvin H, Kawamoto K, Nishida N, Sakai D, Kudo T, Satoh T, Doki Y, et al. (2018): Enzymes of the one-carbon folate metabolism as anticancer targets predicted by survival rate analysis. Sci Rep $\underline{8}, 303$

Kris MG, Johnson BE, Berry LD, Kwiatkowski DJ, lafrate AJ, Wistuba, II, VarellaGarcia M, Franklin WA, Aronson SL, Su PF, et al. (2014): Using multiplexed assays of oncogenic drivers in lung cancers to select targeted drugs. Jama $\underline{311}$, 1998-2006

Kruiswijk F, Labuschagne CF, Vousden KH (2015): p53 in survival, death and metabolic health: a lifeguard with a licence to kill. Nat Rev Mol Cell Biol 16, 393405

Lee GY, Haverty PM, Li L, Kljavin NM, Bourgon R, Lee J, Stern H, Modrusan Z, Seshagiri S, Zhang Z, et al. (2014): Comparative oncogenomics identifies PSMB4 and SHMT2 as potential cancer driver genes. Cancer Res $\underline{74}, 3114-3126$

Lehtinen L, Ketola K, Makela R, Mpindi JP, Viitala M, Kallioniemi O, Iljin K (2013): High-throughput RNAi screening for novel modulators of vimentin expression identifies MTHFD2 as a regulator of breast cancer cell migration and invasion. Oncotarget $\underline{4}, 48-63$

Liu F, Liu Y, He C, Tao L, He X, Song H, Zhang G (2014): Increased MTHFD2 expression is associated with poor prognosis in breast cancer. Tumour Biol $\underline{35}$, $8685-8690$

Liu X, Huang Y, Jiang C, Ou H, Guo B, Liao H, Li X, Yang D (2016): Methylenetetrahydrofolate dehydrogenase 2 overexpression is associated with tumor aggressiveness and poor prognosis in hepatocellular carcinoma. Dig Liver Dis $\underline{48}, 953-960$ 
Liu YC, Li F, Handler J, Huang CR, Xiang Y, Neretti N, Sedivy JM, Zeller KI, Dang CV (2008): Global regulation of nucleotide biosynthetic genes by c-Myc. PLoS One $\underline{3}, 2722$

Locasale JW (2013): Serine, glycine and one-carbon units: cancer metabolism in full circle. Nat Rev Cancer $\underline{13}, 572-583$

Locasale JW, Grassian AR, Melman T, Lyssiotis CA, Mattaini KR, Bass AJ, Heffron G, Metallo CM, Muranen T, Sharfi H, et al. (2011): Phosphoglycerate dehydrogenase diverts glycolytic flux and contributes to oncogenesis. Nat Genet $\underline{43}, 869-874$

Longley DB, Harkin DP, Johnston PG (2003): 5-fluorouracil: mechanisms of action and clinical strategies. Nat Rev Cancer $\underline{3}, 330-338$

Maddocks OD, Berkers CR, Mason SM, Zheng L, Blyth K, Gottlieb E, Vousden $\mathrm{KH}$ (2013): Serine starvation induces stress and p53-dependent metabolic remodelling in cancer cells. Nature $\underline{493}, 542-546$

Marx A, Chan JK, Coindre JM, Detterbeck F, Girard N, Harris NL, Jaffe ES, Kurrer MO, Marom EM, Moreira AL, et al. (2015): The 2015 World Health Organization Classification of Tumors of the Thymus: Continuity and Changes. J Thorac Oncol $\underline{10}, 1383-1395$

Mehrmohamadi M, Liu X, Shestov AA, Locasale JW (2014): Characterization of the usage of the serine metabolic network in human cancer. Cell Rep $\underline{9}, 1507-$ 1519

Minton DR, Nam M, McLaughlin DJ, Shin J, Bayraktar EC, Alvarez SW, Sviderskiy VO, Papagiannakopoulos T, Sabatini DM, Birsoy K, et al. (2018): Serine Catabolism by SHMT2 Is Required for Proper Mitochondrial Translation Initiation and Maintenance of Formylmethionyl-tRNAs. Mol Cell $\underline{69}$, 610-621

Miyo M, Konno M, Colvin H, Nishida N, Koseki J, Kawamoto K, Tsunekuni K, Nishimura J, Hata T, Takemasa I, et al. (2017): The importance of mitochondrial folate enzymes in human colorectal cancer. Oncol Rep $\underline{37}, 417-425$

Mok TS, Wu YL, Thongprasert S, Yang CH, Chu DT, Saijo N, Sunpaweravong P, Han B, Margono B, Ichinose Y, et al. (2009): Gefitinib or carboplatin-paclitaxel in pulmonary adenocarcinoma. N Engl J Med 361, 947-957

Moran DM, Trusk PB, Pry K, Paz K, Sidransky D, Bacus SS (2014): KRAS mutation status is associated with enhanced dependency on folate metabolism pathways in non-small cell lung cancer cells. Mol Cancer Ther $\underline{13}, 1611-1624$

Morgensztern D, Du L, Waqar SN, Patel A, Samson P, Devarakonda S, Gao F, Robinson CG, Bradley J, Baggstrom M, et al. (2016): Adjuvant Chemotherapy for Patients with T2NOMO NSCLC. J Thorac Oncol 11, 1729-1735 
Mullarky E, Mattaini KR, Vander Heiden MG, Cantley LC, Locasale JW (2011): PHGDH amplification and altered glucose metabolism in human melanoma. Pigment Cell Melanoma Res 24, 1112-1115

Mullarky E, Lucki NC, Beheshti Zavareh R, Anglin JL, Gomes AP, Nicolay BN, Wong JC, Christen S, Takahashi H, Singh PK, et al. (2016): Identification of a small molecule inhibitor of 3-phosphoglycerate dehydrogenase to target serine biosynthesis in cancers. Proc Natl Acad Sci USA 113, 1778-1783

Nakaoku T, Tsuta K, Ichikawa H, Shiraishi K, Sakamoto H, Enari M, Furuta K, Shimada Y, Ogiwara H, Watanabe S, et al. (2014): Druggable oncogene fusions in invasive mucinous lung adenocarcinoma. Clin Cancer Res $\underline{20}$, 3087-3093

Newman AC, Maddocks ODK (2017): One-carbon metabolism in cancer. Br J Cancer $\underline{116}, 1499-1504$

Nilsson R, Jain M, Madhusudhan N, Sheppard NG, Strittmatter L, Kampf C, Huang J, Asplund A, Mootha VK (2014): Metabolic enzyme expression highlights a key role for MTHFD2 and the mitochondrial folate pathway in cancer. Nat Commun $\underline{5}, 3128$

Nishimura T, Nakata A, Chen X, Nishi K, Meguro-Horike M, Sasaki S, Kita K, Horike SI, Saitoh K, Kato K, et al. (2019): Cancer stem-like properties and gefitinib resistance are dependent on purine synthetic metabolism mediated by the mitochondrial enzyme MTHFD2. Oncogene $\underline{38}, 2464-2481$

Nizzoli R, Tiseo M, Gelsomino F, Bartolotti M, Majori M, Ferrari L, De Filippo M, Rindi G, Silini EM, Guazzi A, et al. (2011): Accuracy of fine needle aspiration cytology in the pathological typing of non-small cell lung cancer. J Thorac Oncol 6, 489-493

Noguchi K, Konno M, Koseki J, Nishida N, Kawamoto K, Yamada D, Asaoka T, Noda T, Wada H, Gotoh K, et al. (2018): The mitochondrial one-carbon metabolic pathway is associated with patient survival in pancreatic cancer. Oncol Lett $\underline{16}$, 1827-1834

Okamoto $H$, Watanabe K, Kunikane H, Yokoyama A, Kudoh S, Asakawa T, Shibata T, Kunitoh H, Tamura T, Saijo N (2007): Randomised phase III trial of carboplatin plus etoposide vs split doses of cisplatin plus etoposide in elderly or poor-risk patients with extensive disease small-cell lung cancer: JCOG 9702. Br J Cancer $\underline{97}, 162-169$

Pacold ME, Brimacombe KR, Chan SH, Rohde JM, Lewis CA, Swier LJ, Possemato R, Chen WW, Sullivan LB, Fiske BP, et al. (2016): A PHGDH inhibitor reveals coordination of serine synthesis and one-carbon unit fate. Nat Chem Biol $\underline{12}, 452-458$

Paez JG, Janne PA, Lee JC, Tracy S, Greulich H, Gabriel S, Herman P, Kaye FJ, Lindeman N, Boggon TJ, et al. (2004): EGFR mutations in lung cancer: correlation with clinical response to gefitinib therapy. Science $\underline{304}, 1497-1500$ 
Paz-Ares L, de Marinis F, Dediu M, Thomas M, Pujol JL, Bidoli P, Molinier O, Sahoo TP, Laack E, Reck M, et al. (2012): Maintenance therapy with pemetrexed plus best supportive care versus placebo plus best supportive care after induction therapy with pemetrexed plus cisplatin for advanced non-squamous non-smallcell lung cancer: a double-blind, phase 3, randomised controlled trial. Lancet Oncol $\underline{13}, 247-255$

Paz-Ares LG, de Marinis F, Dediu M, Thomas M, Pujol JL, Bidoli P, Molinier O, Sahoo TP, Laack E, Reck M, et al. (2013): Final overall survival results of the phase III study of maintenance pemetrexed versus placebo immediately after induction treatment with pemetrexed plus cisplatin for advanced nonsquamous non-small-cell lung cancer. J Clin Oncol $\underline{31}$, 2895-2902

Pelengaris S, Littlewood T, Khan M, Elia G, Evan G (1999): Reversible activation of c-Myc in skin: induction of a complex neoplastic phenotype by a single oncogenic lesion. Mol Cell $\underline{3}, 565-577$

Pikman Y, Puissant A, Alexe G, Furman A, Chen LM, Frumm SM, Ross L, Fenouille N, Bassil CF, Lewis CA, et al. (2016): Targeting MTHFD2 in acute myeloid leukemia. J Exp Med 213, 1285-1306

Piskounova E, Agathocleous M, Murphy MM, Hu Z, Huddlestun SE, Zhao Z, Leitch AM, Johnson TM, DeBerardinis RJ, Morrison SJ (2015): Oxidative stress inhibits distant metastasis by human melanoma cells. Nature $\underline{527}, 186-191$

Politi K, Herbst RS (2015): Lung cancer in the era of precision medicine. Clin Cancer Res 21, 2213-2220

Possemato R, Marks KM, Shaul YD, Pacold ME, Kim D, Birsoy K, Sethumadhavan S, Woo HK, Jang HG, Jha AK, et al. (2011): Functional genomics reveal that the serine synthesis pathway is essential in breast cancer. Nature $\underline{476}, 346-350$

Reck M, Rodriguez-Abreu D, Robinson AG, Hui R, Csoszi T, Fulop A, Gottfried M, Peled N, Tafreshi A, Cuffe S, et al. (2016): Pembrolizumab versus Chemotherapy for PD-L1-Positive Non-Small-Cell Lung Cancer. N Engl J Med $\underline{375}, 1823-1833$

Rekhtman N, Brandt SM, Sigel CS, Friedlander MA, Riely GJ, Travis WD, Zakowski MF, Moreira AL (2011): Suitability of thoracic cytology for new therapeutic paradigms in non-small cell lung carcinoma: high accuracy of tumor subtyping and feasibility of EGFR and KRAS molecular testing. J Thorac Oncol $\underline{6}, 451-458$

Salazar MC, Rosen JE, Wang Z, Arnold BN, Thomas DC, Herbst RS, Kim AW, Detterbeck FC, Blasberg JD, Boffa DJ (2017): Association of Delayed Adjuvant Chemotherapy With Survival After Lung Cancer Surgery. JAMA Oncol $\underline{3}, 610-$ 619

Samanta D, Park Y, Andrabi SA, Shelton LM, Gilkes DM, Semenza GL (2016): PHGDH Expression Is Required for Mitochondrial Redox Homeostasis, Breast 
Cancer Stem Cell Maintenance, and Lung Metastasis. Cancer Res $\underline{76}, 4430-$ 4442

Sandler A, Gray R, Perry MC, Brahmer J, Schiller JH, Dowlati A, Lilenbaum R, Johnson DH (2006): Paclitaxel-carboplatin alone or with bevacizumab for nonsmall-cell lung cancer. N Engl J Med 355, 2542-2550

Scagliotti GV, Gridelli C, de Marinis F, Thomas M, Dediu M, Pujol JL, Manegold C, San Antonio B, Peterson PM, John W, et al. (2014): Efficacy and safety of maintenance pemetrexed in patients with advanced nonsquamous non-small cell lung cancer following pemetrexed plus cisplatin induction treatment: A cross-trial comparison of two phase III trials. Lung Cancer $\underline{85}$, 408-414

Scagliotti GV, Parikh P, von Pawel J, Biesma B, Vansteenkiste J, Manegold C, Serwatowski P, Gatzemeier U, Digumarti R, Zukin M, et al. (2008): Phase III study comparing cisplatin plus gemcitabine with cisplatin plus pemetrexed in chemotherapy-naive patients with advanced-stage non-small-cell lung cancer. $\mathrm{J}$ Clin Oncol 26, 3543-3551

Schiller JH, Harrington D, Belani CP, Langer C, Sandler A, Krook J, Zhu J, Johnson DH (2002): Comparison of four chemotherapy regimens for advanced non-small-cell lung cancer. N Engl J Med 346, 92-98

Sen N, Cross AM, Lorenzi PL, Khan J, Gryder BE, Kim S, Caplen NJ (2018): EWS-FLI1 reprograms the metabolism of Ewing sarcoma cells via positive regulation of glutamine import and serine-glycine biosynthesis. Mol Carcinog $\underline{57}$, 1342-1357

Shane B, Stokstad EL (1985): Vitamin B12-folate interrelationships. Annu Rev Nutr $\underline{5}, 115-141$

Shchors K, Shchors E, Rostker F, Lawlor ER, Brown-Swigart L, Evan GI (2006): The Myc-dependent angiogenic switch in tumors is mediated by interleukin 1 beta. Genes Dev 20, 2527-2538

Shih C, Chen VJ, Gossett LS, Gates SB, MacKellar WC, Habeck LL, Shackelford KA, Mendelsohn LG, Soose DJ, Patel VF, et al. (1997): LY231514, a pyrrolo[2,3d]pyrimidine-based antifolate that inhibits multiple folate-requiring enzymes. Cancer Res $\underline{57}, 1116-1123$

Shim HS, Kenudson M, Zheng Z, Liebers M, Cha YJ, Hoang Ho Q, Onozato M, Phi Le L, Heist RS, lafrate AJ (2015): Unique Genetic and Survival Characteristics of Invasive Mucinous Adenocarcinoma of the Lung. J Thorac Oncol $\underline{10}, 1156-1162$

Siegel RL, Miller KD, Jemal A (2018): Cancer statistics, 2018. CA Cancer J Clin 68, 7-30

Siegel RL, Miller KD, Jemal A (2019): Cancer statistics, 2019. CA Cancer J Clin $\underline{69}, 7-34$ 
Skoulidis F, Heymach JV (2019): Co-occurring genomic alterations in non-smallcell lung cancer biology and therapy. Nat Rev Cancer $\underline{19}$, 495-509

Smith PG, Marshman E, Newell DR, Curtin NJ (2000): Dipyridamole potentiates the in vitro activity of MTA (LY231514) by inhibition of thymidine transport. $\mathrm{Br} J$ Cancer 82, 924-930

Snell K (1984): Enzymes of serine metabolism in normal, developing and neoplastic rat tissues. Adv Enzyme Regul 22, 325-400

Snell K, Weber G (1986): Enzymic imbalance in serine metabolism in rat hepatomas. Biochem J $\underline{233}, 617-620$

Snell K, Natsumeda Y, Weber G (1987): The modulation of serine metabolism in hepatoma 3924A during different phases of cellular proliferation in culture. Biochem J 245, 609-612

Song Z, Feng C, Lu Y, Lin Y, Dong C (2018): PHGDH is an independent prognosis marker and contributes cell proliferation, migration and invasion in human pancreatic cancer. Gene $\underline{642}, 43-50$

Stipanuk MH (2004): Sulfur amino acid metabolism: pathways for production and removal of homocysteine and cysteine. Annu Rev Nutr 24, 539-577

Stover P, Schirch V (1990): Serine hydroxymethyltransferase catalyzes the hydrolysis of 5,10-methenyltetrahydrofolate to 5-formyltetrahydrofolate. J Biol Chem $\underline{265}, 14227-14233$

Stover PJ (2004): Physiology of folate and vitamin B12 in health and disease. Nutr Rev $\underline{62}, 3-12$

Takada M, Fukuoka M, Kawahara M, Sugiura T, Yokoyama A, Yokota S, Nishiwaki Y, Watanabe K, Noda K, Tamura T, et al. (2002): Phase III study of concurrent versus sequential thoracic radiotherapy in combination with cisplatin and etoposide for limited-stage small-cell lung cancer. J Clin Oncol $\underline{20}$, 30543060

Takeuchi K, Soda M, Togashi Y, Suzuki R, Sakata S, Hatano S, Asaka R, Hamanaka W, Ninomiya H, Uehara H, et al. (2012): RET, ROS1 and ALK fusions in lung cancer. Nat Med $\underline{18}, 378-381$

Tedeschi PM, Vazquez A, Kerrigan JE, Bertino JR (2015): Mitochondrial Methylenetetrahydrofolate Dehydrogenase (MTHFD2) Overexpression Is Associated with Tumor Cell Proliferation and Is a Novel Target for Drug Development. Mol Cancer Res $\underline{13}$, 1361-1366

Tibbetts AS, Appling DR (2010): Compartmentalization of Mammalian folatemediated one-carbon metabolism. Annu Rev Nutr 30, 57-81

Travis WD, Brambilla E, Nicholson AG, Yatabe Y, Austin JHM, Beasley MB, Chirieac LR, Dacic S, Duhig E, Flieder DB, et al. (2015): Impact of Genetic, 
Clinical and Radiologic Advances Since the 2004 Classification. J Thorac Oncol 10, $1243-1260$

Vander Heiden MG (2011): Targeting cancer metabolism: a therapeutic window opens. Nat Rev Drug Discov 10, 671-684

Vansteenkiste J, Crino L, Dooms C, Douillard JY, Faivre-Finn C, Lim E, Rocco G, Senan S, Van Schil P, Veronesi G, et al. (2014): early-stage non-small-cell lung cancer consensus on diagnosis, treatment and follow-up. Ann Oncol $\underline{25}$, 14621474

Wang X, Yang K, Xie Q, Wu Q, Mack SC, Shi Y, Kim LJY, Prager BC, Flavahan WA, Liu X, et al. (2017): Purine synthesis promotes maintenance of brain tumor initiating cells in glioma. Nat Neurosci $\underline{20}, 661-673$

Wei Y, Liu P, Li Q, Du J, Chen Y, Wang Y, Shi H, Wang Y, Zhang H, Xue W, et al. (2019): The effect of MTHFD2 on the proliferation and migration of colorectal cancer cell lines. Onco Targets Ther 12, 6361-6370

Williams EA (2012): Folate, colorectal cancer and the involvement of DNA methylation. Proc Nutr Soc 71, 592-597

Wisniewski JR, Mann M (2016): A Proteomics Approach to the Protein Normalization Problem: Selection of Unvarying Proteins for MS-Based Proteomics and Western Blotting. J Proteome Res 15, 2321-2326

Woo CC, Chen WC, Teo XQ, Radda GK, Lee PT (2016): Downregulating serine hydroxymethyltransferase 2 (SHMT2) suppresses tumorigenesis in human hepatocellular carcinoma. Oncotarget $\underline{7}, 53005-53017$

Yang M, Vousden KH (2016): Serine and one-carbon metabolism in cancer. Nat Rev Cancer 16, 650-662

Yoshino H, Nohata N, Miyamoto K, Yonemori M, Sakaguchi T, Sugita S, Itesako T, Kofuji S, Nakagawa M, Dahiya R, et al. (2017): PHGDH as a Key Enzyme for Serine Biosynthesis in HIF2alpha-Targeting Therapy for Renal Cell Carcinoma. Cancer Res $\underline{77}$, 6321-6329

Zamble DB, Lippard SJ (1995): Cisplatin and DNA repair in cancer chemotherapy. Trends Biochem Sci 20, 435-439

Zhang B, Zheng A, Hydbring P, Ambroise G, Ouchida AT, Goiny M, Vakifahmetoglu-Norberg H, Norberg E (2017): PHGDH Defines a Metabolic Subtype in Lung Adenocarcinomas with Poor Prognosis. Cell Rep 19, 2289-2303

Zhang L, Chen Z, Xue D, Zhang Q, Liu X, Luh F, Hong L, Zhang H, Pan F, Liu Y, et al. (2016): Prognostic and therapeutic value of mitochondrial serine hydroxylmethyltransferase 2 as a breast cancer biomarker. Oncol Rep 36, 2489-2500 
Zhang WC, Shyh-Chang N, Yang H, Rai A, Umashankar S, Ma S, Soh BS, Sun LL, Tai BC, Nga ME, et al. (2012): Glycine decarboxylase activity drives nonsmall cell lung cancer tumor-initiating cells and tumorigenesis. Cell 148, 259-272 


\section{Publications}

Saha S, Yao S, Elakad O, Lois AM, Petri HH, Buentzel J, Hinterthaner M, Danner BC, Ströbel P, Emmert A, et al. (2020): UDP-glucose 6-dehydrogenase expression as a predictor of survival in patients with pulmonary adenocarcinoma. IJS Oncol 5, 85 (shared first authorship)

Buentzel J, Yao S, Elakad O, Lois AM, Brunies J, Konig J, Hinterthaner M, Danner BC, Ströbel P, Emmert A, et al. (2019): Expression and prognostic impact of alpha thalassemia/mental retardation X-linked and death domainassociated protein in human lung cancer. Medicine 98, 16712 (shared first authorship)

Bohnenberger H, Kaderali L, Ströbel P, Yepes D, Plessmann U, Dharia NV, Yao S, Heydt C, Merkelbach-Bruse S, Emmert A, et al. (2018): Comparative proteomics reveals a diagnostic signature for pulmonary head-and-neck cancer metastasis. EMBO Mol Med 10, 8428

Elakad O, Lois AM, Schmitz K, Yao S, Hugo S, Lukat L, Hinterthaner M, Danner BC, Emmert A, Jessen KR, et al. (2020): Fibroblast growth factor receptor 1 gene amplification and protein expression in human lung cancer. Cancer Med $\underline{10}$, 3574-3583 


\section{Acknowledgements}

First of all, I would like to express my heartfelt thanks to Prof. Dr. med. Philipp Ströbel and Prof. Dr. med. Volker Ellenrieder, for supervising my doctoral work.

Secondly, my profound gratitude should go to Dr. med Hanibal Bohnenberger, for provision of topic of the thesis and the thorough and educational guidance through my doctoral work. He has given me not only great instructions and encouragements throughout the process of performing experiments and writing the thesis but also plenty of help in student registration and life. I could not have finished my doctoral work and thesis without his patient guidance and help.

I also want to thank Dr. sc. hum. Stefan Küffer, Ms. Pamela Nissen and Ms. Jenny Appelhans, for fruitful discussions and technical assistance.

Thanks Chinese Scholarship Council for supporting me to pursue my doctoral diploma and providing funding. 